\title{
Site U1402
}

R.D. Norris, P.A. Wilson, P. Blum, A. Fehr, C. Agnini, A. Bornemann, S. Boulila, P.R. Bown, C. Cournede, O. Friedrich, A.K. Ghosh, C.J. Hollis, P.M. Hull, K. Jo, C.K. Junium, M. Kaneko, D. Liebrand, P.C. Lippert, Z. Liu, H. Matsui, K. Moriya, H. Nishi, B.N. Opdyke, D. Penman, B. Romans, H.D. Scher, P. Sexton, H. Takagi, S.K. Turner, J.H. Whiteside, T. Yamaguchi, and Y. Yamamoto ${ }^{2}$

\section{Chapter contents}

Background and objectives..........

Operations..................

Lithostratigraphy..............

Biostratigraphy .................

Paleomagnetism ...............4

Geochemistry ................

Physical properties ............6 6

MDHDS deployment............. 7

References.................. 13

Figures................. 14

Tables........................ 55

${ }^{1}$ Norris, R.D., Wilson, P.A., Blum, P., Fehr, A., Agnini, C., Bornemann, A., Boulila, S., Bown, P.R., Cournede, C., Friedrich, O., Ghosh, A.K., Hollis, C.J., Hull, P.M., Jo, K., Junium, C.K., Kaneko, M., Liebrand, D., Lippert, P.C., Liu, Z., Matsui, H., Moriya, K., Nishi, H., Opdyke, B.N., Penman, D., Romans, B., Scher, H.D., Sexton, P., Takagi, H., Turner, S.K., Whiteside, J.H., Yamaguchi, T., and Yamamoto, Y., 2014. Site U1402. In Norris, R.D., Wilson, P.A., Blum, P., and the Expedition 342 Scientists, Proc. IODP, 342: College Station, TX (Integrated Ocean Drilling Program). doi:10.2204/iodp.proc.342.103.2014

'Expedition 342 Scientists' addresses.

\section{Background and objectives}

Integrated Ocean Drilling Program (IODP) Site U1402 was chosen as the location for the engineering test of the Motion Decoupled Hydraulic Delivery System (MDHDS). The MDHDS is a new downhole tool delivery system that is deployed by wireline and uses drill string pressure to advance a penetrometer (or other downhole tool) into the formation at the bottom of the borehole. After hydraulic deployment of the penetrometer, the bottom-hole assembly (BHA) is completely decoupled from the BHA; this eliminates the adverse effects of ship heave. The motivation for this engineering development is discussed by Flemings et al. (in press) and in "Background and Objectives: Motion Decoupled Hydraulic Delivery System sea trials" in the "Expedition 342 summary" chapter (Norris et al., 2014a).

Site U1402 is at the same location as Ocean Drilling Program (ODP) Leg 174A Site 1073 (Fig. F1). At this location, the continental slope is smooth and draped by sediments from the Hudson apron, and the water depth is $639 \mathrm{~m}$. During Leg 174A, advanced piston corer (APC) cores were taken to $215 \mathrm{~m}$ below seafloor (mbsf). Sediments within the uppermost 200 mbsf were dominated by silty clay (Shipboard Scientific Party, 1998).

The former Site 1073 was chosen because the lithology was well understood from previous drilling (Fig. F2). The mudstone lithology was known to be appropriate for deployment of a penetrometer. Finally, previous work had inferred the presence of excess pressures in this location (Dugan and Flemings, 2000) (Fig. F2), and thus a scientific goal was to directly document the presence of overpressures.

Approximately 2 days of ship time were dedicated to testing the MDHDS. When time allowed, some piston cores were also taken.

\section{Operations}

All times shown are local ship time (Universal Time Coordinated $-3 \mathrm{~h})$.

\section{Hole U1402A summary}

Latitude: $39^{\circ} 13.518^{\prime} \mathrm{N}$

Longitude: $72^{\circ} 16.5488^{\prime} \mathrm{W}$

Water depth (m): 638.6 
Date started: 1542 h, 6 June 2012

Date finished: 0110 h, 8 June 2012

Time on hole (days): 1.4

Seafloor depth below rig floor ( $m$ drilling depth below rig floor [DRF]): 650.5

Seafloor depth estimation method: previous drilling at Site 1073

Rig floor to sea level (m): 11.4

Penetration depth below seafloor ( $m$ drilling depth below seafloor [DSF]): 96.4

Cored interval (m): none

Drilled interval (m): 96.4

Drilling system: 117/16 inch APC/extended core barrel (XCB) bit with $126.58 \mathrm{~m} \mathrm{BHA}$

Objective: wash down to 100 mbsf and begin engineering test of MDHDS and temperature-dualpressure probe (T2P) tools. Spot core per instructions.

Result: initial trip and the in-pipe test of the electronic RS (ERS; "RS" is an oil-field designation for a particular geometry of fishing tool), MDHDS, and T2P tool was aborted when the tool prematurely released at $250 \mathrm{~m}$ DRF. After trying to reattach the ERS and trying to fish the assembly, the drill string was tripped to the surface and the test equipment was rigged down and tested. The second test was partially successful and required another trip out of the hole.

\section{Hole U1402B summary}

Latitude: $39^{\circ} 13.518^{\prime} \mathrm{N}$

Longitude: $72^{\circ} 16.535^{\prime} \mathrm{W}$

Water depth (m): 639.1

Date started: 0110 h, 8 June 2012

Date finished: 1330 h, 8 June 2012

Time on hole (days): 0.5

Seafloor depth below rig floor (m DRF): 650.5

Seafloor depth estimated method: APC-calculated depth

Rig floor to sea level (m): 11.4

Penetration depth below sea floor (m DSF): 15

Cored interval (m): 15

Recovered length (m): 15.05

Recovery (\%): 100

Drilled interval $(\mathrm{m})$ : none

Drilling system: 117/16 inch APC/XCB bit with $126.58 \mathrm{~m} \mathrm{BHA}$

Objective: core until time expires at Site U1402.

Result: recovered Cores 342-U1402B-1H through $2 \mathrm{H}$.

\section{Description}

After a $582 \mathrm{nmi}$ transit from Bermuda to Site U1402 averaging $10.1 \mathrm{kt}$, the vessel arrived at the first expe- dition location to perform engineering qualification tests on the MDHDS. The vessel was at Site U1402 at $1542 \mathrm{~h}$ on 6 June 2012.

The BHA was picked up and drifted, and the drill pipe was lowered to $608 \mathrm{~m}$ DRF and circulated out to remove any debris. The MDHDS with the temperature-dual-pressure probe (T2P) was made up for deployment using the developmentalERS on Schlumberger wireline. After running the tools through the blocks, a surface test was performed to check all components prior to deployment. A communication problem with the tool was fixed, and the Schlumberger wireline was run into the drill pipe to $\sim 250 \mathrm{~m}$ DRF. At that point, the ERS released prematurely, allowing the MDHDS and T2P to fall $400 \mathrm{~m}$ to the landing seat in the BHA. An attempt was made to reattach the ERS to the MDHDS, without success, and the Schlumberger wireline was pulled from the drill pipe. An MDHDS mechanical latch assembly with sinker bars was assembled and deployed on the coring line in an attempt to fish the MDHDS tool, without success. Upon retrieval of the coring line, the sinker bars were observed to have parted from the retrieval sub overshot, leaving a configuration that was impossible to fish. The decision was made to pull the drill string out of the hole to retrieve the test equipment inside the BHA.

At $0800 \mathrm{~h}$, the M/V North Star arrived on location and was secured to the port side of the R/V JOIDES Resolution within reach of the number 3 crane. Three pallets of provisions and a pallet of severing explosives were unloaded from the North Star, which was released and cleared of the JOIDES Resolution at $0828 \mathrm{~h}$.

After tripping out of the hole, the test equipment was removed from the BHA and inspected for damage. The drill string was again deployed, and Hole U1402A was spudded at $1405 \mathrm{~h}$ on 7 June, with the seafloor recorded at $650 \mathrm{~m}$ DRF. Hole U1402A was washed down to $96.4 \mathrm{~m}$ DSF (746.4 $\mathrm{m} \mathrm{DRF),} \mathrm{and} \mathrm{the}$ MDHDS, T2P, and ERS were assembled and deployed for a second test. Both temperature and pressure signals were successfully transmitted to the rig floor for $\sim 30 \mathrm{~min}$ and recorded. When circulation was reestablished to test the effects of circulation on formation pore pressure, telemetry was lost. It was found that the tool could not be withdrawn using the wireline system. The ERS was released, the Schlumberger wireline was pulled from the hole, the top drive was set back, and the drill string was tripped from the hole. The bit cleared the rotary table at $0110 \mathrm{~h}$ on 8 June, ending Hole U1402A. It was found that the tether within the MDHDS had worked between the tool and the inside of the BHA aperture, jamming the tool in place and preventing recovery. This concluded the MDHDS sea trial. 
When the MDHDS tests were concluded, several hours remained until a helicopter would arrive to exchange departing engineers with arriving science support technicians. The science party requested that a few cores be obtained from Site U1402 to test lab equipment and provide experience for the science staff. The vessel was offset $20 \mathrm{~m}$ east, the drill string was deployed a third time, and Hole U1402B was spudded at $0625 \mathrm{~h}$ on 8 June. Two cores were taken from 0-15 m DSF, with 100\% recovery (Table T1). Core 342-U1402B-1H was a $7 \mathrm{~m}$ long mudline core, and Core $2 \mathrm{H}$ was an $8 \mathrm{~m}$ long partial stroke core that suffered significant core liner damage. The coring system had to be disassembled to remove the core and liner and was reassembled.

While working on retrieving the second core, a scheduled helicopter arrived on deck at $0932 \mathrm{~h}$ with four United States Implementing Organization (USIO) staff. The helicopter refueled, took on five MDHDS scientists/engineers and luggage, and departed the JOIDES Resolution at $1020 \mathrm{~h}$. The rig floor was secured at $1330 \mathrm{~h}$ on 8 June, ending Hole $\mathrm{U} 1402 \mathrm{~B}$, and the vessel was under way at full speed to Site U1403.

\section{Lithostratigraphy}

Drilling in Hole U1402B, a reoccupation of Site 1073, recovered $15.05 \mathrm{~m}$ of hemipelagic sediment from the New Jersey margin following the engineering test of the MDHDS performed in Hole U1402A. The $15.05 \mathrm{~m}$ thick sequence is composed of two cores of Pleistocene age (Fig. F3). On the basis of visual core descriptions and smear slide analyses, the recovered section comprises one lithostratigraphic unit of silty clay. These findings are consistent with results from the uppermost cores at Site 1073.

\section{Unit I}

Interval: 342-U1402B-1H-1, $0 \mathrm{~cm}$, through 2H-CC, $82 \mathrm{~cm}$

Depth: Hole U1402B $=0.0-15.05$ mbsf

Age: Pleistocene

Lithology: silty clay

Unit I is a dark grayish brown (10YR 4/2) homogeneous silty clay with subtle greenish gray and black monosulfide mottling. At $1.90 \mathrm{mbsf}$, we note a change in color from dark greenish gray (10Y 4/1) to dark gray (N 4/1) homogeneous silty clay with common black monosulfide mottling (Fig. F4). Smear slide analyses reveal angular quartz (silt and sand sized), feldspar silt, monosulfides, mica silt, and calcareous nannofossils as minor lithologic components ( $<5 \%$ abundance).

\section{Biostratigraphy}

Coring in Hole U1402B recovered a $15 \mathrm{~m}$ thick sequence of Holocene-Pleistocene dark gray silty clay. Calcareous nannofossils are few, moderately well preserved, and age diagnostic. Planktonic foraminifers are rare and well preserved but largely comprise long-ranging taxa. Benthic foraminifers are rare and well preserved and indicate an upper bathyal depth. Radiolarians are very rare.

\section{Calcareous nannofossils}

Calcareous nannofossil biostratigraphy is based on analysis of both core catcher samples from Hole U1402B (Samples 342-U1402B-1H-CC and 2H-CC). Nannofossils are few, exhibit low diversity, and are diluted by abundant clay and silt particles. The samples contain common Emiliania huxleyi and can be assigned to upper nannofossil Zone NN21, within the E. huxleyi acme interval $(<0.7 \mathrm{Ma})$. Rare Cretaceous and Eocene reworked specimens are present.

\section{Radiolarians}

Radiolarians are very rare in the examined cores. One sample (342-U1402B-1H-CC) was barren and the other sample (2H-CC) contained only two specimens, one specimen of Actinomma leptodernum Jorgensen and one specimen of Lithelius minor group Jorgensen. A. leptodernum is an extant species that appears to be restricted to the late Quaternary (radiolarian Zone RN17; <0.18 Ma) (Bjørklund, 1976; Nigrini and Moore, 1979). L. minor group ranges from Late Cretaceous to recent (Hollis, 1997).

\section{Planktonic foraminifers}

Planktonic foraminifer biostratigraphy is based on analysis of both core catcher samples in Hole U1402B. The samples contain many sedimentary grains (quartz and sulfide) and micaceous particles, but planktonic foraminifers are rare. The preservation of planktonic foraminifers is generally good to excellent.

In Sample 342-U1402B-1H-CC, the faunal assemblage includes Globigerinoides ruber (pink), G. ruber (white), Globorotalia (Globoconella) inflata, Neogloboquadrina pachyderma, Neogloboquadrina incompta, Globigerina bulloides, and Globigerina quinqueloba. Some warm-water specimens of Globigerinoides sacculifer and Globigerinoides pyramidalis are also present. G. ruber (pink) is commonly found in tropical Pleistocene assemblages.

In Sample 342-U1402B-2H-CC, planktonic foraminifers are rare, but preservation is good. Specimens of G. bulloides, N. pachyderma, N. incompta, G. quinque- 
loba, and Orbulina universa were recovered. The assemblage appears to be similar in age (Pleistocene) to Sample 1H-CC.

\section{Benthic foraminifers}

Benthic foraminifers were examined semiquantitatively in core catchers 342-U1402B-1H-CC and $2 \mathrm{H}-$ CC. Benthic foraminifers in this hole are rare relative to total sediment particles. Preservation of foraminifer tests was generally very good except for some possibly reworked specimens showing moderate to poor preservation. The occurrence of benthic foraminifers at this site is shown in Table T2.

In Sample 342-U1402B-1H-CC (6.97 mbsf), both Islandiella australis and Cassidulina minuta are dominant, and Melonis affinis, Nonionellina labradorica, and Nonionellina turgica are subordinate. The presence of Praeglobobulimina ovata might indicate a slightly suboxic environment. In addition to these well-preserved specimens, a few poorly preserved nonionid specimens are present. Overall, the assemblage indicates an upper bathyal paleodepth.

Sample 342-U1402B-2H-CC (14.24 mbsf) predominantly yields $I$. australis. A few C. minuta, rare N. labradorica, and Quinqueloculina sp. are also present. The very low diversity and occurrence of some Stainforthia specimens might indicate a suboxic environment. Preservation of foraminiferal tests is generally very good, with the exception of a few possibly reworked nonionid specimens. The assemblage also indicates an upper bathyal paleodepth.

\section{Paleomagnetism}

We completed a preliminary paleomagnetism study of the two APC cores in Hole U1402B with the primary objective of establishing a magnetostratigraphy of the site to provide chronostratigraphic age control. The natural remanent magnetization (NRM) of each archive section half was measured at $2.5 \mathrm{~cm}$ intervals before and after demagnetization treatment in a peak alternating field (AF) of $20 \mathrm{mT}$. NRM measurement on the archive half of Section 342U1402B-1H-1 was not conducted (not intentionally). Two sections, $1 \mathrm{H}-3$ and $1 \mathrm{H}-4$, were not measured because they were not split. We processed the data by removing measurements made within $7.5 \mathrm{~cm}$ of section ends and from disturbed intervals as described in the Laboratory Information Management System (LIMS) database.

Reversal patterns can be easily determined at the site latitude $\left(\sim 40^{\circ} \mathrm{N}\right)$ by changes in inclination polarity. When cores are azimuthally oriented, north- and south-directed declinations can clarify magnetic po- larity. Cores at Site U1402, however, were not oriented because the FlexIT tool was not used during coring.

Eight discrete samples, taken in plastic NatsuharaGiken sampling cubes, were collected from working section halves. Samples were typically taken from the least disturbed region closest to the center of each section. The samples were first subjected to measurements of the anisotropy of magnetic susceptibility (AMS), including bulk susceptibility. Subsequently, the samples were step-wise AF demagnetized at 10 and $20 \mathrm{mT}$. Three of the samples were further demagnetized at 30, 40,60, and $80 \mathrm{mT}$. All discrete sample data were volume corrected to $7 \mathrm{~cm}^{3}$. Although Sample 342-U1402B-1H-1W, 75-77 cm, was only half filled $\left(\sim 3.5 \mathrm{~cm}^{3}\right)$, it was volume corrected to $7 \mathrm{~cm}^{3}$.

\section{Results}

Downhole paleomagnetism data for Hole U1402B are presented in Figure F5. Cores from Hole U1402B have steep inclination values $\left(70^{\circ}-90^{\circ}\right)$ measured prior to demagnetization that generally become shallower after AF demagnetization at $20 \mathrm{mT}$. We interpret this behavior as a substantial drilling overprint, primarily a viscous isothermal remanent magnetization (IRM), that is typical for cores from Deep Sea Drilling Project, ODP, and IODP operations.

AF demagnetization results for the eight discrete samples are summarized in Table T3. Stepwise AF demagnetization on the samples reveals a stable component of magnetization that is resolved for treatment levels above $10 \mathrm{mT}$ (Fig. F6A, F6C). Sample 342-U1402B-1H-2W, 79-81 cm, did not record a stable component (Fig. F6B); it was collected from a horizon that probably consists of magnetically soft (very low coercivity) minerals ( 2.3 mbsf; Fig. F5). Our results indicate that viscous overprinting is successfully removed by AF demagnetization up to 10 $\mathrm{mT}$. Thus, NRM following $20 \mathrm{mT}$ demagnetization is a reliable indicator of characteristic remanent magnetization (ChRM). NRM intensities and directions after $20 \mathrm{mT}$ demagnetization are generally consistent between the archive halves and the discrete samples (Fig. F5). Three samples $(8.13,10.80$, and 12.33 mbsf) record inclinations that are inconsistent with the pass-through magnetometer data. These samples were taken from Core 342-U1402B-2H, and the disturbance probably affected the declination results (see below).

For the uppermost $\sim 3 \mathrm{~m}$, inclination and declination show generally stable directions. Except for the horizon at $\sim 2.3 \mathrm{mbsf}$, inclination varies between $\sim 30^{\circ}$ and $\sim 60^{\circ}$. These values are consistent with the 
expected inclination of $\sim 60^{\circ}$ from the geocentric axial dipole (GAD) field at the latitude of Site U1402. In contrast, the 7-14 mbsf depth interval (Core 342U1402B-2H) shows generally steep inclination and highly variable declination. We attribute this variability to core disturbance; the plastic liner for Core $2 \mathrm{H}$ shattered during recovery. See "Lithostratigraphy" for a full discussion of core disturbance.

\section{Magnetostratigraphy}

If we tentatively include the 7-14 mbsf depth interval (Core 342-U1402B-2H), then sediment from Hole U1402B is characterized by normal polarity except for a short interval at 6.15-6.20 mbsf (interval 342-U1402B-1H-5A, 15-20 cm). Site U1402 is a reoccupation of Site 1073, at which Chron C1n (Brunhes normal polarity chron) was identified downhole to 515 mbsf (Shipboard Scientific Party, 1998). We follow this prior work and also ascribe the normal polarity observed in Hole U1402B sediment to Chron C1n. This interpretation is consistent with the biostratigraphic results (see "Biostratigraphy"). The brief polarity reversal observed in both inclination and declination at 6.15-6.20 mbsf may record a short geomagnetic reversal event. A similarly shallow and short reversal event was reported at 14.8-15.7 mbsf at Site 1073 (Shipboard Scientific Party, 1998) and was provisionally identified as either the Laschamp or Blake excursion. Nannofossil biostratigraphy indicates, however, that the base of Hole U1402B cannot be older than $70 \mathrm{ka}$ (see "Biostratigraphy"), so we interpret the reversal at 6.15-6.20 mbsf to be the $\sim 38-40$ ka Laschamp excursion (Plenier et al., 2007). Shore-based radiocarbon dating may provide additional age control to verify this conclusion.

\section{Magnetic susceptibility and anisotropy of magnetic susceptibility}

Bulk susceptibility measured on discrete samples is summarized in Table T4. Downhole variation for whole-round magnetic susceptibility (WRMS) and discrete sample magnetic susceptibility (DSMS) are shown in Figure F5. The WRMS data for Hole U1402B are shown in raw form; they have not been trimmed at section ends or filtered for obvious outliers, so noise in the data probably reflects edge effects or spurious measurements. We multiplied the WRMS data, which are in instrument units, by a factor of $0.577 \times 10^{-5}$ to convert to approximate SI volume susceptibilities (see "Paleomagnetism" in the "Methods" chapter [Norris et al., 2014b]). WRMS and DSMS data agree very well after this conversion, and we attribute small absolute differences to the fact that the conversion factor applied to the WRMS data is not constant downhole because of changes in core diameter and density; only discrete samples provide calibrated susceptibility values in SI units. Magnetic susceptibility of the discrete samples is invariant with depth and is between 250-450 $\mu$ SI.

AMS results for the discrete samples are summarized in Table T4. The eigenvalues associated with the maximum $\left(\tau_{1}\right)$, intermediate $\left(\tau_{2}\right)$, and minimum $\left(\tau_{3}\right)$ susceptibilities indicate that the magnetic fabric becomes increasingly oblate with depth (Fig. F7). Moreover, both the inclination of $\mathrm{V}_{3}$ (minimum principal eigenvector) and the degree of anisotropy $\left(P ; \tau_{1} / \tau_{3}\right)$ increase with depth. These changes in magnetic fabric are common in sediment (Schwehr et al., 2006) and can be readily attributed to compaction of clays with burial. The very low $\mathrm{V}_{3}$ inclination at 8.13 mbsf may be due to core disturbance in this interval.

\section{Geochemistry}

The geochemistry program carried out routine shipboard analyses for Site U1402, including

- Analysis of interstitial gas compounds on headspace samples;

- Measurement of minor and trace element concentrations in interstitial water squeezed from a whole-round sample from Hole U1402B; and

- Inorganic carbon, total carbon, and total nitrogen determinations of solid sediment samples from Hole U1402A.

\section{Sediment gas sampling and analysis}

One headspace sample was taken from Hole U1402B as part of the routine environmental protection and safety monitoring program (Table T5). The concentration of methane $\left(\mathrm{CH}_{4}\right)$ in Section 342-U1402B-1H4 was $4.5 \mu \mathrm{L} / \mathrm{L}$ (ppmv). Other hydrocarbon gases were not detected.

\section{Interstitial water chemistry}

One interstitial water sample was collected from Hole U1402B. The interstitial water was squeezed from a $10 \mathrm{~cm}$ whole-round sample from the bottom of Section 342-U1402B-1H-3, which was cut on the catwalk after Core $1 \mathrm{H}$ was sectioned. The top depth of this whole-round section is 3 mbsf. Interstitial water components are tabulated in Table T6.

\section{Depositional environment control on interstitial water chemistry}

Site U1402 is in a very different depositional environment compared to the other Expedition 342 sites. As a result, the interstitial fluid geochemistry data, 
although limited to only one sample, look very different than those from samples described in subsequent Expedition 342 site chapters. A notable example is in the high alkalinity and ammonium $\left(\mathrm{NH}_{4}^{+}\right)$ concentrations and low sulfate concentrations.

Alkalinity in the interstitial water sample in Hole $\mathrm{U} 1402 \mathrm{~B}$ is $13.77 \mathrm{mM}$, considerably higher than the alkalinity of average seawater $(2.33 \mathrm{mM}$ based on the International Association of Physical Sciences of the Ocean [IAPSO]). Replicate alkalinity titrations of IAPSO standard seawater during operations at Site U1402 are consistent with the accepted alkalinity value (within 1\%) for this standard. The $\mathrm{pH}$ of the interstitial water sample is 7.7 , which is within the $\mathrm{pH}$ range of average seawater (7.7-8.1). The concentration of ammonium in Core $342-\mathrm{U} 1402 \mathrm{~B}-1 \mathrm{H}$ is $1590 \mu \mathrm{M}$. Sulfate $\left(\mathrm{SO}_{4}{ }^{2-}\right)$ concentration is $9.1 \mathrm{mM}$.

In the absence of additional interstitial water measurements, it is difficult to place these data into a geochemical framework. However, as compared to other interstitial water data collected during Expedition 342, this sample has higher alkalinity and ammonium concentrations and lower concentrations of sulfate, the hallmark signatures of organic matter consumption. Given the much shallower depth of Site U1402 relative to the other Expedition 342 sites, it is likely that the interstitial fluids at Site U1402 have been influenced by relatively high organic carbon contents (see "Sediment geochemistry").

High alkalinity and ammonium are most likely produced through the liberation of $\mathrm{CO}_{2}$ and nitrate, respectively, from decaying organic matter. Dissolved inorganic carbon (DIC) concentrations increase as carbonic acid forms and dissociates predominantly into bicarbonate, thus increasing alkalinity. As oxygen and less energetically favorable electron acceptors are depleted, the interstitial fluids develop ammonia at the expense of nitrate and concentrations of sulfate diminish. It is also possible that mobilization of $\mathrm{Ba}$ is responsible for low sulfate, though in the absence of Ba data from Hole U1402B, it is not possible to further examine this hypothesis.

\section{Sediment geochemistry}

Concentrations of total carbon, inorganic carbon, total organic carbon (TOC), and total nitrogen were measured from eight sediment samples $\left(\sim 5 \mathrm{~cm}^{3}\right.$ plugs) taken from working halves of Cores 342U1402B-1H and 2H (Fig. F8; Table T7). Inorganic carbon concentrations range from 0.2 to $2 \mathrm{wt} \%$, which are equivalent to $1.6-17 \mathrm{wt} \%$ calcium carbonate assuming all of the inorganic carbon is present as calcite and/or aragonite. TOC concentrations are $\sim 2$ $\mathrm{wt} \%$, which is typical of mid-slope depositional envi- ronments. Total nitrogen concentrations range from 0.1 to $0.2 \mathrm{wt} \%$.

\section{Physical properties}

We made physical properties measurements on whole-round sections, section halves, and discrete samples from section halves from Cores 342U1402B-1H and 2H. Gamma ray attenuation (GRA) bulk density, magnetic susceptibility, $P$-wave velocity, and natural gamma radiation (NGR) measurements were made on all whole-round sections using the Whole-Round Multisensor Logger (WRMSL) and Natural Gamma Ray Logger (NGRL). Section 342U1402B-2H-6 was deformed during drilling and could not be measured in the NGRL. The Section Half Multisensor Logger (SHMSL) was used to measure spectral reflectance and magnetic susceptibility on all archive section halves except for Sections 342U1402B-1H-3 and 1H-4 because these sections were kept intact (unsplit) for future analyses. For moisture and density (MAD) analyses, two discrete samples were collected in each section half except Sections $1 \mathrm{H}-3$ and $1 \mathrm{H}-4$. Compressional wave velocity using the $P$-wave caliper (PWC) on section halves was measured at a frequency of two in Sections $1 \mathrm{H}-1$ and $1 \mathrm{H}-2$.

\section{Density and porosity}

Two methods were used to evaluate bulk density at Site U1402. The GRA method provided a bulk density estimate from whole-round sections. The MAD method on discrete samples provided a second, independent measure of bulk density, as well as measurements of dry density, grain density, water content, and porosity.

Changes in MAD and GRA bulk density are well correlated through the sections (Fig. F9). MAD bulk density mean is $1.7 \mathrm{~g} / \mathrm{cm}^{3}$. The GRA bulk density varies from $<1.5$ to $1.88 \mathrm{~g} / \mathrm{cm}^{3}$ and averages 1.64 $\mathrm{g} / \mathrm{cm}^{3}$. Porosity and water content profiles are parallel to one another and relatively constant through the hole (porosity varies between 58 and $66 \mathrm{vol} \%$ and water content between 33 and $41 \mathrm{wt} \%)$. Grain density varies between 2.74 and $2.85 \mathrm{~g} / \mathrm{cm}^{3}$. Small variations can be noted: between 0 and $3 \mathrm{mbsf}$, grain density increases from 2.78 to $2.85 \mathrm{~g} / \mathrm{cm}^{3}$, and between 6 and 14 mbsf, two minima are reached $(2.74$ $\mathrm{g} / \mathrm{cm}^{3}$ at 9.13 and $\left.11.96 \mathrm{mbsf}\right)$.

\section{Magnetic susceptibility}

Magnetic susceptibility was measured using the WRMSL and SHMSL; however, only WRMSL data are reported in Figure F9. The lower resolution measure- 
ments of the WRMSL are sufficient to compare to other physical property parameters. Between 0 and 1 mbsf, magnetic susceptibility values are highly variable, reaching 150 instrument units (IU). In general, however, magnetic susceptibility decreases downhole in the uppermost 6 mbsf from 100 to $50 \mathrm{IU}$. Between 7.5 and 13 mbsf, magnetic susceptibility gradually increases downhole from 20 to $50 \mathrm{IU}$ and is, in general, less variable.

\section{P-wave velocity}

$P$-wave velocity measurements using the $P$-wave logger (PWL) were performed on whole-round sections from Core 342-U1402B-1H. Discrete compressional wave velocity measurements were conducted using the PWC contact probe system on the working halves of Sections 342-U1402B-1H-1 and 1H-2. Results of both methods approximately correlate (Fig. F10). Between 0 and 0.75 mbsf, $P$-wave velocity values decrease from $\sim 1600$ to $1500 \mathrm{~m} / \mathrm{s}$. Below, $P$-wave data remain relatively constant and average $1515 \mathrm{~m} / \mathrm{s}$. Section-half data are, in general, of better quality than those from whole-round sections.

\section{Natural gamma radiation}

NGR measured on whole-round sections ranges from 40 to $60 \mathrm{cps}$ and shows little downhole variability (Fig. F10). Sections 342-U1402B-2H-2 and 2H-6 were deformed during drilling and were not measured.

\section{Color reflectance}

Spectral reflectance was measured on archive section halves from Hole U1402B using the SHMSL, except for Sections 342-U1402B-1H-3 and 1H-4, which were not split (Fig. F10). $\mathrm{L}^{*}$ mostly ranges between 20 and 40 and is highly variable between 7.5 and 9.5 mbsf. $\mathrm{a}^{*}$ and $\mathrm{b}^{*}$ show a local peak at $\sim 1$ mbsf. Below 6 mbsf, $\mathrm{a}^{*}$ stays constant, whereas $\mathrm{b}^{*}$ increases between 9 and 12 mbsf.

\section{MDHDS deployment}

The MDHDS is part of a three-component system (Figs. F11, F12) designed to deliver a downhole tool, decouple the tool from the drill string, and recover the tool. The uppermost component is the Multifunction Telemetry Module (MFTM), which allows real-time communication with the ERS and other tools. The ERS delivers and retrieves the MDHDS and the attached downhole tool to the BHA and passes data from a communications tether to the MFTM. The MDHDS, once seated in the BHA, is the platform from which the penetrometer (or some tool to be designed in the future) is deployed (Fig. F12).

\section{Components}

Multifunction Telemetry Module

The MFTM (Fig. F11) is a downhole sonde that allows real-time communication with downhole tools through the Schlumberger armored seven-conductor cable. The MFTM was developed by the Lamont-Doherty Earth Observatory Borehole Research Group and is used both to activate latching of the ERS and to capture data streams from probes attached to the inner core barrel of the MDHDS assembly through a communications tether.

The telemetry system has four components (Fig. F13):

1. The telemetry surface control panel (TSCP);

2. A standard Schlumberger Vector 7-46P sevenconductor armored cable for use in logging operations;

3. A Schlumberger logging equipment cablehead (LEH-QT) that makes the physical and electrical connections from the wireline logging cable to the downhole tool string; and

4. The MFTM, which captures the data stream from the probe and broadcasts it to the surface panel.

The MFTM is designed to work with multiple tool platforms; a series of switches mounted in the communication board allows the user to make adjustments depending on the platform used (Fig. F14). In this particular application, the T2P communicates through a $2 \mathrm{~mm}$ coaxial cable to the ERS. Communication is passed through the ERS to the MFTM through a standard Schlumberger 31-pin connector. This allows real-time monitoring of the formation pressures and temperatures penetrated by the probe. These data can be viewed in real time through simple plots. Data are simultaneously acquired by the TSCP data acquisition software and stored while also being transferred to a second data analysis system for more complicated real-time data manipulation.

\section{Electronic RS}

The ERS (Fig. F11 and violet shading in Fig. F12) was developed by Stress Engineering Services for use with the SCIMPI CORK system and the MDHDS. The ERS deploys and retrieves the MDHDS (or any downhole tool) within the drill pipe on the electric wireline.

The ERS is an adaptation of the standard 3 inch RS running tool designed to run on the Schlumberger logging line. Its purpose is to enable running a downhole tool (with an up-looking RS overshot) on the logging line through the drill string for downhole emplacement. A 24 VDC motor in the ERS is commanded from the surface to rotate until the RS pulling neck on the downhole instrument, probe, or 
tool string is released. This capability is to be used in place of a jarring action to shear off an RS connection or using Kinley cutters. The ERS can also capture a tool with an appropriate up-looking pulling neck. To engage an RS pulling neck profile on deck (or downhole), the ERS has a snap-lock feature for which motorized action is required to unlock and return the tool to a locked position.

The ERS is composed of the electronics section, wired through a sinker bar, to a motor section that contains the latching mechanism at the bottom of the ERS (bottom of Fig. F13 and Fig. F15). The ERS electronics housing is unable to pass through the MDHDS landing shoulder. Therefore, an elongated sinker bar allows the ERS to reach as far as $4.92 \mathrm{~m}$ into the MDHDS outer barrel subassembly to retrieve the MDHDS after it has been deployed (Fig. F16). The ERS is latched at the surface and lowered into the borehole. An electric motor within the ERS is commanded from the surface to rotate until the RS pulling neck on the downhole instrument is released (Fig. F17). This motor can both unlock the ERS from the downhole tool and return the ERS to a locked position so that it can be used to retrieve the downhole tool. A prototype of the ERS was used during IODP Expedition 327 to successfully deploy the Hole U1301B CORK system (Expedition 327 Scientists, 2011).

\section{Motion Decoupled Hydraulic Delivery System}

The MDHDS is composed of an inner barrel subassembly (IBS) (Fig. F18 and green in Fig. F12) and an outer barrel subassembly (OBS) (Fig. F19 and brown in Fig. F12). The penetrometer is attached to the IBS. On the rig floor, before the MDHDS is deployed, the IBS is latched to the OBS (Fig. F20). The latching system (MDHDS latch) is near the bottom of the MDHDS (Fig. F19). When using a narrow-diameter penetrometer like the T2P, the bottom of the MDHDS can be outfitted with a flapper guide tube. This tube protects the penetrometer as it passes through the flapper at the drill bit and acts as a guide to ensure vertical deployment (surrounding T2P, bottom of Fig. F12). For larger diameter penetrometers like the Sediment Temperature-Pressure (SET-P) tool, the flapper guide tube is not used.

The MDHDS latch is cocked with an external lever (Fig. F21). This compresses a 316 stainless steel spring within the MDHDS latch and shifts an internal sleeve to lock the latch piston in place. The latch spring rate is $88 \mathrm{lb} / \mathrm{inch}$. When the spring is locked in the latched position, it is compressed 2.5 inches.

The internal sleeve is then fixed in place with shear pins. The shear screws are off-the-shelf $1 / 4$ inch brass set screws. These screws typically shear at 1330 pound-force $\left(\mathrm{lb}_{\mathrm{f}}\right) \pm 10 \%$. With two shear screws installed, the total force to shear the screws is $~ 2660$ $\mathrm{lb}_{\mathrm{f}}$. With the IBS latched in place, the center of the shear screw head is effectively blanked off. Thus, a piston area is created by the O-ring seals on the outside of the shear screw head sealing inside the shear screw housing. This area is equal to $7.220 \mathrm{in}^{2}$. Therefore, the drill string pressure required to shear the screws and shift the inner latch subassembly is 2660 $\mathrm{lb}_{\mathrm{f}} / 7.220 \mathrm{in}^{2}=368 \mathrm{psi}$.

The latched MDHDS is conveyed by the ERS on the wireline to sit on the landing shoulder of the standard BHA. The MDHDS latch is activated by raising the drill string pressure (Fig. F22A) to shear the two shear screws. When the screws shear, the drill string pressure forces the piston further down until the spring reaches its solid height of 2.34 inches (Fig. F22B). Thus, the spring force is 2.91 inches $\times 88.0$ $\mathrm{lb}_{\mathrm{f}} /$ inch $=256 \mathrm{lb}_{\mathrm{f}}$ in its fully compressed position.

The latch piston pressure area is $1.997 \mathrm{in}^{2}$. Thus, the drill string pressure necessary to balance the spring force is $256 \mathrm{lb}_{\mathrm{f}} / 1.997 \mathrm{in}^{2}=128$ psi. This is well below the pressure required to shear the shear screws (368 psi). When the drill string pressure is released, $256 \mathrm{lb}_{\mathrm{f}}$ of spring force is released. However, the O-ring static friction must be overcome before the piston can move. The latch piston O-ring static friction was measured and found to be $\sim 200 \mathrm{lb}_{\mathrm{f}}$. This means that there is an "overforce" of $\sim 56 \mathrm{lb}_{\mathrm{f}}$ to start the piston moving once the drill string pressure is released. Given the latch piston area of $1.997 \mathrm{in}^{2}$ and the overforce of $56 \mathrm{lb}_{\mathrm{f}}$, the pressure within the drill string must be $<56 \mathrm{lb}_{\mathrm{f}} / 1.997 \mathrm{in}^{2}=28$ psi in order for the latch spring to expand. The rig floor is $\sim 11.5 \mathrm{~m}$ above sea level, and the standpipe drain point in the derrick is $10 \mathrm{~m}$ above the rig floor. Thus, the hydrostatic head inside the undrained drill string is (11.5 $\mathrm{m}+10 \mathrm{~m}) \times 1.46 \mathrm{lb}_{\mathrm{f}} / \mathrm{in}^{2} / \mathrm{m}=31.4 \mathrm{lb}_{\mathrm{f}} / \mathrm{in}^{2}$. Therefore, the standpipe pressure must be bled down to $-3.4 \mathrm{psi}$ for the spring to begin moving the piston upward (-3.4 $\mathrm{psi}+31.4 \mathrm{psi}=28 \mathrm{psi}$ ) into the unlatched position. This means the water level needs to be dropped $\sim 2.2 \mathrm{~m}$ below the standpipe drain point. Once the piston begins to move, the dynamic friction is much less and the piston will move rapidly upward until it shoulders.

Relieving the drill string pressure allows the spring to expand (Fig. F22C), which allows the shear screw housing and dog housing to move downward, unlocking the latch piston, which then remains held in place by the drill string pressure. The IBS is then freed from the OBS (Fig. F22D). At this point, the IBS may fall by its own weight. 
The penetrometer is next pumped into the formation by raising the drill string pressure once more to $\sim 6.9 \mathrm{MPa}$ (1000 psi). The driving force on the penetrometer is roughly the drill string pressure multiplied by the inner diameter (ID) of the area of the flapper tube. The flapper tube has a 3 inch ID and the area equals $7.069 \mathrm{in}^{2}$. The seal is leaky, so this is an approximate calculation. The piston area that creates the SET-P driving force is created by the tight fit between the IBS and the MDHDS latch. The procedures call for doubling the drill string pressure as used for the T2P, 13.8 to $17.23 \mathrm{MPa}$ (2000 psi to 2500 psi), to drive the SET-P into the formation.

During this test, we installed a tension device inside the IBS to house a communications tether. The tether allowed real-time communication from the penetrometer to the rig floor. This tension device, consisting of a rigid and elastic cable and a series of pulleys, held the communications tether in tension at all times, taking up slack as the drill string heaved downward and letting it out as it heaved upward (Fig. F23). The tether is connected to the top of the T2P and the bottom of the ERS with TeledyneImpulse IE4M connectors (Fig. F24).

\section{Deployment}

On the rig floor, the MDHDS is assembled, the latch set, and the penetrometer attached. The MDHDS and the penetrometer are then hoisted into position using the MDHDS lifting clamp, attached just below the fishing neck (Fig. F25). The penetrometer and the MDHDS are lowered inside the drill string until the MDHDS rests on the lifting clamp at the top of the drill pipe (Fig. F26). The wireline with the attached MFTM and ERS is lowered to $\sim 1 \mathrm{~m}$ above the fishing neck. If a tether is used, the tether is pulled up from where it rests within the fishing neck, and the IE4M connector at the up end of the tether is mated with the IE4F outlet at the base of the ERS (Fig. F27). The IE4 locking nut is then installed. The wireline is then slowly lowered until the ERS latches onto the fishing neck at the top of the IBS. A communications test is run to ensure data from the T2P is properly transmitted through the Schlumberger wireline to the data acquisition computer. Once communication is confirmed, the entire assembly is lifted $1 \mathrm{~m}$, the MDHDS lifting clamp is removed, and the tool string is lowered into the drill string. If a tether is not used, then the ERS is lowered until it latches to the fishing neck. Wireline tension is monitored during lowering.

Prior to deployment, the BHA should be positioned $1.5 \mathrm{~m}$ above the bottom of the hole (Fig. F28A). The static wireline load is recorded just before the MDHDS is landed in the BHA, and MDHDS is then landed in the BHA. The MFTM actuates the ERS to unlatch the MDHDS, and the ERS is raised $3 \mathrm{~m}$ (Fig. F28B). When the ERS is picked up, the load should be substantially less than the load present just before the MDHDS was rested on the BHA landing shoulder. If the load does not drop off, then the ERS did not successfully unlatch and the process is repeated. In this configuration, wireline tension should drop $\sim 500 \mathrm{lb}_{\mathrm{f}}$ after a successful unlatching. If unlatching is successful, then deployment may begin. With the MDHDS latched and landed in the BHA, all the drill string fluid is forced through the center of the OBS through a contact seal between the MDHDS landing shoulder and the wall of the BHA. Next, the drill string is slowly pressurized to $\sim 6.9 \mathrm{MPa}(1000 \mathrm{psi})$, a pressure in excess of the 368 psi necessary to shear the brass shear screws. The pressure should be held for 3-5 min to fully transmit the pressure to the shear screws. Pressure is then bled off. This allows the MDHDS latch spring to expand, allowing the latch piston to shift into place with the relief groove directly over the dogs. At this point, the penetrometer may pass through the BHA under its own weight, though it may not.

Approximately $5 \mathrm{~min}$ after pressure is bled off, the drill string pressure is raised once again to $\sim 6.9 \mathrm{MPa}$ (1000 psi) and the probe is pumped out (Fig. F28C). The probe is driven a maximum of $2.9 \mathrm{~m}$ into the formation. After $2.9 \mathrm{~m}$, the piston head seal passes through the flapper guide tube, circulation is reestablished, and there is no more driving pressure on the penetrometer. The BHA is then picked up $2 \mathrm{~m}$ (Fig. F28D), allowing for $\pm 3.0 \mathrm{~m}$ of vertical motion. At this point in the deployment, the OBS is fixed relative to the BHA, and the IBS is fixed relative to the bottom of the hole. There are no seals in contact between the inner and outer barrel, thus no seal friction exists that could induce heave motion into the probe. Circulation is terminated. The penetrometer is now deployed, and the tool is left in place to record pressure and temperature dissipation.

The probe is extracted by using the MFTM to actuate the ERS into a closed position, lowering the MFTMERS assembly until latching with the RS fishing neck that is attached to the MDHDS inner barrel (Fig. F28E). In an ideal deployment, in which the ERS was raised $3 \mathrm{~m}$, the BHA was raised $2 \mathrm{~m}$, and the tool was driven $2.9 \mathrm{~m}$ into the formation, the ERS would have to be lowered $5.8 \mathrm{~m}$ to relatch (Fig. F28C). In this situation, the ERS would be lowered inside the OBS a distance of $2.8 \mathrm{~m}$ to reach the RS fishing neck (Fig. F28E). The ERS can reach a maximum of $4.92 \mathrm{~m}$ inside the OBS before the wider diameter electronics housing of the ERS reaches the landing shoulder 
(Fig. F29). After relatching, the wireline is raised, paying close attention to the wireline tension and ensuring that the tension rises to the predeployment value. Once latching is confirmed, the IBS and penetrometer are pulled from the formation into the OBS (Fig. F28F), where they are well protected during the trip out of the hole. If the probe is embedded so firmly into the formation that the wireline cannot pull it from the formation, then the BHA can be raised to dislodge the probe from the bottom. The MDHDS is retrieved by wireline. On deck, it is laid out as a normal core barrel would be. The flapper tube is removed, allowing access to the T2P, which is then detached from the IBS by disconnecting a quick release connection. The MDHDS latch is then reset in preparation for the next deployment. During this time (if necessary), the hole can be washed down several meters in preparation for another deployment.

\section{Deployment results}

\section{Deployment 1}

After a 2 day transit from Bermuda, the JOIDES Resolution arrived at Site U1402 at 1542 h ship time on 6 June 2012 (Table T8). During the first test, we chose to deploy the MDHDS within the drill string before we had spudded the hole but after the drill string had been deployed to near the seafloor. We planned to lower the MDHDS with the T2P attached, without the tether, stopping during the descent at 200 and $400 \mathrm{~m}$ DRF and once again near the mudline. We would then unlatch the MDHDS, record in situ pressure and temperature briefly, and then bring the MDHDS back to the surface. During a brief team discussion prior to deployment, we decided to run the initial deployment with the tether attached. This decision was influenced by the fact that we'd arrived at Site U1402 nearly $12 \mathrm{~h}$ later than expected because of high seas, and we were concerned that we would not have sufficient time to run our entire testing plan. Because we had not spudded the hole, we installed a locking collar on the IBS to limit the distance it could be advanced to $1.5 \mathrm{~m}$. Otherwise, the IBS would fully extend and the ERS would not be able to reach the distance inside the OBS to retrieve it.

The drill string was deployed to $650 \mathrm{~m}$ DRF and we started recording data with the T2P at $0115 \mathrm{~h}$ on 7 June (Table T9). With the T2P installed on the MDHDS, we ran a communications test between the T2P and the ERS/MFTM prior to deploying in the drill string. Despite several attempts, we were unable to receive the T2P data stream. We received some data, but it was badly distorted and indiscernible. The de- ployment proceeded without connecting the tether to the ERS.

We proceeded with the deployment, latching the ERS to the RS fishing neck, removing the MDHDS lifting clamp, and lowering the wireline into the drill string. As the MDHDS and T2P were lowered into the drill string (at $0436 \mathrm{~h}$ ), there was audible chatter in the drill string, as if the drill string was vibrating; acceleration data recorded by the T2P confirmed a bumpy descent (Fig. F30). At 0450 h, while resting the T2P at $\sim 200 \mathrm{~m} \mathrm{DRF}$, the ERS prematurely released the MDHDS, dropping it $\sim 450 \mathrm{~m}$. The pressure gradient as the tool fell was $0.02 \mathrm{MPa} / \mathrm{s}$, which equates to $\sim 2 \mathrm{~m} / \mathrm{s}$. The premature release of the MDHDS is recorded by the decrease in wireline tension at $2887 \mathrm{~s}$ (Fig. F31). From this point in time, the tip and shaft pressure rose linearly until $13,074 \mathrm{~s}$, when pressure once again reached a constant of 5.97 MPa. We interpret that the modest descent rate was caused by the narrow space between the outer diameter of the OBS and the inner diameter of the drill string.

During the next several hours, we attempted to retrieve the MDHDS with the ERS. We did this by repeatedly raising and lowering the ERS. We tried to completely close the latch before we lowered the ERS. We also tried to close the latch while the ERS was lowered and resting on the RS fishing neck. Every time we picked up on the wireline, there was no increase in tension, indicating that we had not picked up the MDHDS.

We next attempted to unlatch the MDHDS with drill string pressure (Fig. F32). We repeatedly raised the drill string pressure to $8-12 \mathrm{MPa}(1160-1749 \mathrm{psi})$ and held it for $\sim 2 \mathrm{~min}$. When the pressure was reduced, the standpipe pressure never dropped to less than $\sim 20$ psi (dashed line in Fig. F32). We later surmised that the standpipe pressure was not reduced enough to allow the spring to expand against the hydrostatic pressure within the drill string and allow the tool to unlatch. We could not actively monitor the penetrometer position during this sequence because the tether was not attached. However, we know that if the MDHDS unlatched, the circulation would be reestablished after the T2P deployed $2.9 \mathrm{~m}$ (Fig. F28C). The circulation was never reestablished; we surmised that the MDHDS had not deployed.

We then retrieved the ERS and went back into the hole with a mechanical RS. The mechanical RS appeared to latch. However, when the wireline was raised, the weight was not maintained. When the mechanical RS was brought back to the rig floor, we discovered that it parted at its midpoint. At this point, we decided to recover the entire drill string in order to retrieve the MDHDS. 
When the MDHDS was retrieved, the T2P was removed and the data downloaded. At 13,658 s, data acquisition terminated (Fig. F30). When the T2P was opened, it was found that the MDM nine-pin (power) connector on the CDAQ board had dislodged. In addition, the fishing neck on the top of the IBS had several deep gouges. We interpreted that the ERS latch had repeatedly struck the RS fishing neck in attempts to recover it. One of these impacts caused the damage to the MDM nine-pin connector, causing the T2P to lose power and terminating data collection (Fig. F30). At this point, we observed that the ERS was in an overlatched position. We also observed that several screws on the latch motor cover were missing and had likely vibrated out. It was decided that in the next deployment the ERS and T2P would be replaced and that connections would be sealed with a temporary bonding agent (Loctite or similar) to reduce the likelihood of losing screws.

\section{Deployment 2}

At $1900 \mathrm{~h}$, Hole U1402A had been washed to $96.4 \mathrm{~m}$ DSF (Table T10). The T2P was attached to the MDHDS, and a communications test between the Schlumberger wireline and the tool string components was successful. At $2115 \mathrm{~h}$, the MDHDS was deployed by wireline into the drill string. The wireline was held and the pumps turned off at $285 \mathrm{~m}$ and at the mudline for pressure calibration ( $\mathrm{B}$ and $\mathrm{C}$ in Fig. F33; Table T11). At $2227 \mathrm{~h}$, the MDHDS reached the BHA and was released by the ERS (A in Fig. F33; Table T11).

There were three attempts to unlatch the MDHDS, and these are recorded by increases in the standpipe pressure (Fig. F34). The first pressurization sequence began at $-958 \mathrm{~s}$, lasted $61 \mathrm{~s}$, and reached a peak pressure of $9.18 \mathrm{MPa}$ (1331 psi). The second attempt began at $-782 \mathrm{~s}$, lasted $22 \mathrm{~s}$, and reached a peak 9.23 $\mathrm{MPa}$ (1339 psi). The third pressurization sequence began at $-598 \mathrm{~s}$, lasted $147 \mathrm{~s}$, reached a peak pressure of $10.49 \mathrm{MPa}$ (1521 psi). After this last pressurization, when the standpipe pressure was reduced, there was an abrupt increase in both tip and shaft pressure in the T2P (approximately -375 s; D in Figs. F24, F33; Table T11). This is interpreted to record the tool penetrating the formation under its own weight after the MDHDS unlatched.

The first two attempts to unlatch the MDHDS failed. We interpret that in these cases, the drill string pressure was not lowered enough to allow the spring within the MDHDS to overcome the seal friction and expand. In the last pressurization, we pressured to our highest value (1521 psi) and held this pressure for the longest amount of time (147 s; Fig. F34). We interpret that in this case, the head in the standpipe decreased enough to allow the spring to expand.

The drill string was pressurized once more to drive the T2P into the formation ( -210 s; Fig. F35). The pump rate was increased to $\sim 60$ strokes per minute (spm) over $\sim 18 \mathrm{~s}(-218$ to $-200 \mathrm{~s})$, and then the pump rate was reduced to $\sim 30 \mathrm{spm}$. Tip pressure changed very little at this time; however, shaft pressure jumped abruptly at approximately $-180 \mathrm{~s}$ (F in Fig. F35; Table T11). Simultaneously, tip temperature increased (E in Figs. F33, F36; Table T11). We interpret that the tip pressure was already high because it had previously entered the formation when it fell by its own weight. However, when the pump rate was increased, the tool was driven further into the formation, and this was recorded by the increase in shaft pressure and the increase in tip temperature caused by frictional heating. Circulation was held at just below $30 \mathrm{spm}$ for $\sim 2$ min until $0 \mathrm{~s}$ (the start of dissipation; F in Figs. F33, F35). When the pumps were shut off, the pressures in both tip and shaft dropped abruptly over $\sim 10 \mathrm{~s}$. This drop in pressure is interpreted to be from the unloading caused by the reduction in pressure within the drill string.

From 0 to $2000 \mathrm{~s}$, the tip and shaft pressure and the tip temperature record smooth declines that are characteristic of dissipation. During this period, the accelerometer records no movement, despite the presence of significance ship heave (Fig. F36).

At $2046 \mathrm{~s}$ ( $34 \mathrm{~min})$, circulation was initiated (Fig. F37). Initially, circulation was increased to $>50 \mathrm{spm}$, with only a small $(0.33 \mathrm{MPa})$ pressure increase in the standpipe. Circulation was terminated and then restarted at $2154 \mathrm{~s}$. It was increased to $37 \mathrm{spm}$, at which point (2170 s) the standpipe pressure began to rise rapidly to $5.6 \mathrm{MPa}(812 \mathrm{psi})$ at $2188 \mathrm{~s}$. As the standpipe reached the peak pressure, the T2P experienced a slightly vertical jarring force, visible in the acceleration jump at 2179 s (H in Figs. F33, F37; Table T11). At this point, communication with the T2P ceased.

We attempted to retrieve the MDHDS and T2P with the ERS. The ERS successfully latched onto the RS fishing neck of the MDHDS. However, when we pulled on the wireline, the tool would not come free, as is recorded by the successive cycles of increasing wireline tension (I in Figs. F33, F38; Table T11). We also raised the BHA until we were sure that the penetrometer was no longer in the formation and then once again tried to pull on the wireline ( $\mathrm{J}$ in Figs. F33, F38; Table T11). However, the MDHDS would not separate from the BHA. The team concluded that the MDHDS was stuck inside the BHA, and the decision was made to trip out of the pipe. Upon recover- 
ing the tool string, it was discovered that the BHA was filled with sediment, and shredded pieces of the communications tether were wedged between the BHA and OBS, binding the tool string within the BHA.

The second deployment terminated at $0357 \mathrm{~h}$ on 8 June. A helicopter was scheduled to drop off shipboard technicians and pick up the MDHDS engineering team at $1000 \mathrm{~h}$. With more than $6 \mathrm{~h}$ until the helicopter was scheduled to arrive, the science party requested that the ship be offset $20 \mathrm{~m}$ and core collected. This ended the MDHDS engineering tests. The MDHDS engineers departed the ship at $1010 \mathrm{~h}$.

\section{Results}

\section{In situ temperature and pressure}

The pressure and temperature dissipation data were extrapolated using an inverse time approach (e.g., Flemings et al., 2008). These data were plotted against inverse time from 3900 to $4500 \mathrm{~s}$. The extrapolated shaft pressure was $7.66 \mathrm{MPa}$, the extrapolated tip pressure was $7.53 \mathrm{MPa}$, and the extrapolated tip temperature was $9.61^{\circ} \mathrm{C}$ (Fig. F39). We interpret that the tip pressure is a more accurate measure of the two pressure measurements because it has undergone greater dissipation than the shaft pressure. The tip sensor is located on the narrow-diameter tip of the tool and thus induces a smaller pressure perturbation that undergoes a more rapid decline than the shaft pressure. The projected in situ pressure (7.53 $\mathrm{MPa}$ ) is shown on a pressure depth diagram. The pressure is very slightly overpressured (Fig. F40). Similar results were predicted by Dugan and Flemings (2000) based on an indirect measurement based on bulk density.

\section{MDHDS performance}

The MFTM, ERS, and MDHDS worked well in this deployment. The tool successfully unlatched after drill string pressurization (Fig. F34). When the drill string was repressurized, the penetrometer was successfully driven into the formation (Fig. F35). After penetration, both the tip and shaft pressure sensors recorded smooth pressure dissipation profiles. The pressure records are characteristic of those recorded by successful T2P deployments (Flemings et al., 2008). The lack of any motion in the accelerometer (Fig. F36), although there was significant ship heave during the dissipation interval, is evidence that the drill string completely decoupled from the penetrometer. Finally, the penetrometer was undamaged when it was recovered, which indicates that it was driven straight downward and that there were no problems with the flapper valve at the base of the BHA.
We have illuminated the conditions under which the MDHDS latch will deploy (Fig. F24). We interpret that for the latch spring within the MDHDS to expand, the standpipe pressure must be significantly reduced. In particular, the static head must be lowered several meters below the $21.5 \mathrm{~m}$ that it is normally held at. We achieved this during the last pressurization during Deployment 2 (Fig. F34), but we never dropped the pressure low enough for the spring to expand during Deployment 1 (Fig. F32). We interpret that it is not necessary to raise the drill string pressure to $>1000$ psi to shear the shear pins. However, it may be necessary to hold this pressure for several minutes. Not surprisingly, there appear to be significant time lags between the measured surface pressures and the downhole pressures necessary for opening the latch. Without real-time telemetry, the only way that it will be possible to interpret a successful unlatching is by the establishment of circulation after the tool is advanced.

In the midst of the deployment, we circulated, as recorded by a pore pressure increase (H in Fig. F33). Afterward, we turned off circulation. The effect on the long-term pore pressure dissipation was minimal. We interpret that the reason for this is that circulation applies an undrained load on the formation that raises the pore pressure everywhere near the penetrometer. Because the increase in pore pressure is applied everywhere, it does not affect the process of dissipation (the spatial gradients in pressure are not changed). When the circulation is stopped, the load is removed and the dissipation continues. This is important because drillers get very uncomfortable when there is no circulation for prolonged periods. These data suggest that periodic circulation during a penetrometer deployment will not significantly affect the measurement.

Although real-time data were acquired through the tethered system, failure of the tether during circulation shows that a tethered real-time telemetry configuration is not ready for regular shipboard use.

\section{Long-term application}

Based on the outcome of this engineering test, the MDHDS, T2P, and MFTM have been certified for deployment onboard the JOIDES Resolution. Real-time telemetry will not be used until a more reliable communication system is developed. Without the need for a hollow barrel to house the tether system, the IBS has been replaced with an inner rod subassembly (Fig. F41). It has a smaller diameter, is solid, and is stronger. The 316 stainless steel spring has also been replaced with a stiffer Iconel X750. The new stiffer spring has a latch spring rate of $106.4 \mathrm{lb}_{f} /$ inch. This generates $110 \mathrm{lb}_{\mathrm{f}}$ of overforce to start the piston 
moving once the drill string pressure is released. As a result, the standpipe pressure will only need to be bled down to $<27$ psi for the spring to begin moving the piston upward. This should simplify the unlatching process. Additionally, the new inner rod subassembly is designed with a long, large diameter at the bottom to create $2.5 \mathrm{~m}$ of stroke for the SET-P; this will not affect the $2.9 \mathrm{~m}$ stroke for the T2P.

Stress Engineering Services is completing final modifications to the ERS to improve its latching operation. Once the modifications are complete, the ERS will also be certified for onboard deployment by the USIO. The ERS will be used to deploy the SCIMPI tool during IODP Expedition 341S in May 2013.

We hope that the advances in tool delivery allowed by the MDHDS will result in rich pore pressure and temperature data sets for future expeditions and will engender the development of new downhole tools that can be deployed by the MDHDS. More information about the MDHDS can be found at www.ig.utexas.edu/research/facilities/downhole/ mdhds.htm.

\section{References}

Bjørklund, K.R., 1976. Radiolaria from the Norwegian Sea, Leg 38 of the Deep Sea Drilling Project. In Talwani, M., Udintsev, G., et al., Init. Repts. DSDP, 38: Washington (U.S. Govt. Printing Office), 1101-1168. doi:10.2973/ dsdp.proc.38.131.1976

Dugan, B., and Flemings, P.B., 2000. Overpressure and fluid flow in the New Jersey continental slope: implications for slope failure and cold seeps. Science, 289(5477):288-291. doi:10.1126/science. 289.5477 .288

Expedition 327 Scientists, 2011. Expedition 327 summary. In Fisher, A.T., Tsuji, T., Petronotis, K., and the Expedition 327 Scientists, Proc. IODP, 327: Tokyo (Integrated Ocean Drilling Program Management International, Inc.). doi:10.2204/iodp.proc.327.101.2011

Flemings, P.B., Long, H., Dugan, B., Germaine, J., John, C.M., Behrmann, J.H., Sawyer, D., and IODP Expedition 308 Scientists, 2008. Pore pressure penetrometers document high overpressure near the seafloor where multiple submarine landslides have occurred on the continental slope, offshore Louisiana, Gulf of Mexico. Earth Planet. Sci. Lett., 269(3-4):309-325. doi:10.1016/ j.eps1.2007.12.005

Flemings, P.B., Polito, P.J., Pettigrew, T., Iturrino, G.J., Meissner, E., Aduddell, R., Brooks, D., Hetmaniak, C., Huey, D., and Germaine, J.T., in press. The Motion Decoupled Delivery System: a new deployment system for downhole tools is tested at Site U1402, New Jersey Margin. Sci. Drill.

Hollis, C.J., 1997. Cretaceous-Paleocene Radiolaria of Eastern Marlborough, New Zealand. Inst. Geol. Nucl. Sci. Monogr., 17.

Kirschvink, J.L., 1980. The least-squares line and plane and the analysis of palaeomagnetic data. Geophys. J. R. Astron. Soc., 62(3):699-718. doi:10.1111/j.1365246X.1980.tb02601.x

Nigrini, C., and Moore, T.C., 1979. A Guide to Modern Radiolaria. Spec. Publ.-Cushman Found. Foraminiferal Res., 16.

Norris, R.D., Wilson, P.A., Blum, P., Fehr, A., Agnini, C., Bornemann, A., Boulila, S., Bown, P.R., Cournede, C., Friedrich, O., Ghosh, A.K., Hollis, C.J., Hull, P.M., Jo, K., Junium, C.K., Kaneko, M., Liebrand, D., Lippert, P.C., Liu, Z., Matsui, H., Moriya, K., Nishi, H., Opdyke, B.N., Penman, D., Romans, B., Scher, H.D., Sexton, P., Takagi, H., Turner, S.K., Whiteside, J.H., Yamaguchi, T., and Yamamoto, Y., 2014a. Expedition 342 summary. In Norris, R.D., Wilson, P.A., Blum, P., and the Expedition 342 Scientists, Proc. IODP, 342: College Station, TX (Integrated Ocean Drilling Program). doi:10.2204/ iodp.proc.342.101.2014

Norris, R.D., Wilson, P.A., Blum, P., Fehr, A., Agnini, C., Bornemann, A., Boulila, S., Bown, P.R., Cournede, C., Friedrich, O., Ghosh, A.K., Hollis, C.J., Hull, P.M., Jo, K., Junium, C.K., Kaneko, M., Liebrand, D., Lippert, P.C., Liu, Z., Matsui, H., Moriya, K., Nishi, H., Opdyke, B.N., Penman, D., Romans, B., Scher, H.D., Sexton, P., Takagi, H., Turner, S.K., Whiteside, J.H., Yamaguchi, T., and Yamamoto, Y., 2014b. Methods. In Norris, R.D., Wilson, P.A., Blum, P., and the Expedition 342 Scientists, Proc. IODP, 342: College Station, TX (Integrated Ocean Drilling Program). doi:10.2204/ iodp.proc.342.102.2014

Plenier, G., Valet, J.-P., Guérin, G., Lefèvre, J.-C., LeGoff, M., and Carter-Stiglitz, B., 2007. Origin and age of the directions recorded during the Laschamp event in the Chaîne des Puys (France). Earth Planet. Sci. Lett., 259(34):414-431. doi:10.1016/j.epsl.2007.04.039

Schwehr, K., Tauxe, L., Driscoll, N., and Lee, H., 2006. Detecting compaction disequilibrium with anisotropy of magnetic susceptibility. Geochem., Geophys., Geosyst., 7(11):Q11002. doi:10.1029/2006GC001378

Shipboard Scientific Party, 1998. Site 1073. In Austin, J.A., Jr., Christie-Blick, N., Malone, M.J., et al., Proc. ODP, Init. Repts., 174A: College Station, TX (Ocean Drilling Program), 153-191. doi:10.2973/

odp.proc.ir.174A.105.1998

Publication: 3 March 2014 MS 342-103 
Figure F1. A. Bathymetric map of New Jersey continental slope (National Geophysical Data Center, www.ngdc.noaa.gov/mgg/bathymetry/hydro.html). ODP Leg 174A Site 1073 is located at $639 \mathrm{~m}$ water depth on a smooth portion of the slope (Shipboard Scientific Party, 1998). B. Two-way traveltime dip seismic Line 1002 showing regional Miocene-Pleistocene stratigraphy. Black lines identify age boundaries. In the smooth zone, Pleistocene sediments completely cover Miocene strata, whereas the Miocene is exposed where canyons are present. Modified from Dugan and Flemings (2000).

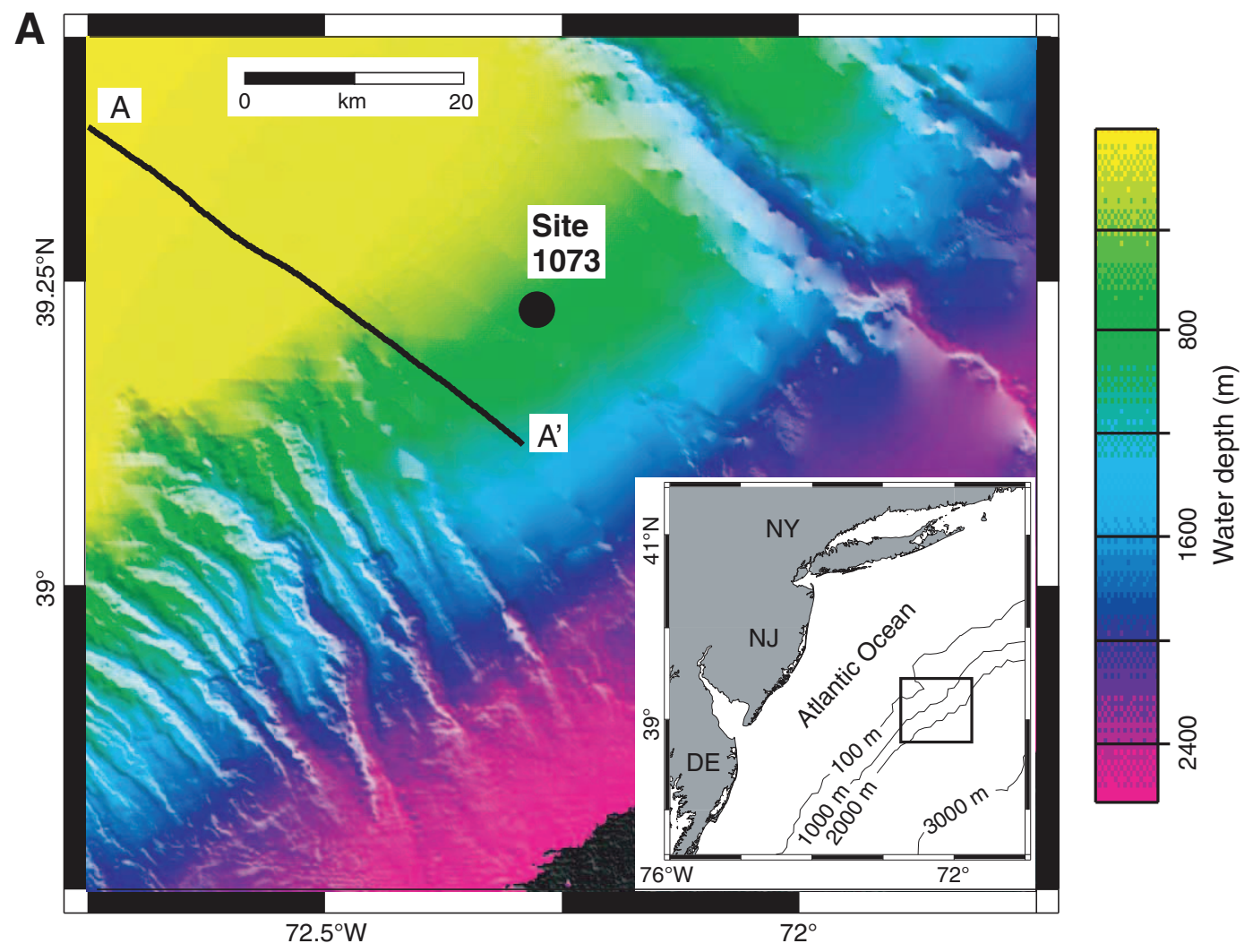

B

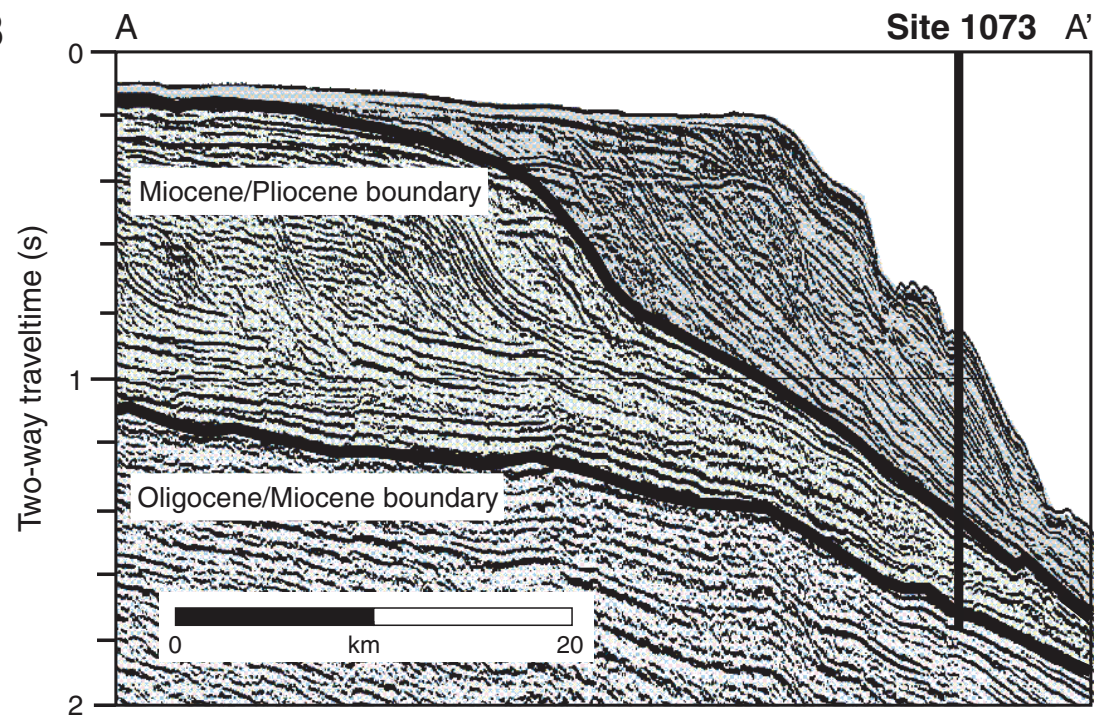


Figure F2. Core data from ODP Site 1073 (Shipboard Scientific Party, 1998). Porosity was determined from shipboard moisture and density measurements. Overpressure $\left(\mathrm{P}^{\star}\right)$ predicted from porosity by Dugan and Flemings (2000). Sedimentation rates and ages are determined from biostratigraphic data. Modified from Dugan and Flemings (2000). Vf. = very fine.

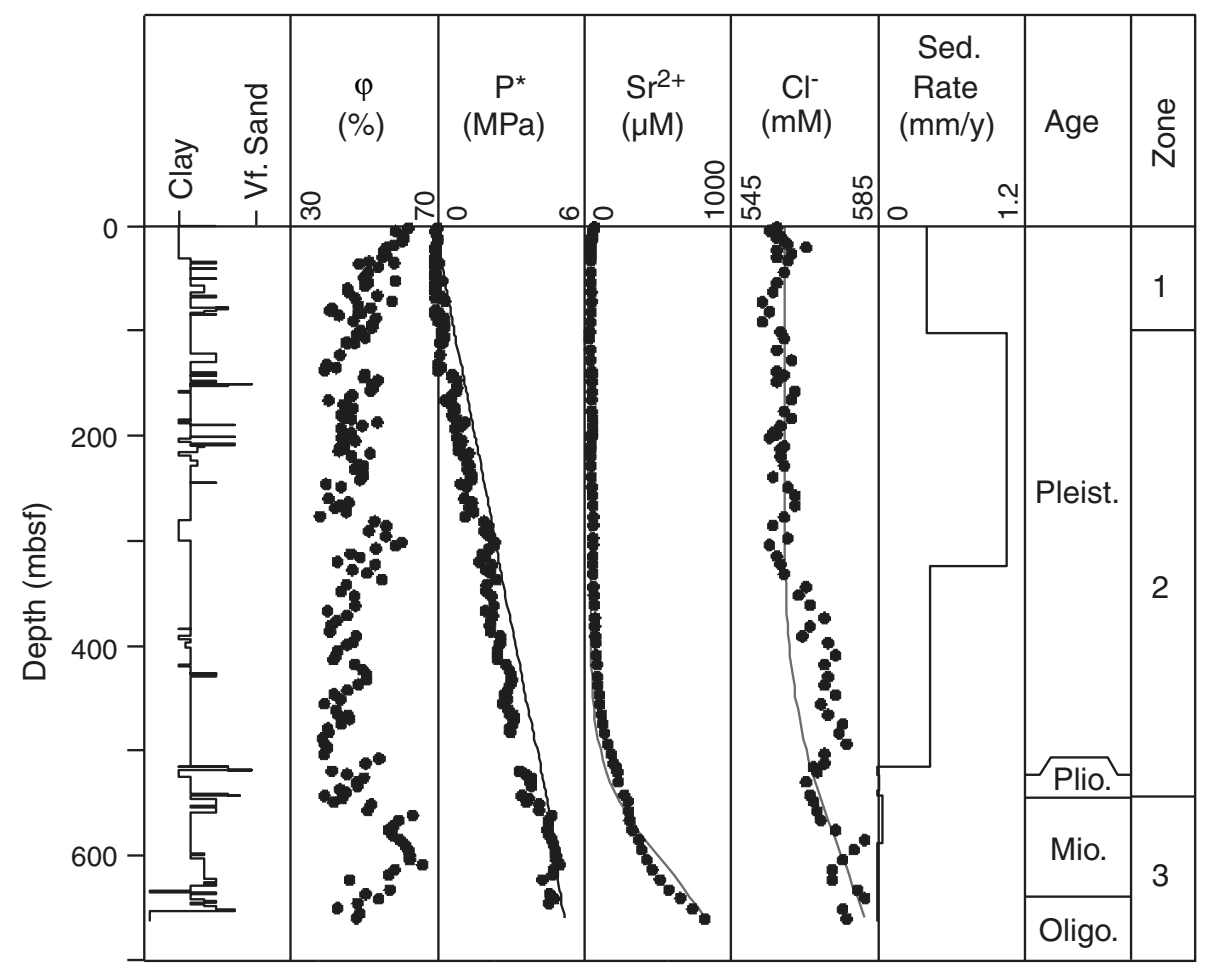


Figure F3. Lithologic summary, Hole U1402B. Gaps in section-half measurements and lithostratigraphy are because the entirety of Sections 342-U1402B-1H-3 and 1H-4 were left unsplit.

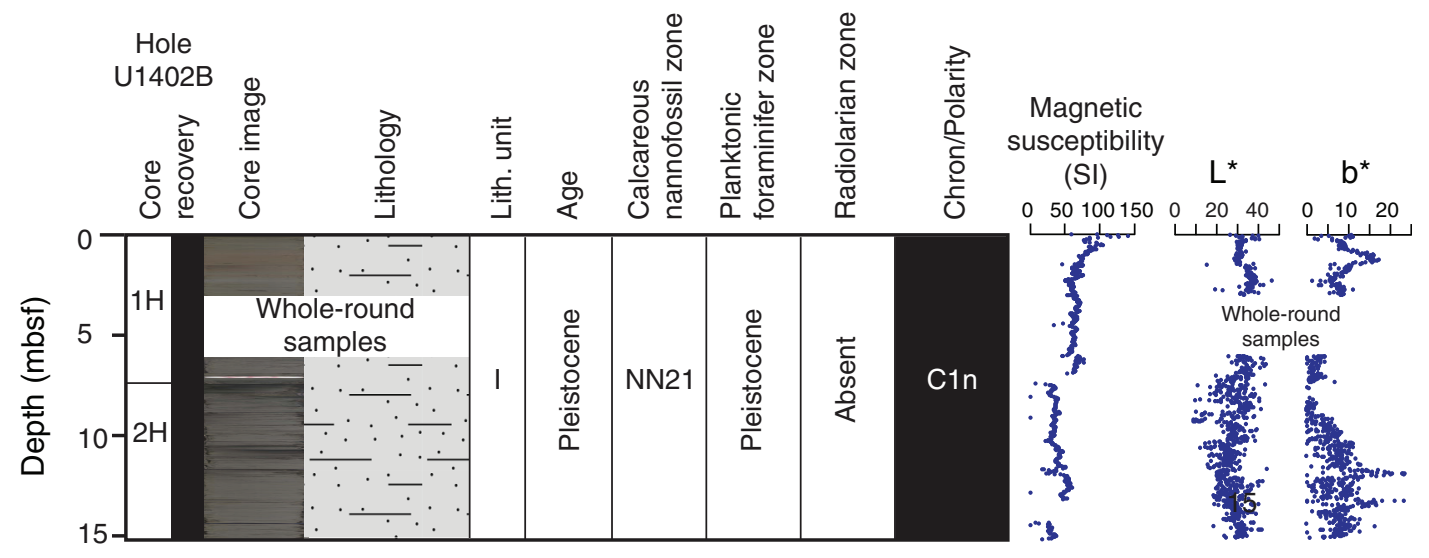


Figure F4. Core images of (A) representative lithology and (B) close-up of monosulfide mottling, Hole U1402B. The appearance of horizontal lines and streaking are the result of core surface scraping, not sediment lamination.

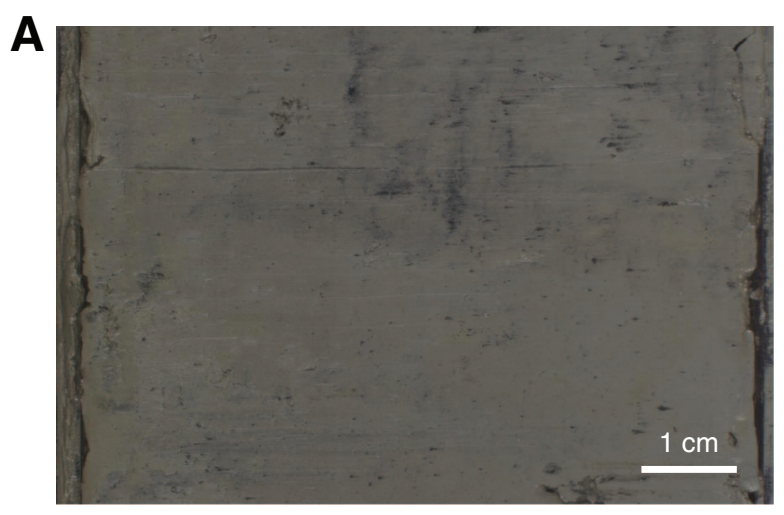

342-U1402B-2H-5, 60-65 cm

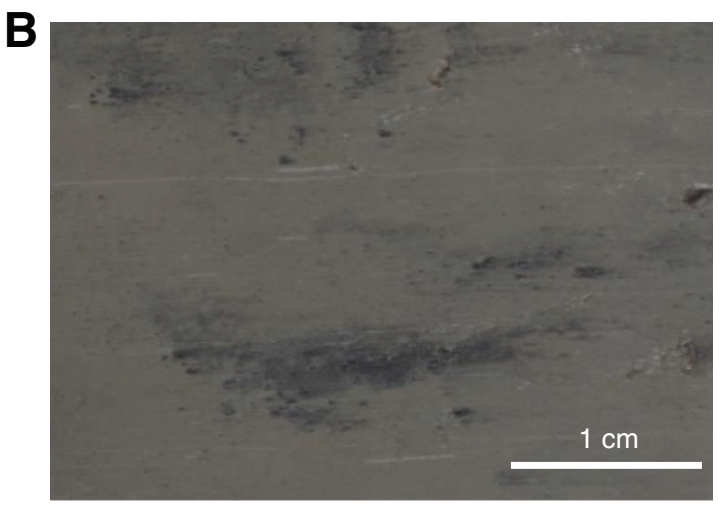

342-U1402B-2H-6, 36.5-38.5 cm 
Figure F5. Plots of downhole variation of magnetic susceptibility and paleomagnetism data, Hole U1402B. Declinations are shown in sample coordinates (not reoriented to geographical coordinates). For discrete sample data, if the samples were analyzed by principal component analysis (PCA; Kirschvink, 1980), then directions are shown according to PCA declination and inclination. Otherwise, directions after $20 \mathrm{mT}$ demagnetization are shown.

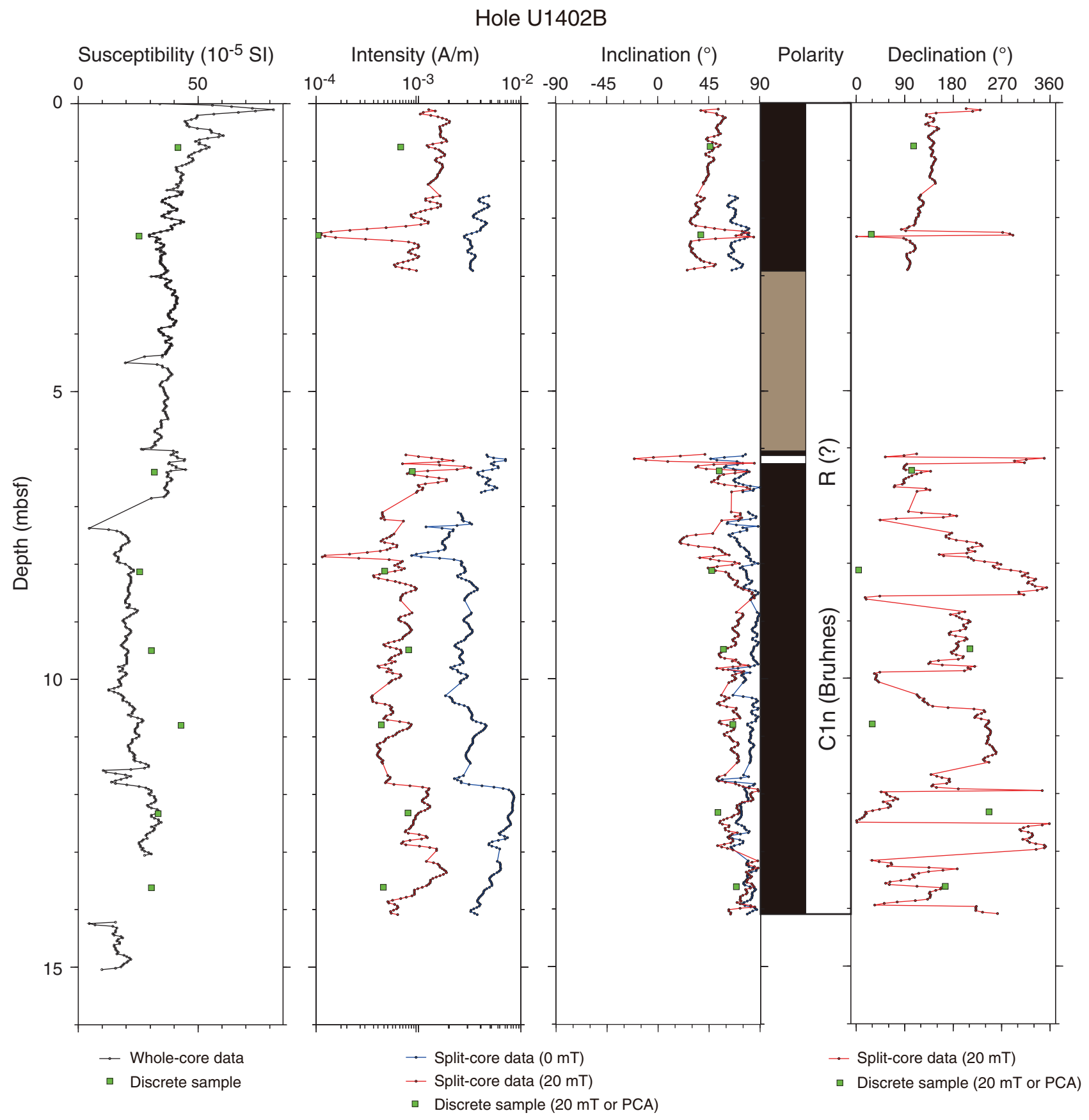


Figure F6. Plots of representative alternating field (AF) demagnetization results for discrete paleomagnetism samples, Site U1402. Upper plots show intensity variation with progressive demagnetization, and lower plots show vector endpoints of paleomagnetic directions on orthogonal vector diagrams (i.e., Zijderveld plots). Vector diagrams indicate that samples in $\mathbf{A}$ and $\mathbf{C}$ record well-resolved characteristic remanent magnetization $(\mathrm{ChRM})$ directions, whereas the sample in $\mathbf{B}$ does not. Solid circles $=$ horizontal projections, open circles $=$ vertical projections, gray circles $=$ data not used to calculate ChRM direction, black dashed line $=$ ChRM direction. Inc $=$ inclination, $\mathrm{Dec}=$ declination, $\mathrm{MAD}=$ maximum angle of deviation .
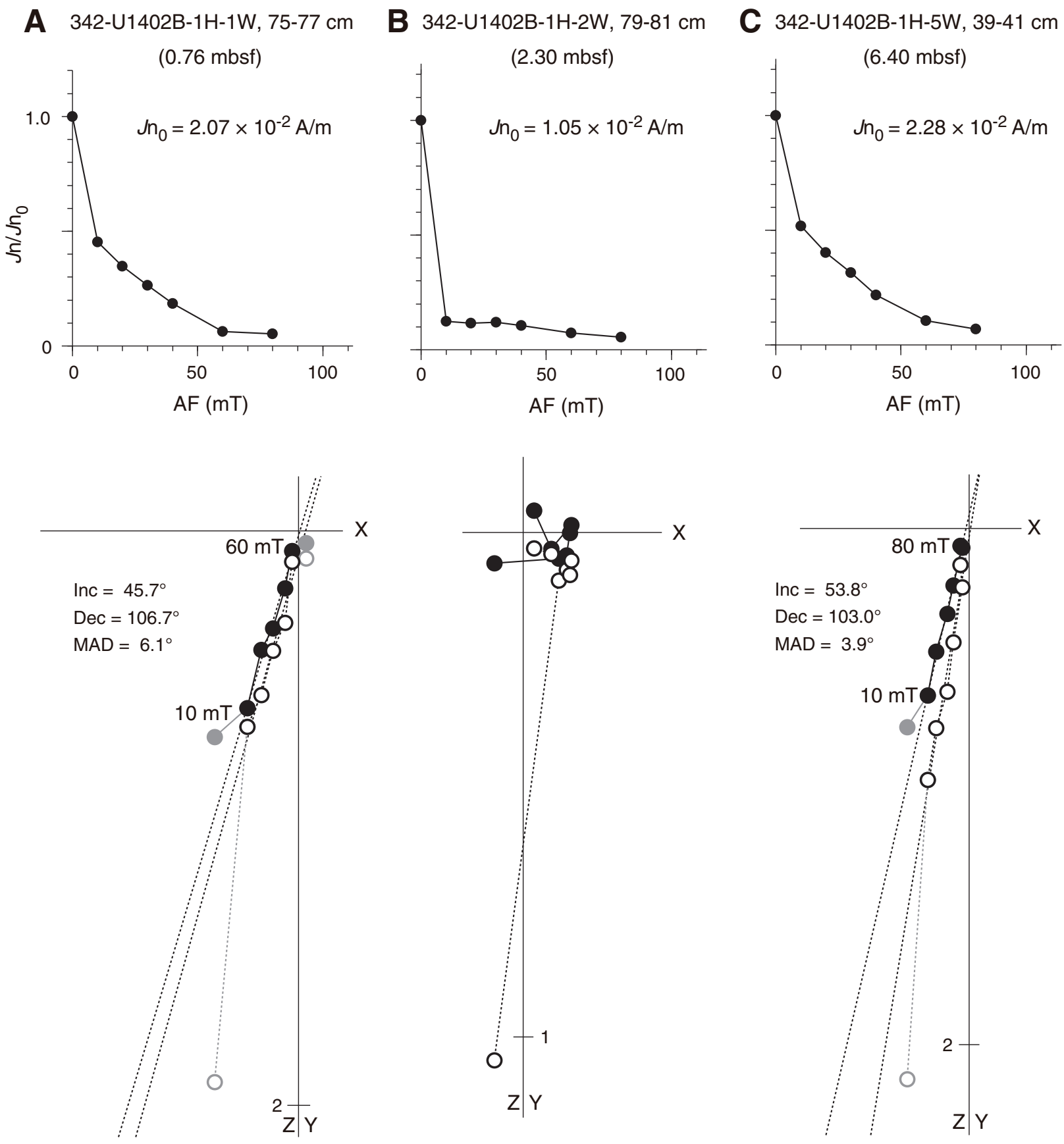
Figure F7. Plots of anisotropy of magnetic susceptibility vs. depth, Hole U1402B. Eigenvalues: $\tau_{1}=$ maximum, $\tau_{2}=$ intermediate, $\tau_{3}=$ minimum. Separation of eigenvalues is related to the shape and degree of magnetic fabric (see "Paleomagnetism" in the "Methods" chapter [Norris et al., 2014b]). For example, if $\tau_{1}$ and $\tau_{2}$ are close or indistinguishable but distinct from $\tau_{3}$, then the bulk fabric is oblate. $\mathrm{V}_{3}=$ minimum eigenvector, $P=$ degree of anisotropy $\left(\tau_{1} / \tau_{3}\right)$.

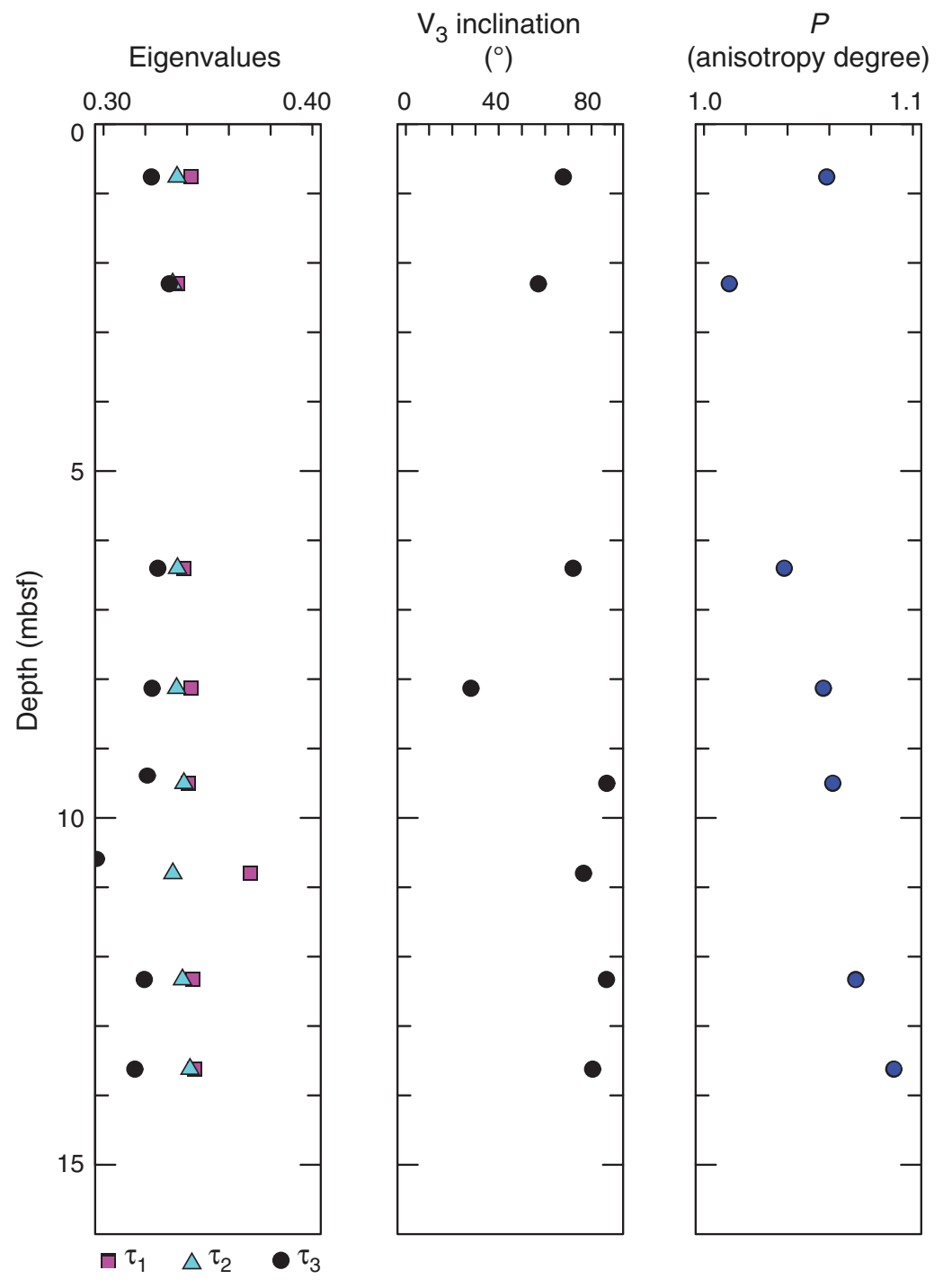


Figure F8. Plots of sediment geochemistry, Hole U1403B. TOC = total organic carbon.
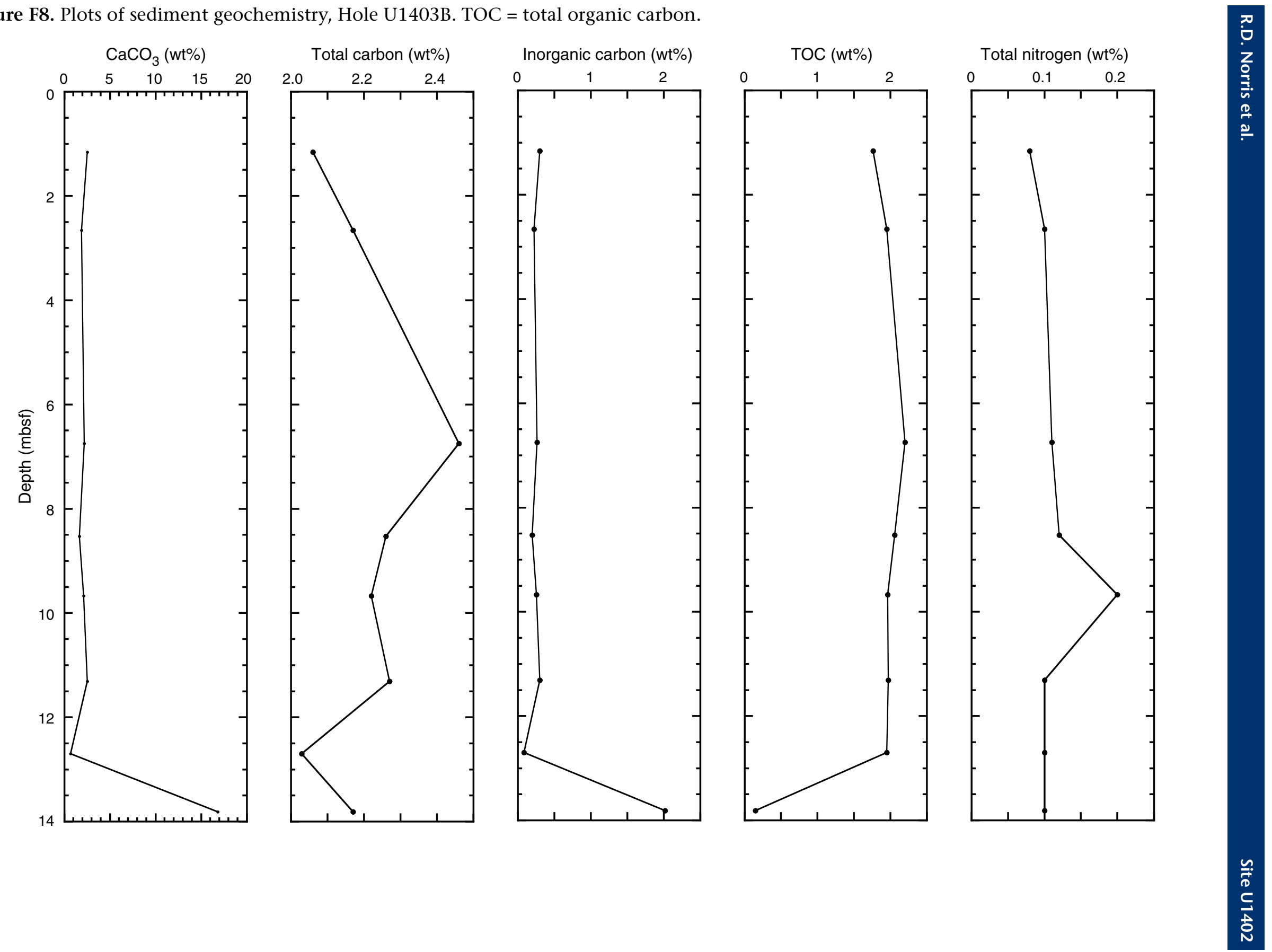
Figure F9. Plots of magnetic susceptibility, bulk density (gray line = gamma ray attenuation bulk density from whole-round sections, black circles = moisture and density bulk density from discrete samples), porosity, water content, and grain density, Hole U1402B.

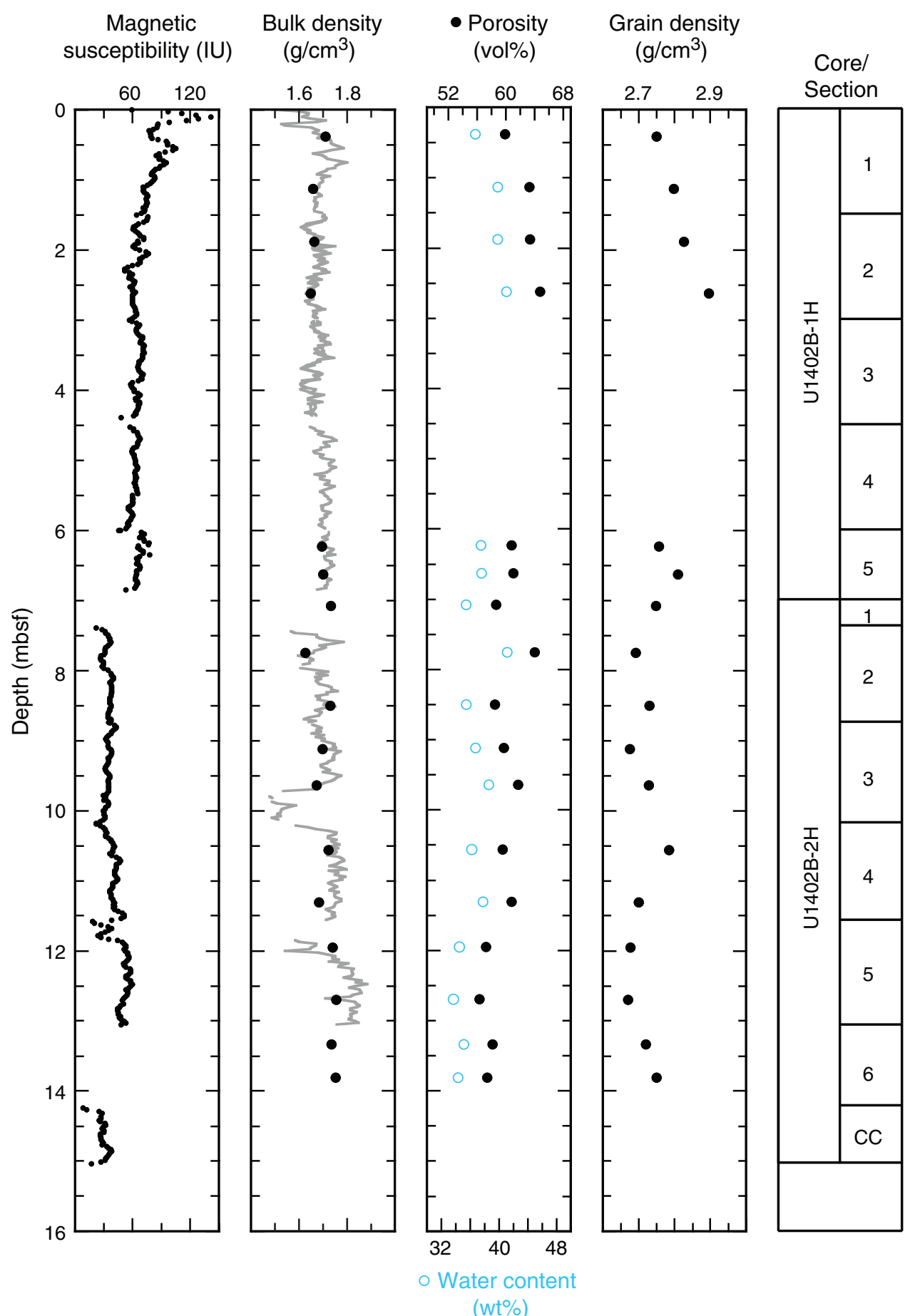


Figure F10. Plots of magnetic susceptibility, $P$-wave velocity (gray line $=P$-wave logger data from whole-round sections, black circles = discrete measurements from working section halves), natural gamma radiation (NGR), and color reflectance $\left(\mathrm{L}^{*}, \mathrm{a}^{*}, \mathrm{~b}^{*}\right)$, Hole U1402B.

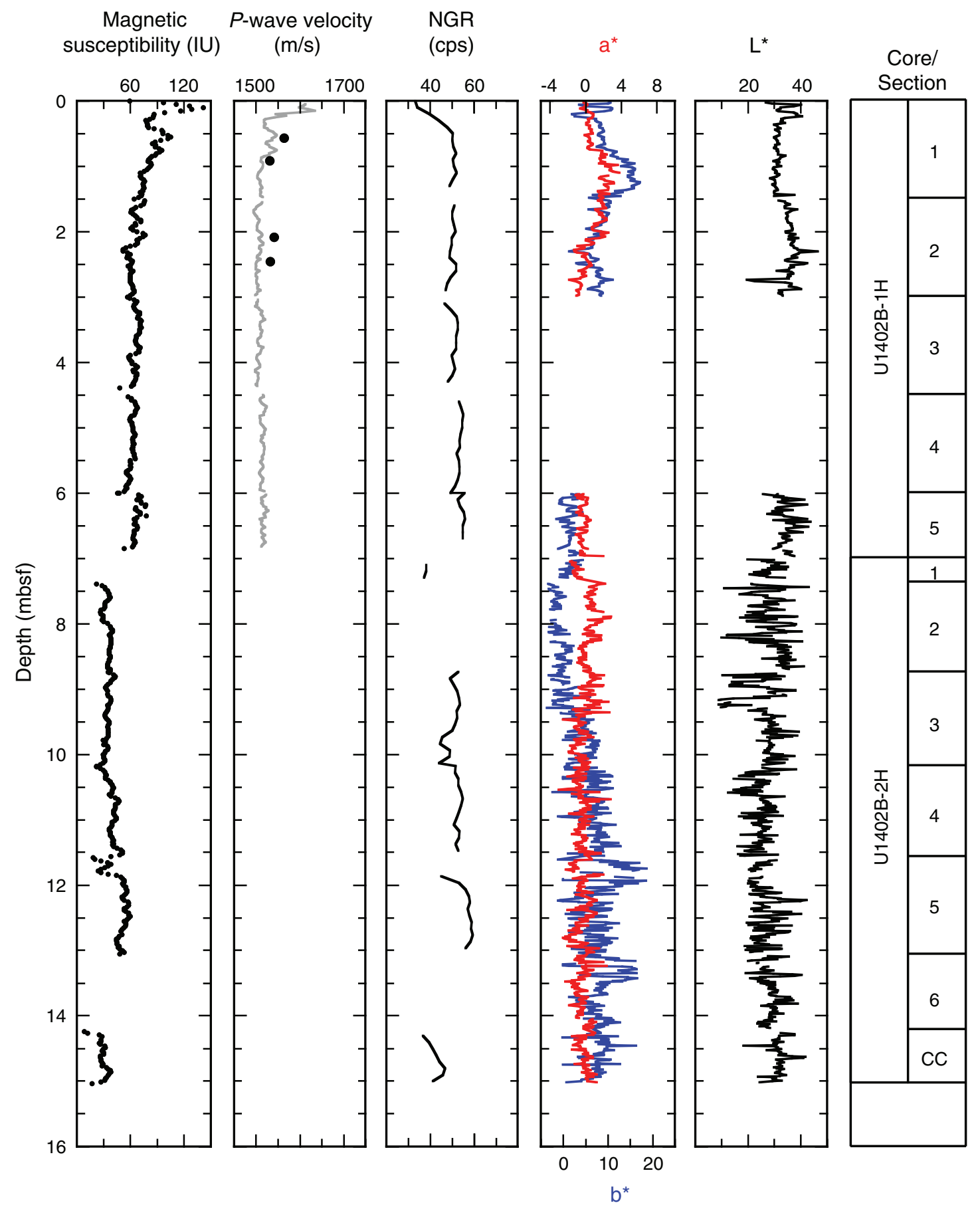


Figure F11. Diagrams and photographs of the three Motion Decoupled Hydraulic Delivery System (MDHDS) components, Expedition 342. The multiFunction Telemetry Module (MFTM) allows real-time communication with the electronic RS (ERS) and other tools. The ERS delivers and retrieves the MDHDS and the attached downhole tool to the bottom-hole assembly (BHA). The MDHDS, once seated in the BHA, is the platform from which the penetrometer (or some tool to be designed in the future) is deployed. Two penetrometers, the temperature-dual-pressure probe (T2P) and the Sediment Temperature-Pressure Tool (SET-P) can be deployed with the MDHDS.

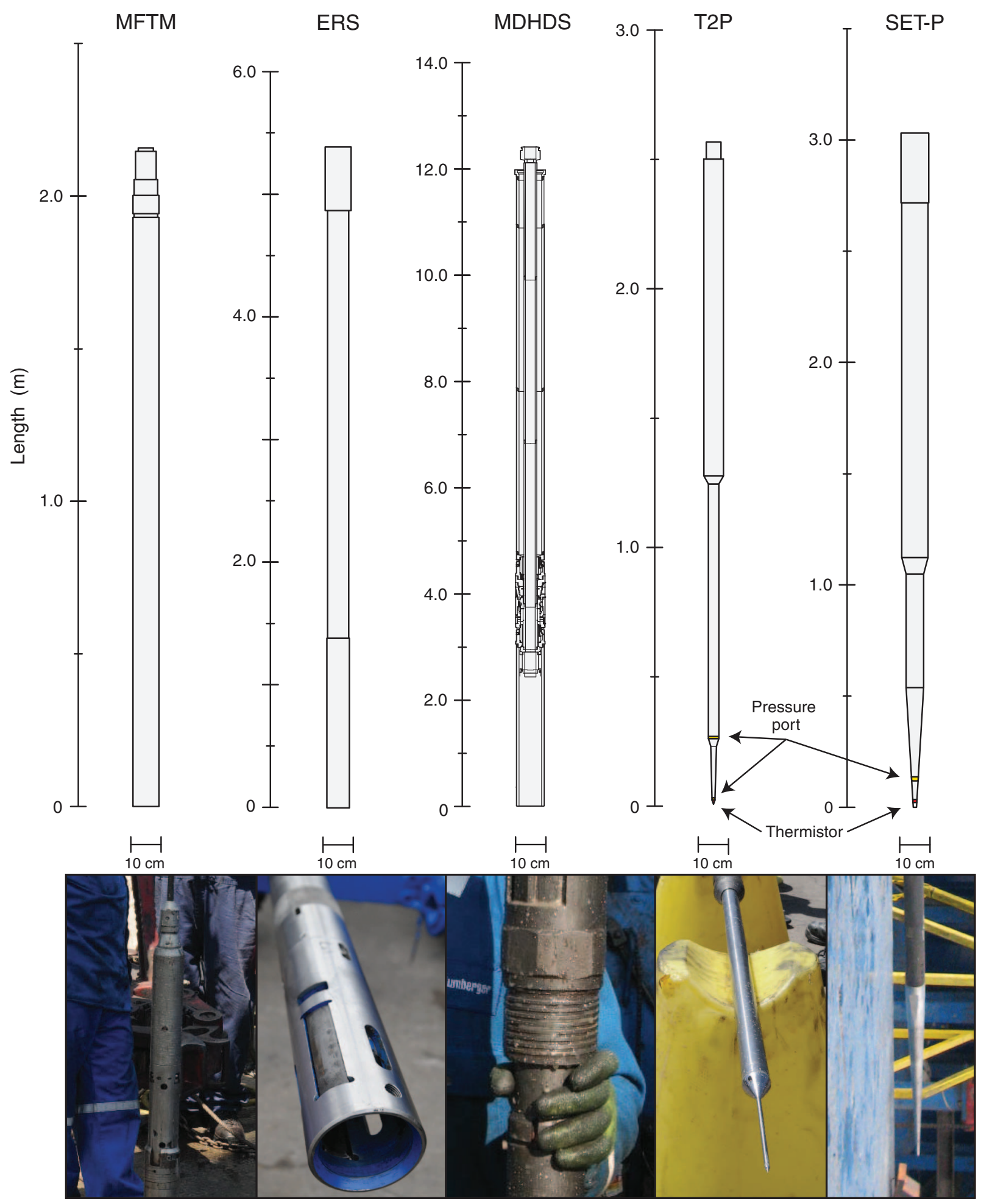


Figure F12. Diagram of the Motion Decoupled Hydraulic Delivery System (MDHDS) assembly, Expedition 342. The multiFunction Telemetry Module (not shown) is attached directly to the Schlumberger electric wireline and is in turn attached to the electronic RS (ERS). The MDHDS is composed of an outer barrel subassembly (brown) and an inner barrel subassembly (green). The top of the inner barrel is capped by the RS fishing neck. The pore pressure penetrometer (red) is shown in this example as the temperature-dual-pressure probe (T2P) but the Sediment Temperature-Pressure Tool or Sediment Temperature Tool can also be used. The entire MDHDS sits on the landing shoulder of the bottom-hole assembly.

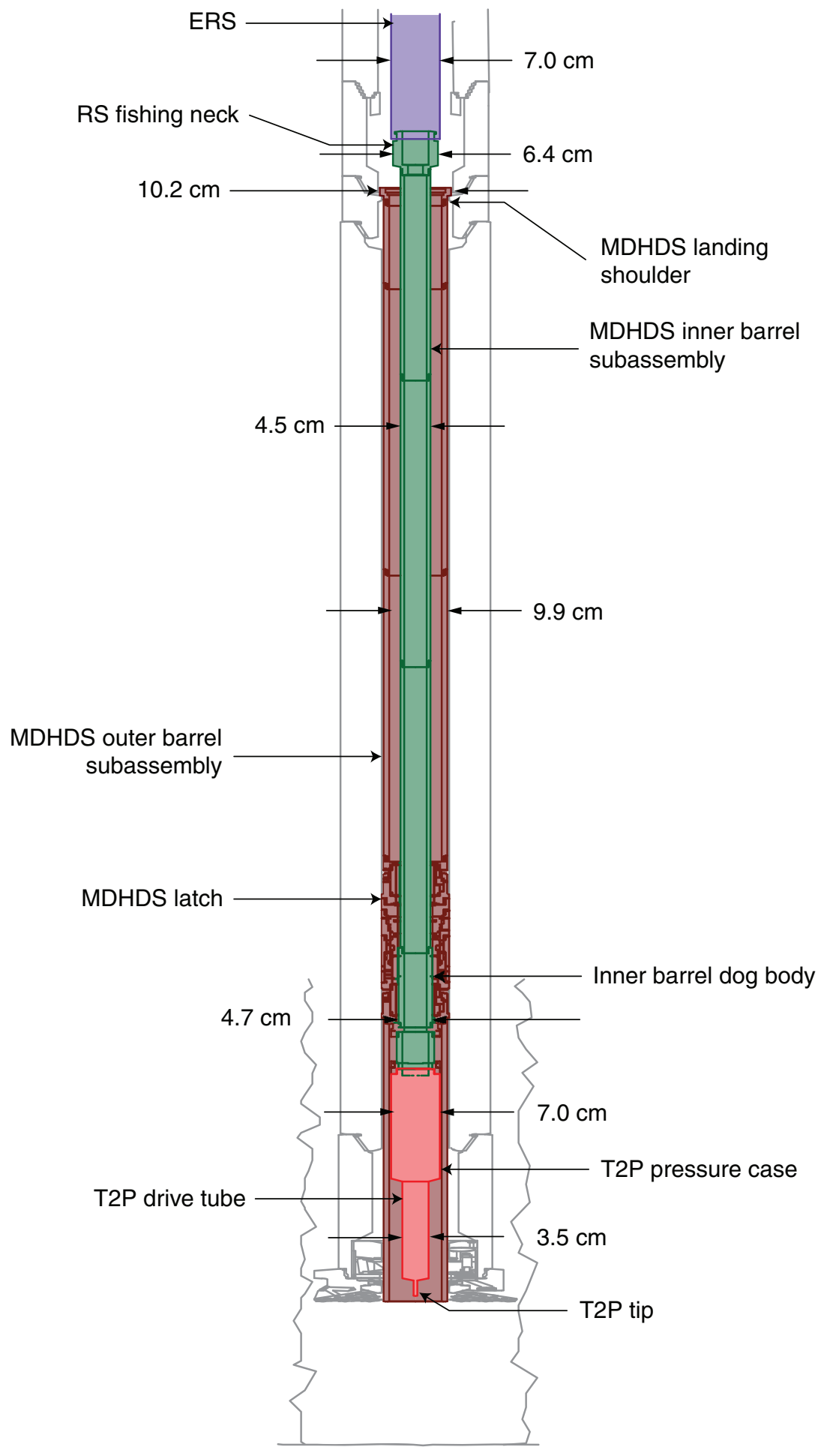


Figure F13. Diagram of the telemetry surface control panel (TSCP), a standard Schlumberger Vector 7-46P seven-conductor armored cable for use in logging operations, a Schlumberger logging equipment cablehead (LEH-QT) that makes the physical and electrical connections from the wireline logging cable to the downhole tool string, and the multiFunction Telemetry Module (MFTM; captures the data stream from the probe and broadcasts it to the surface panel) that make up telemetry system components of the Motion Decoupled Hydraulic Delivery System, Expedition 342. The MFTM attaches directly to the electronic RS (ERS).
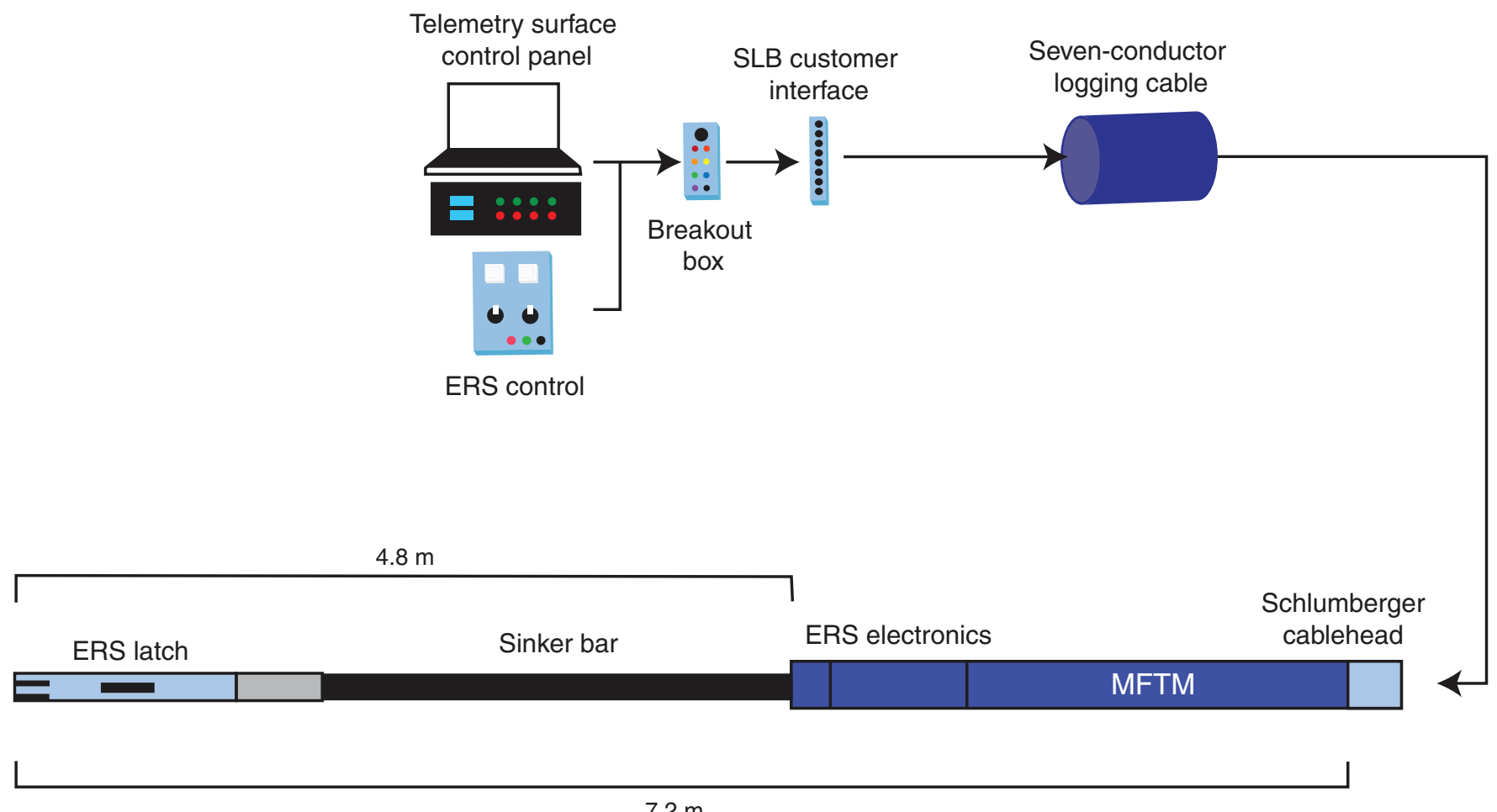

$7.2 \mathrm{~m}$ 
Figure F14. Photograph and diagram of the components of the multiFunction Telemetry Module, Expedition 342.
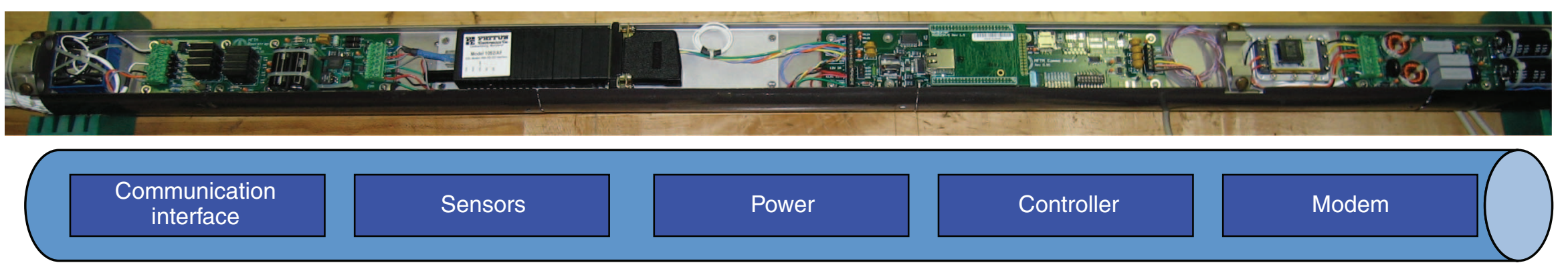
Figure F15. Photograph of the electronic RS (ERS) tool electronics housing (left) and the ERS latch motor housing (right) (see bottom of Fig. F13), Expedition 342. The sinker bar is not shown, but the electronics cable that connects the ERS motor to the ERS electronics and runs through the sinker bar is shown.

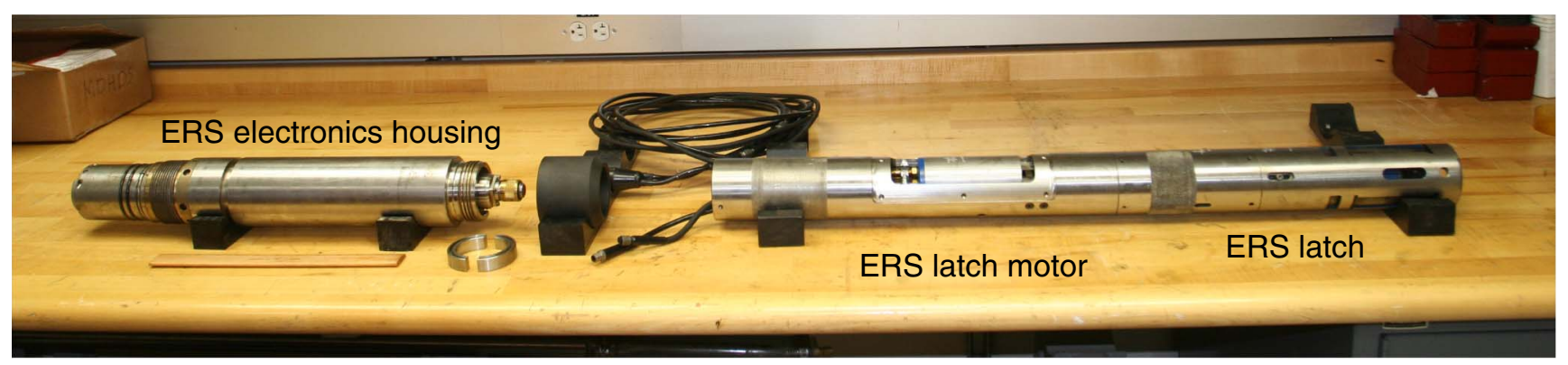


Figure F16. Photograph of the electronic RS (ERS) sinker bar, Expedition 342.

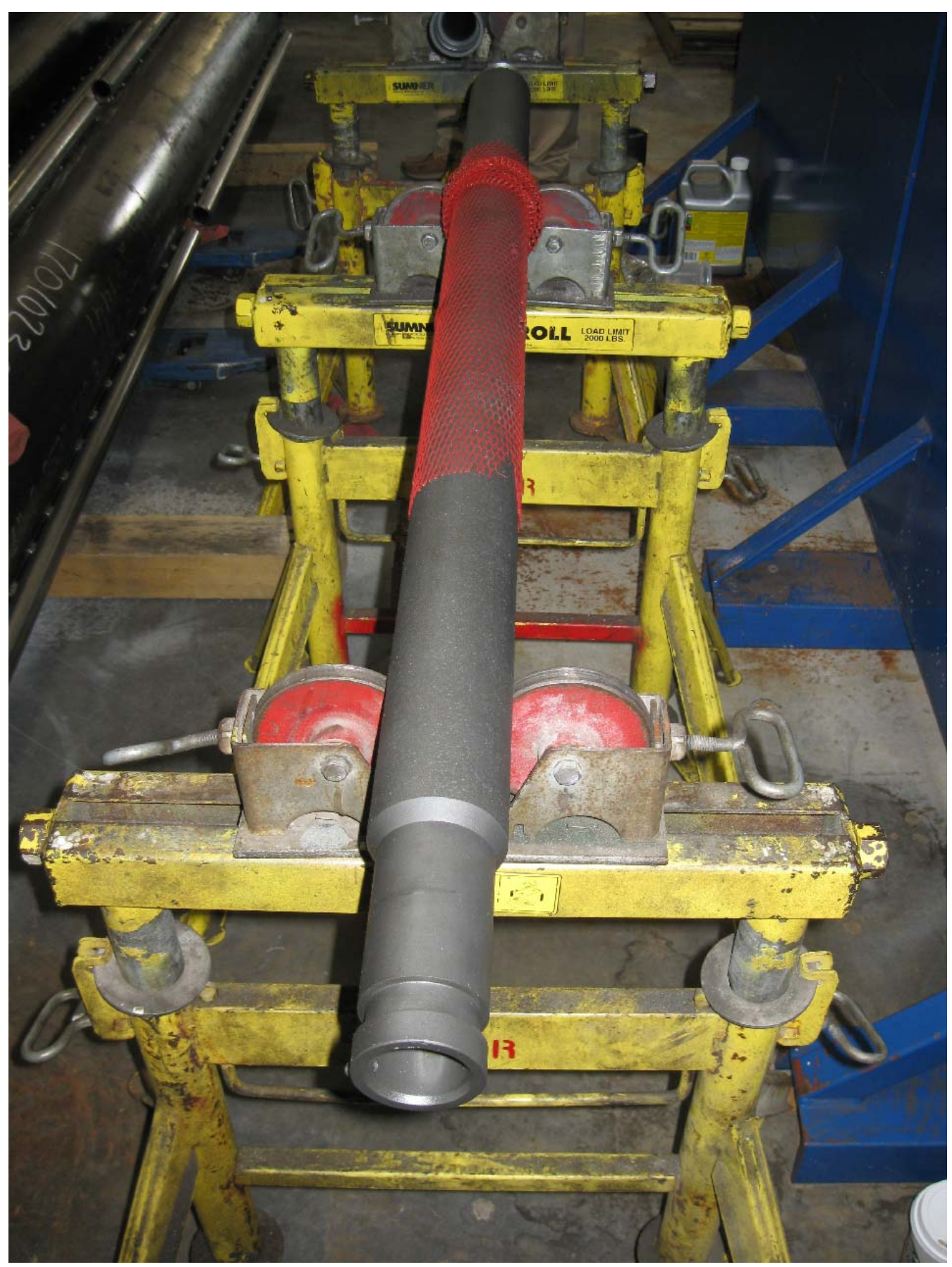


Figure F17. Photograph of the electronic RS (ERS) latch, Expedition 342.

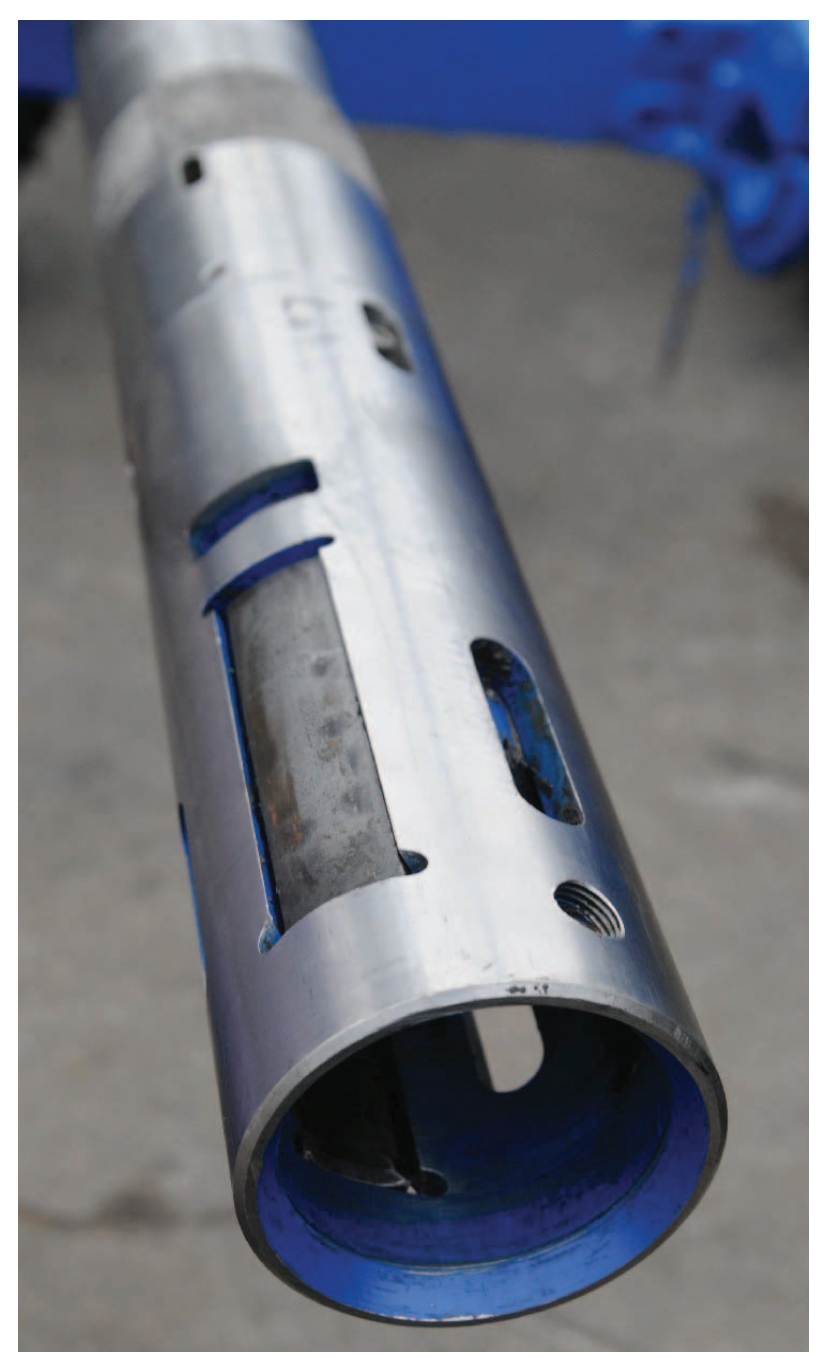


Figure F18. Diagram of the Motion Decoupled Hydraulic Delivery System inner barrel subassembly, Expedition 342.

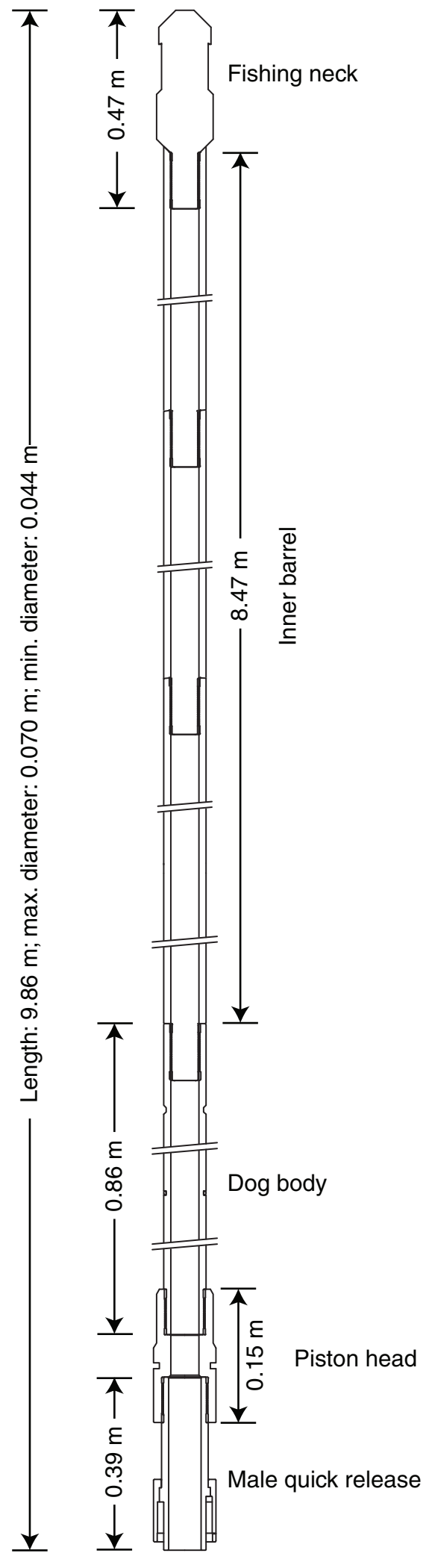


Figure F19. Diagram of the Motion Decoupled Hydraulic Delivery System outer barrel subassembly, Expedition 342. XCB = extended core barrel.

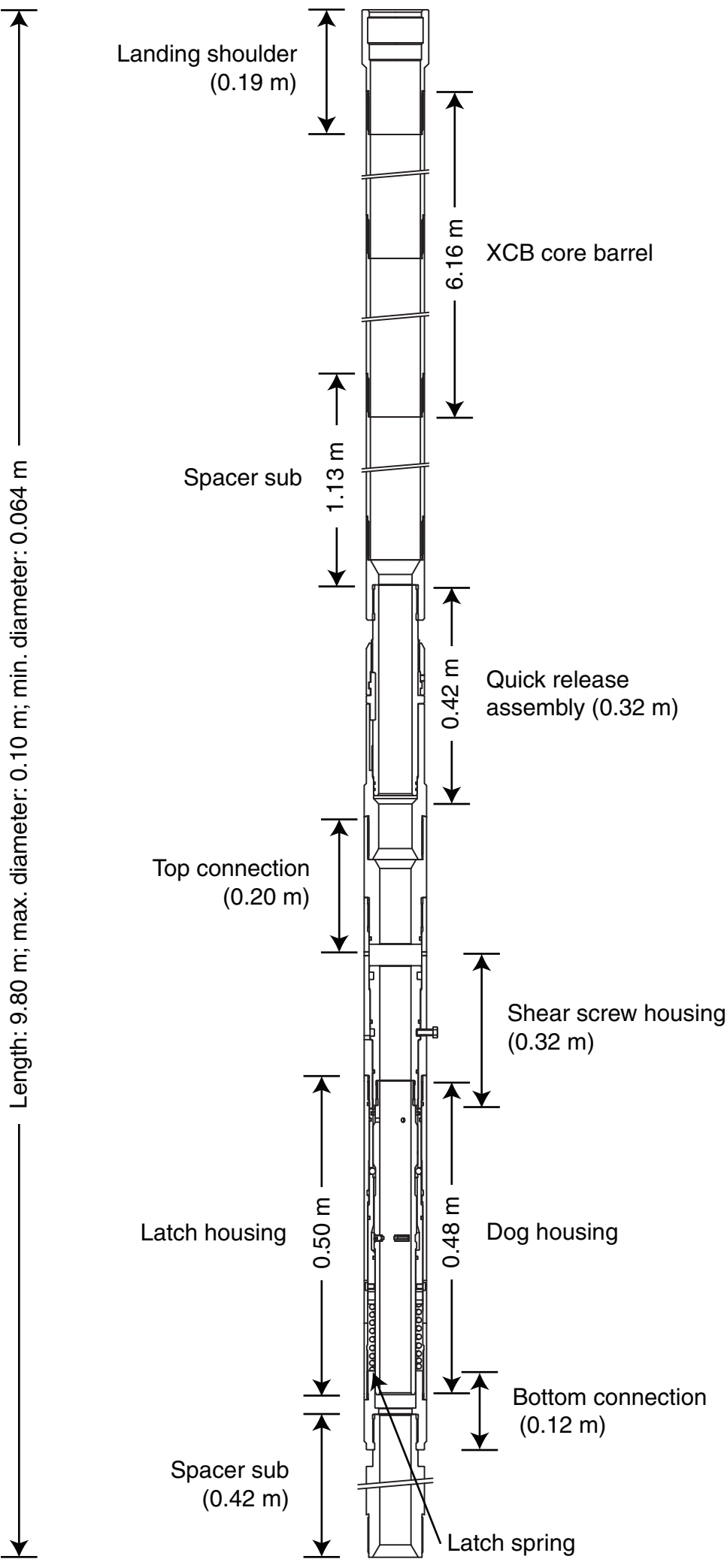


Figure F20. Photograph of the Motion Decoupled Hydraulic Delivery System (MDHDS) inner barrel and outer barrel subassemblies, Site U1402.

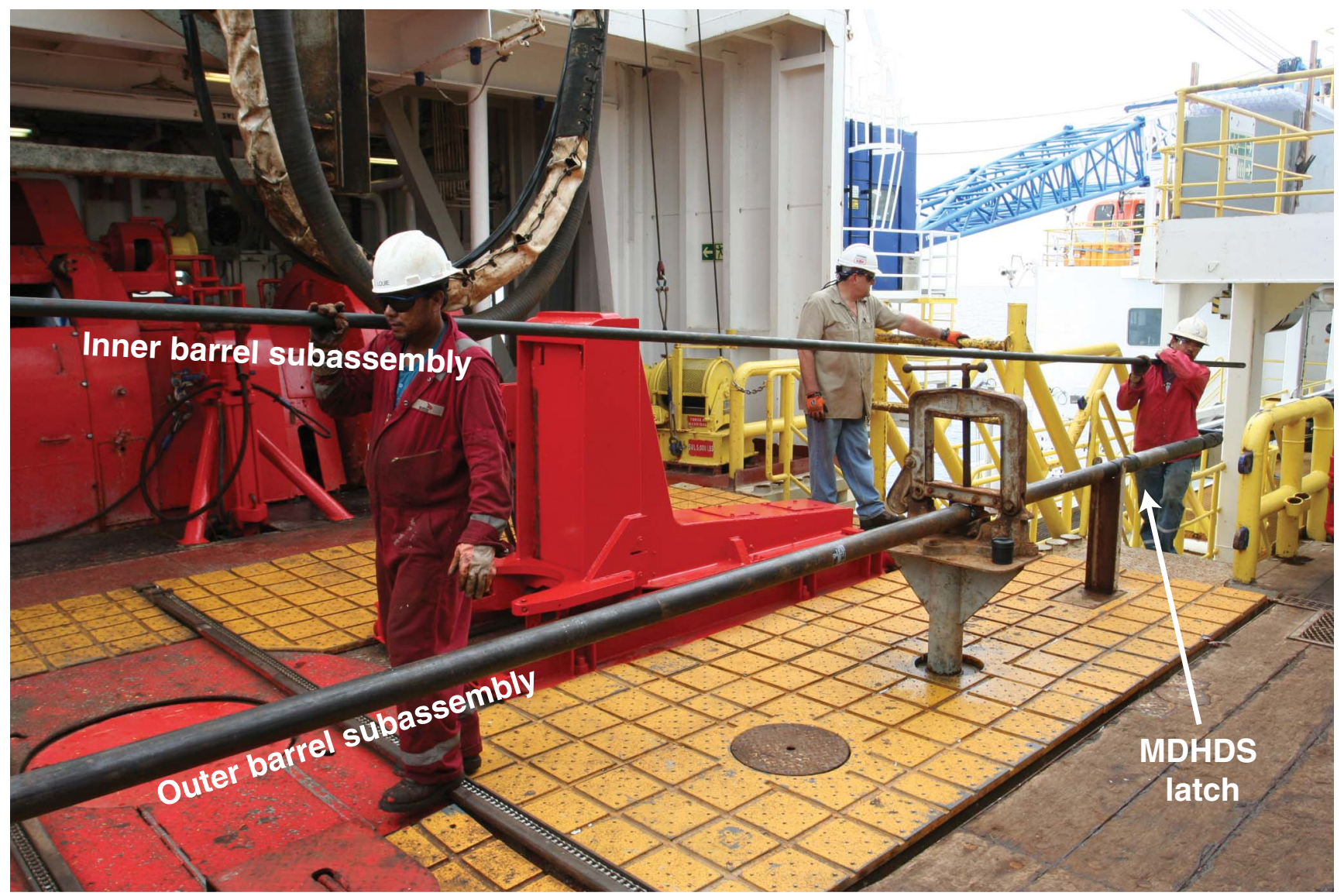


Figure F21. Photograph of the Motion Decoupled Hydraulic Delivery System (MDHDS) latch and latching tool, Site U1402. The latch is set on the rig floor, which fixes the inner barrel subassembly to the outer barrel subassembly. When the drill string is pressurized, the latch is released and the inner barrel slides freely from the outer barrel.

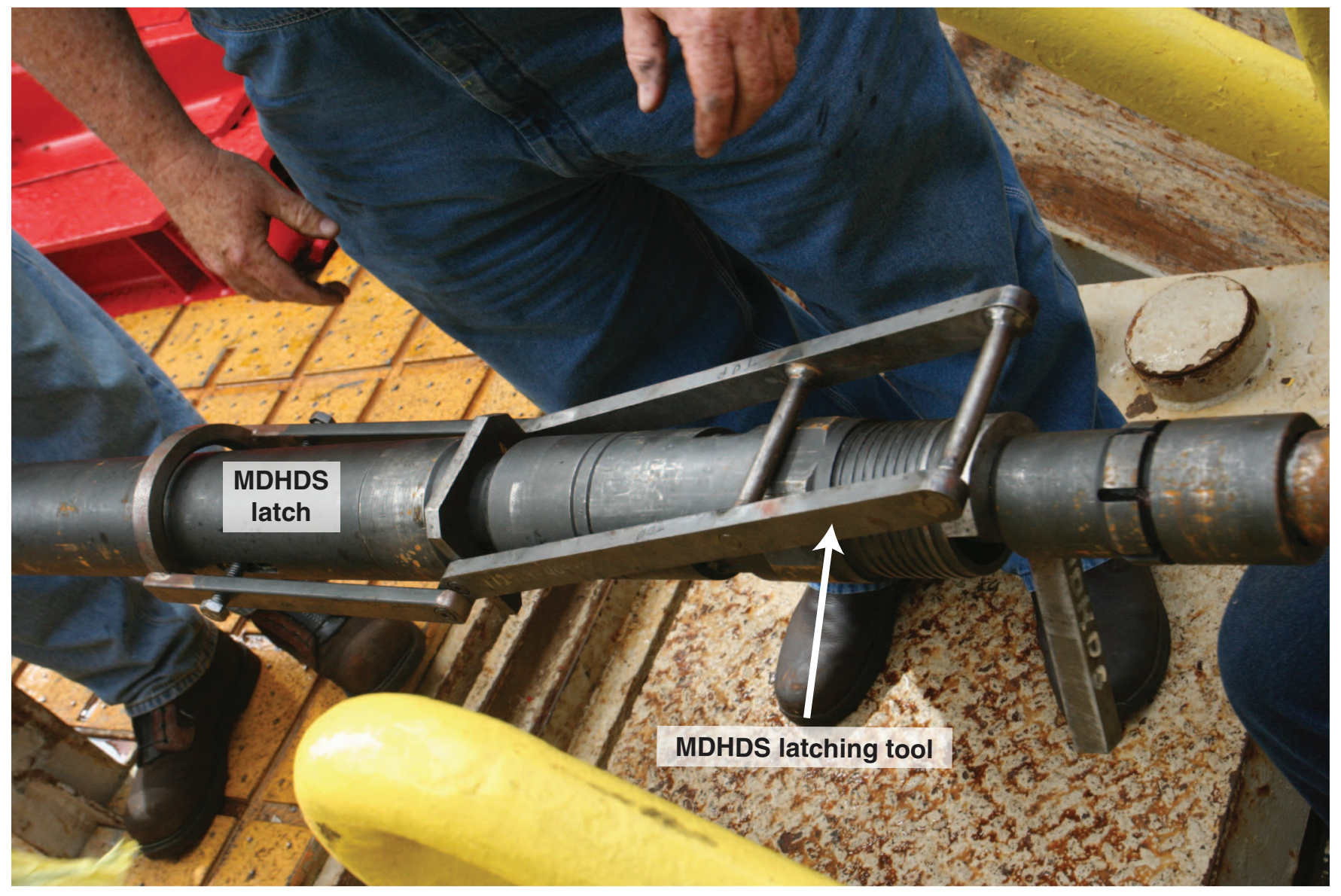


Figure F22. Diagrams of the Motion Decoupled Hydraulic Delivery System latch mechanism, Site U1402. A. After the latch is locked, the shear screws, lock balls, and dogs hold the shear screw housing, latch piston, and inner barrel subassembly (IBS), respectively, in place. B. Once the drill string is pressurized, the shear screws fail, allowing the shear screw housing and dog housing to shift downward, aligning the lock ball with the unlocked relief groove and completely compressing the spring. At this point, the latch is mechanically free to shift vertically but is unable to do so because of the drill string pressure. C. After the drill string pressure is completely bled off, the latch piston is driven upward by the latch spring, aligning the dog with the dog relief groove. D. At this point the IBS is free to descend, although friction between dogs and the dog body (of the IBS) may keep it from doing so until the drill string is repressurized. Not all components drawn to scale.

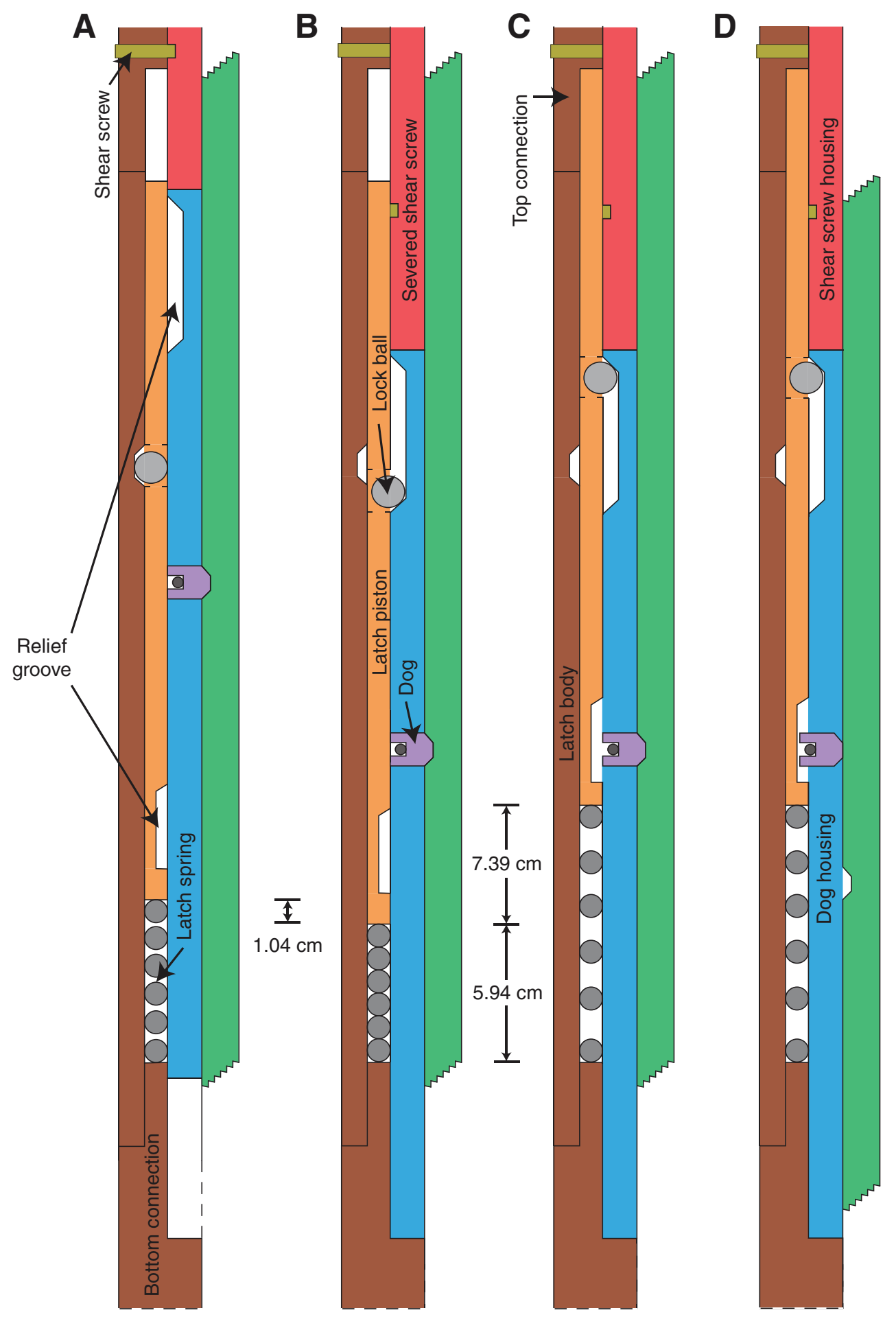


Figure F23. Diagram of the communications tether system, Site U1402. ERS = electronic RS, T2P = temperaturedual-pressure probe.

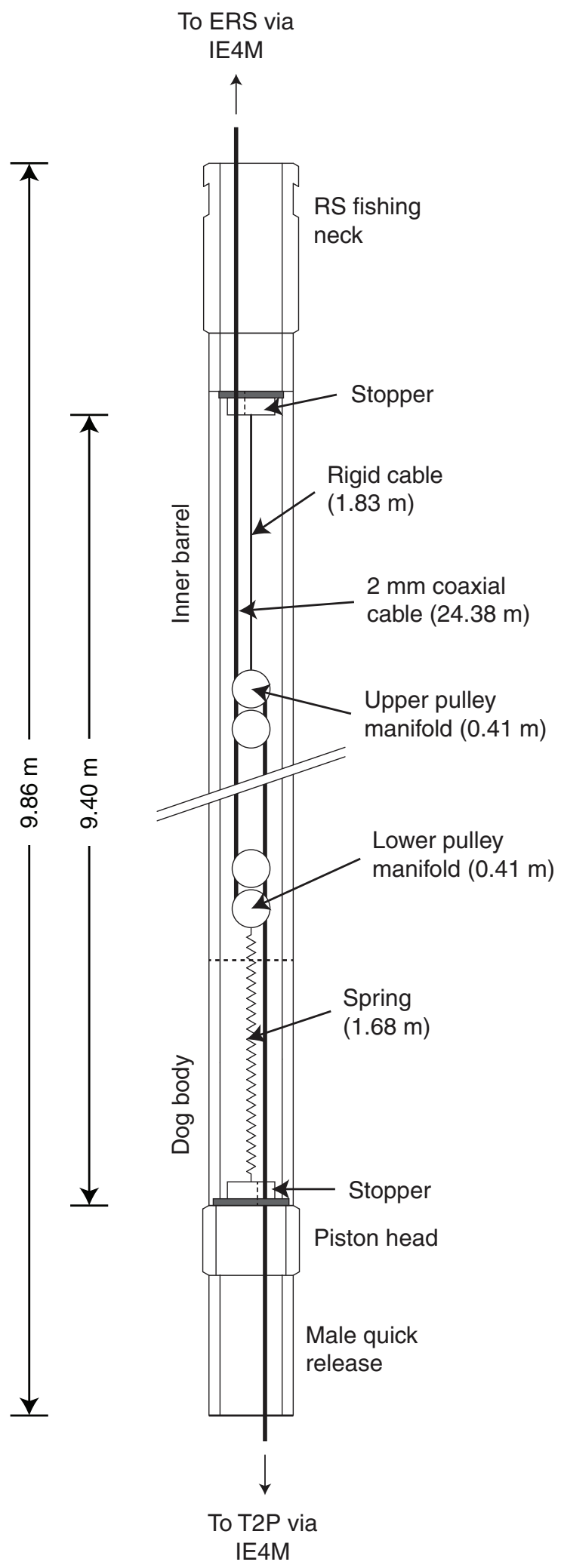


Figure F24. Photograph of the inner barrel subassembly (IBS) lying inside the outer barrel subassembly, Site U1402. The RS fishing neck of the IBS is shown at the lower left. On the right, the electronic RS (ERS) tool is connected to the Multifunction Telemetry Module, which is connected to the Schlumberger logging line. The ERS latch is at the bottom of the ERS assembly.

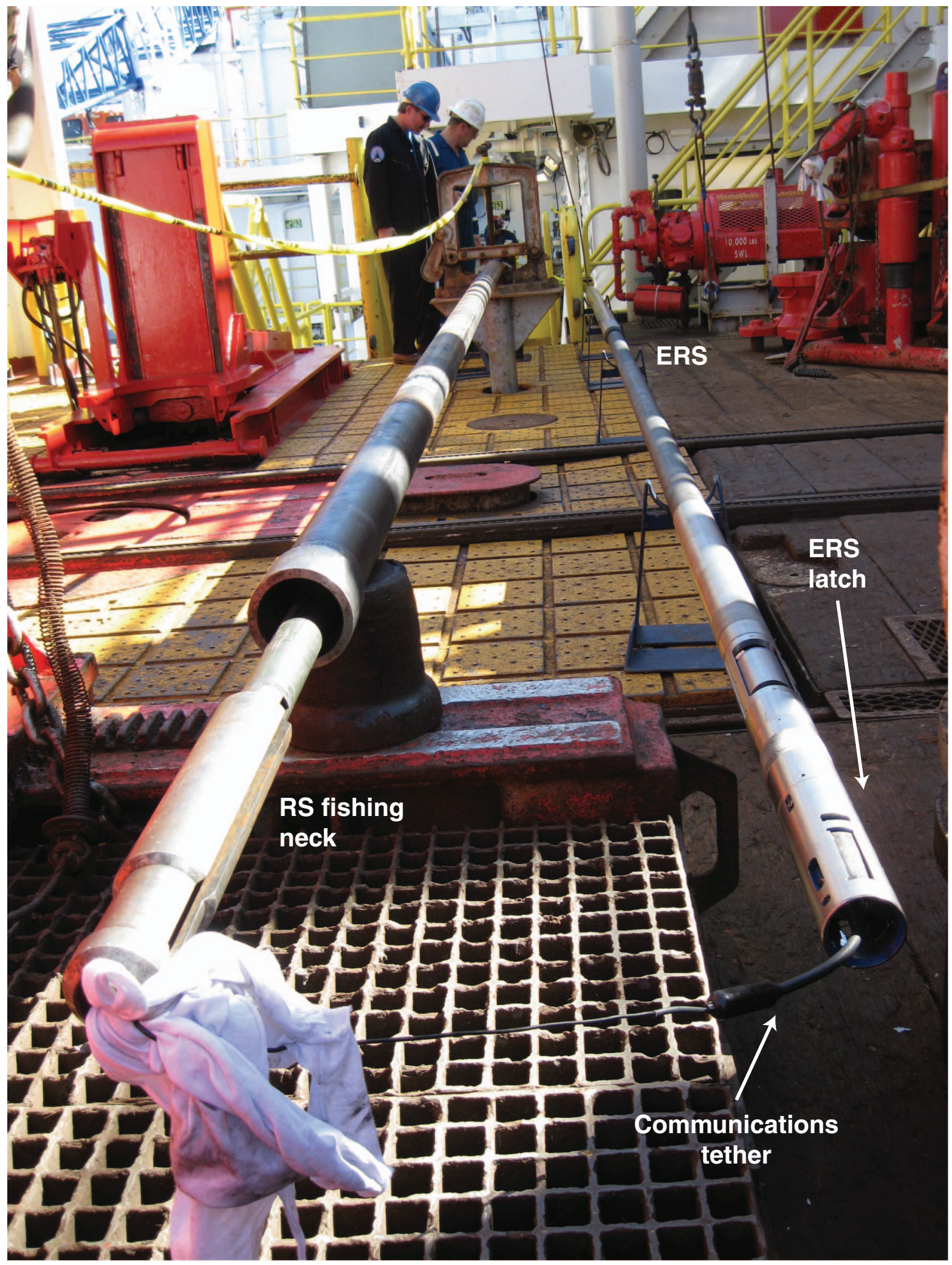


Figure F25. Photograph of the Motion Decoupled Hydraulic Delivery System being lifted into place by the wench using a lifting clamp attached just below the RS fishing neck, Site U1402.

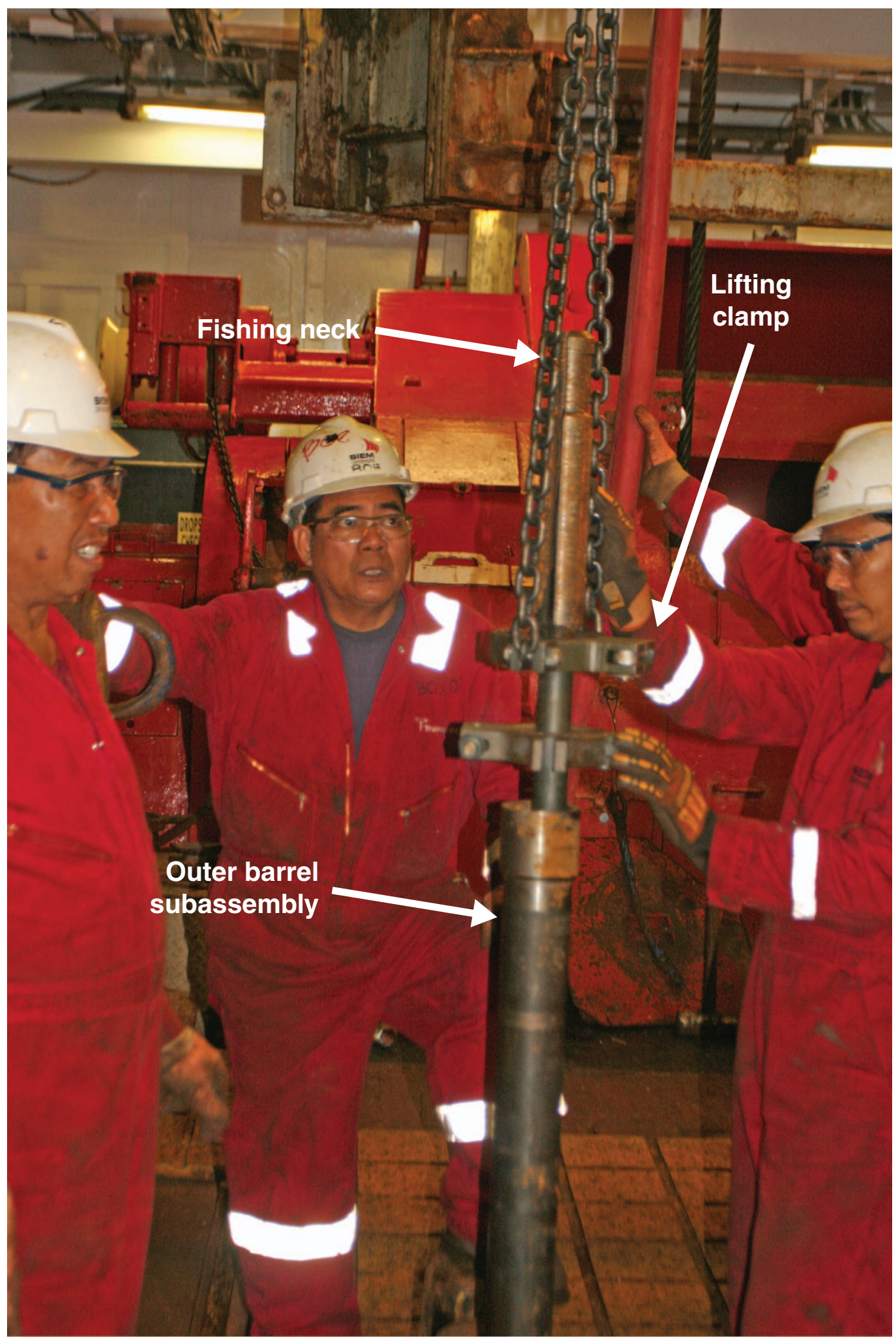


Figure F26. Photograph of the Motion Decoupled Hydraulic Delivery System being placed in the drill string, resting on the lifting clamp until the ERS is attached, Site U1402.

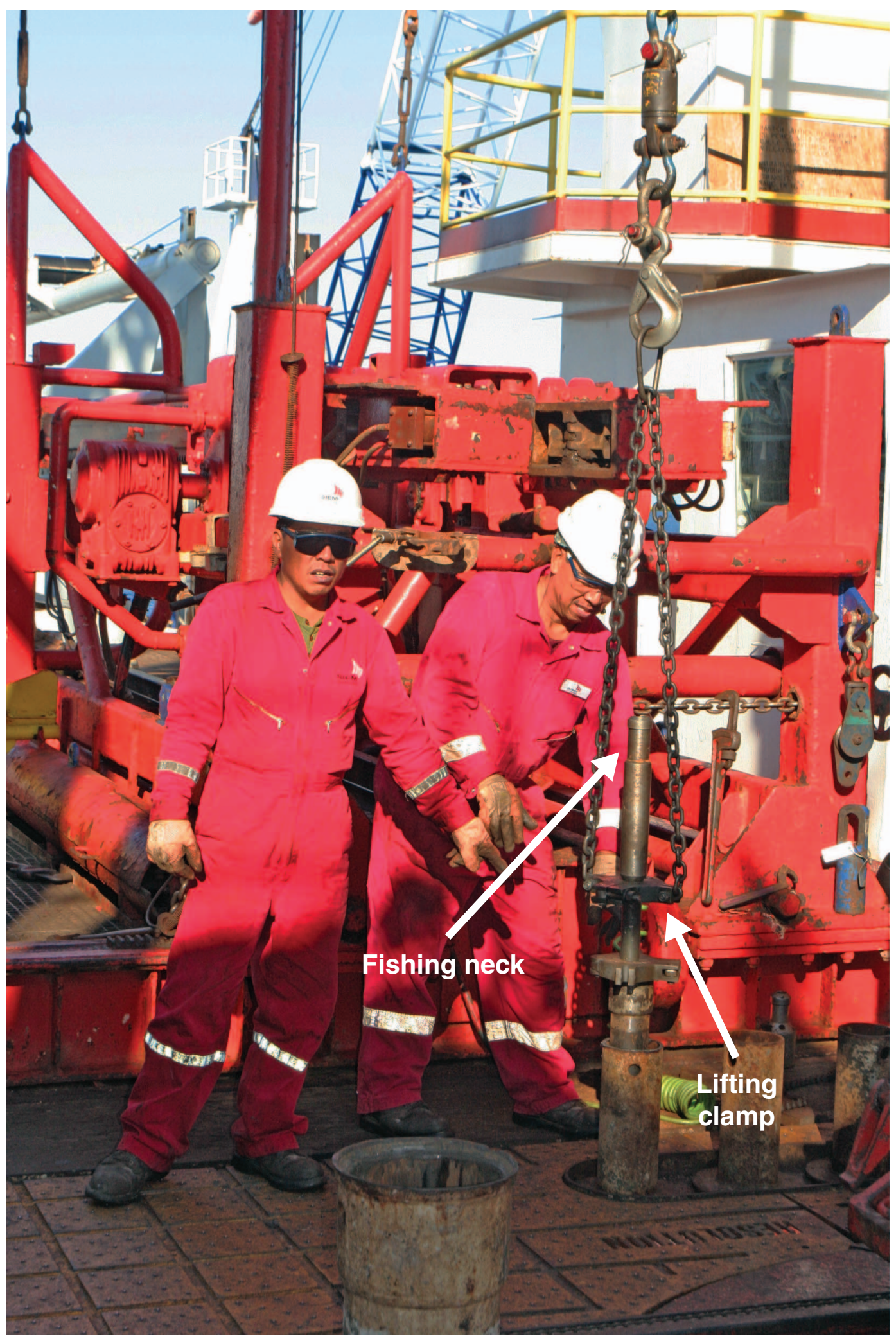


Figure F27. Photograph of the IE4M connector from the communications tether connecting to the electronic RS (ERS) tool, Site U1402.

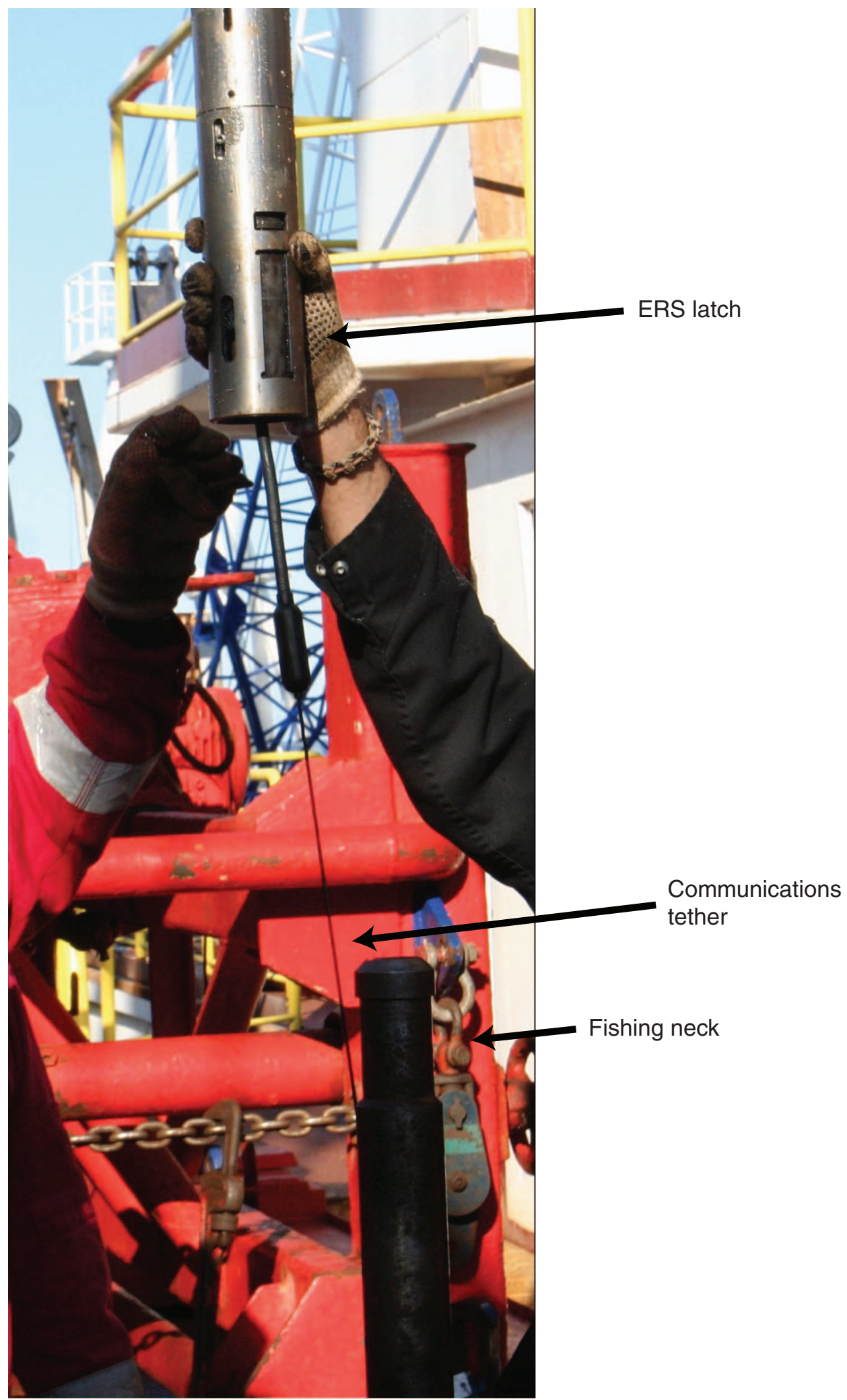


Figure F28. Diagram of the stages of the Motion Decoupled Hydraulic Delivery System (MDHDS) deployment, Site U1402. A. The MDHDS is rested on the bottom-hole assembly (BHA). B. The electronic RS (ERS) tool unlatches and is raised $3.0 \mathrm{~m}$. C. The drill string is pressurized, the tool is unlatched, and the tool is driven $\sim 2.9 \mathrm{~m}$ out of the flapper tube until circulation is established. D. The BHA is raised $2.0 \mathrm{~m}$, giving the MDHDS approximately $\pm 3.0 \mathrm{~m}$ of heave leeway. $\mathrm{E}$. The ERS is lowered and relatched. F. The MDHDS is brought back to the surface.
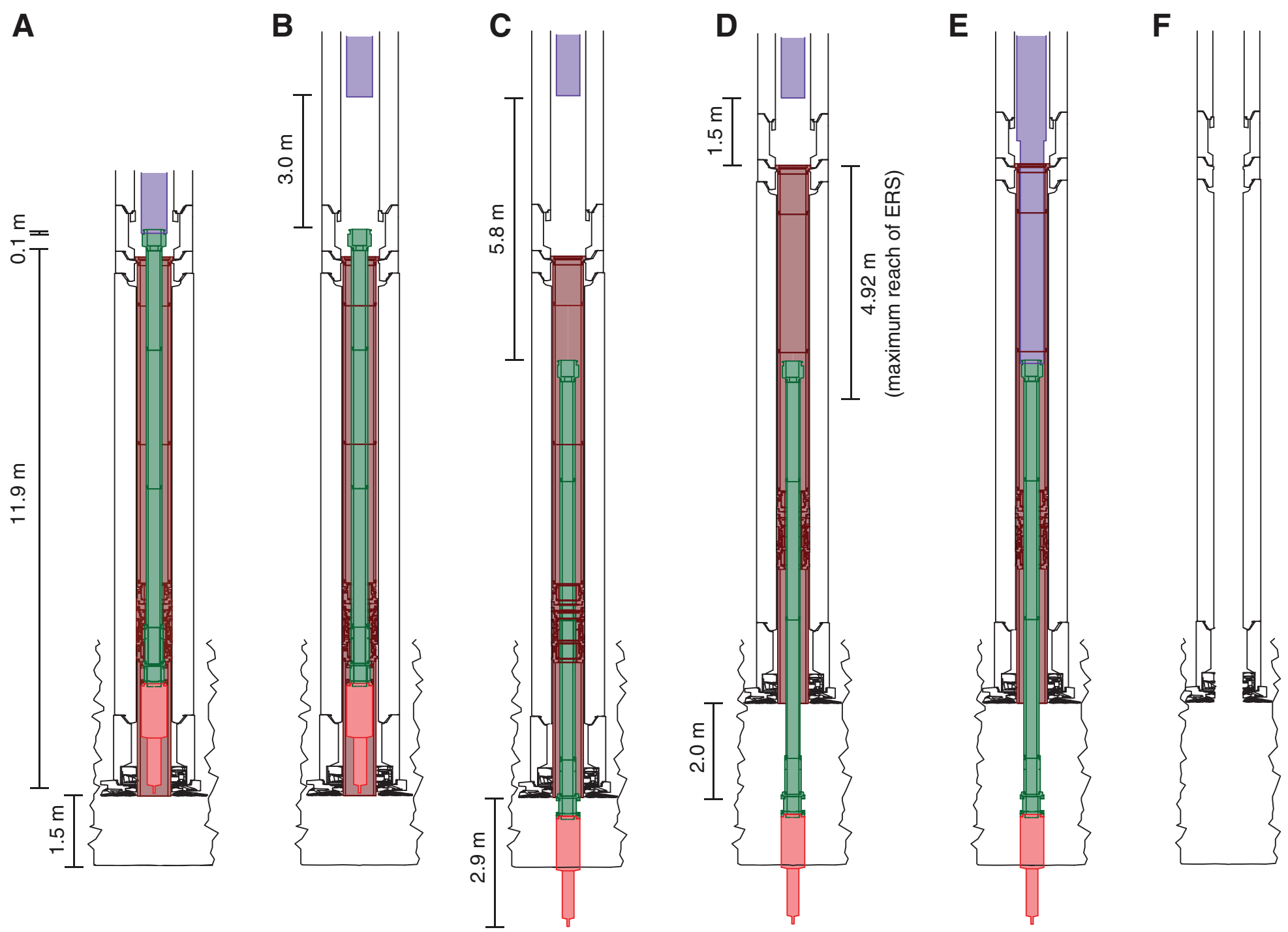
Figure F29. Diagram showing the maximum reach $(4.92 \mathrm{~m})$ of the electronic RS (ERS) tool into the Motion Decoupled Hydraulic Delivery System (MDHDS), Site U1402.

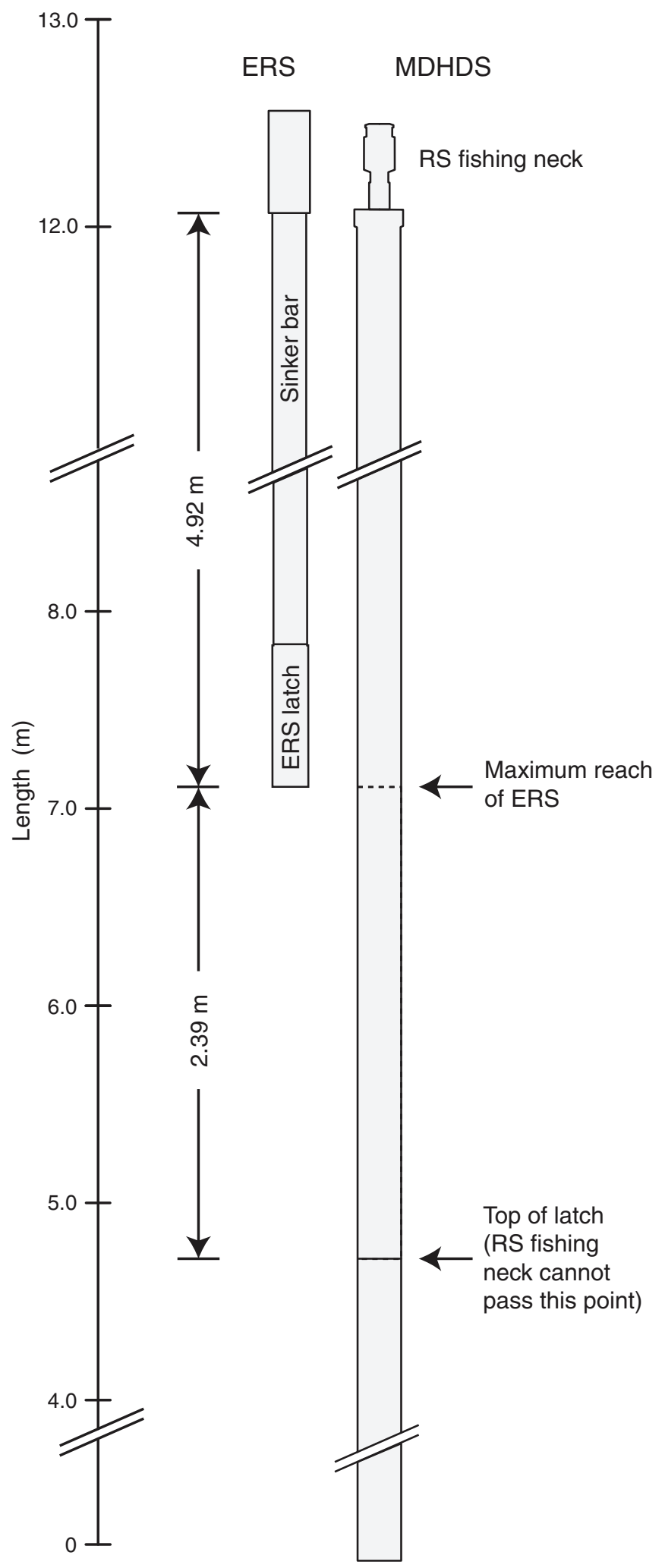


Figure F30. Plot of temperature-dual-pressure probe tip pressure, shaft pressure, tip temperature, and vertical acceleration during Motion Decoupled Hydraulic Delivery System Deployment 1, Site U1402.

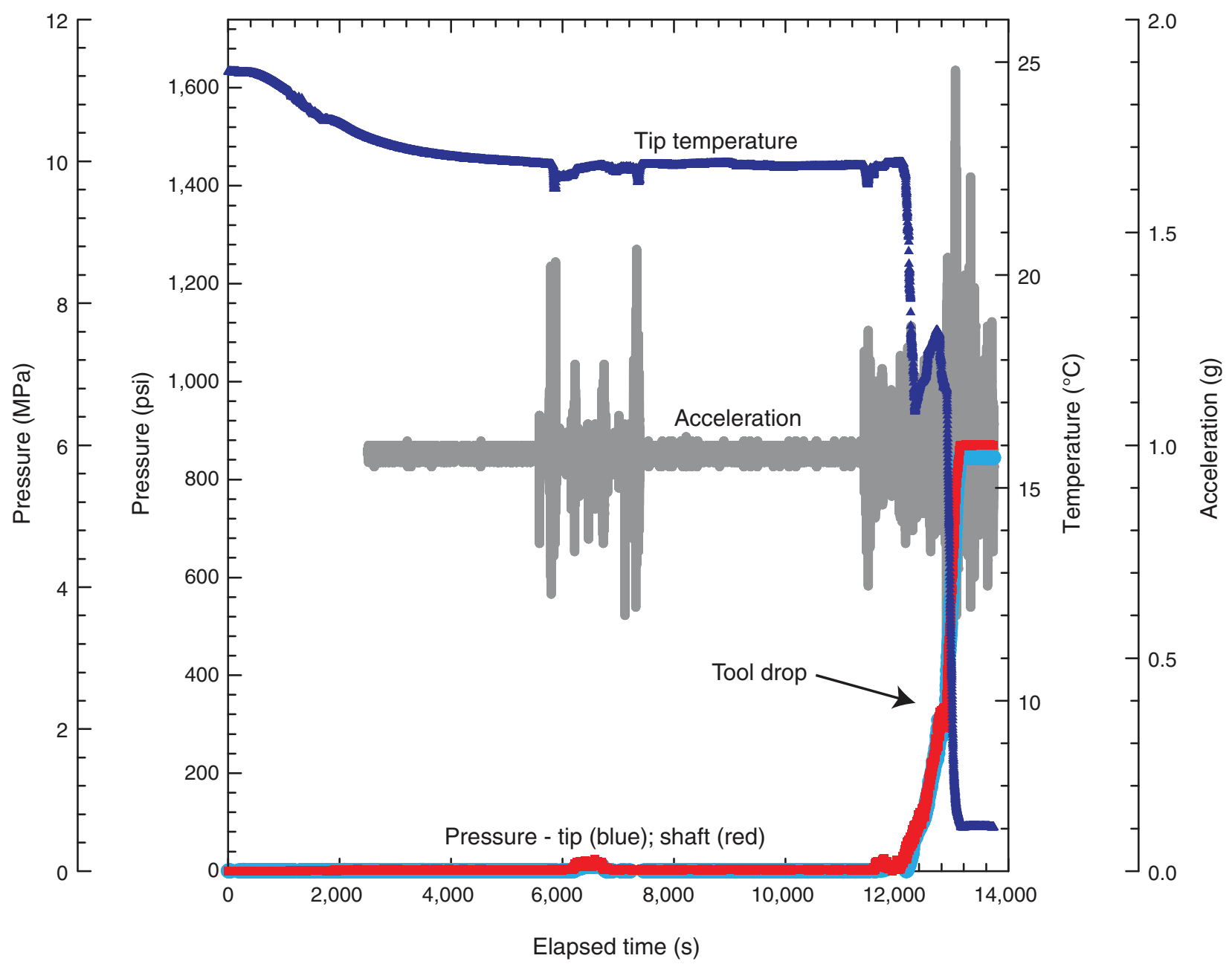


Figure F31. Plot of temperature-dual-pressure probe pressure data with wireline depth and tension showing the point when the electronic RS (ERS) tool dropped the Motion Decoupled Hydraulic Delivery System at 12,900 s, Site U1402.

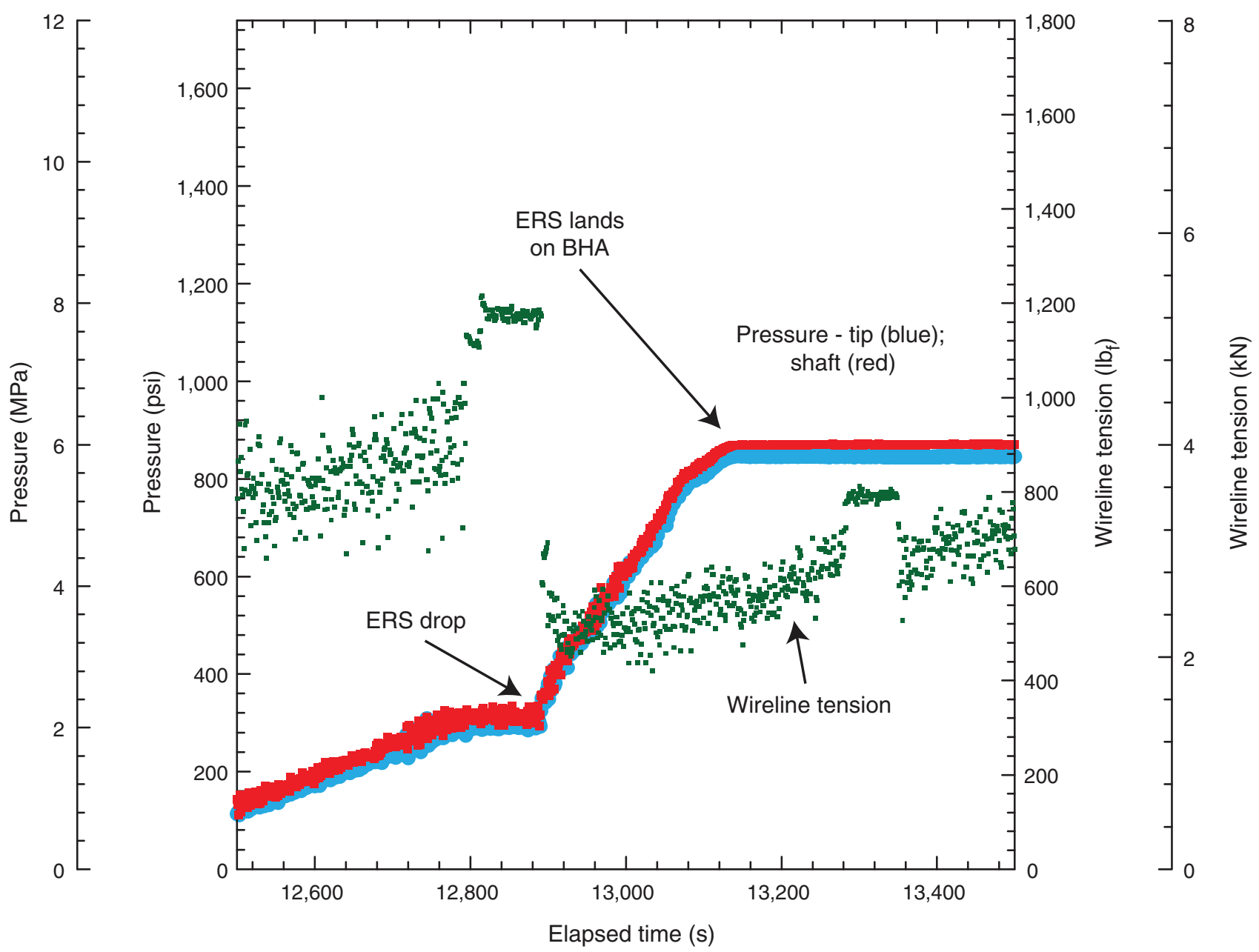


Figure F32. Plot of the results from three attempts to unlatch the Motion Decoupled Hydraulic Delivery System (MDHDS) during Deployment 1, Site U1402. All three attempts were unsuccessful. We subsequently interpreted that the pressure was raised enough to shear the shear pins, but the pressure was not subsequently reduced enough to allow the spring to expand within the MDHDS latch. As discussed in the text, the standpipe pressure had to drop to $<0$ in order for the spring to expand against the hydrostatic pressure within the drill string.

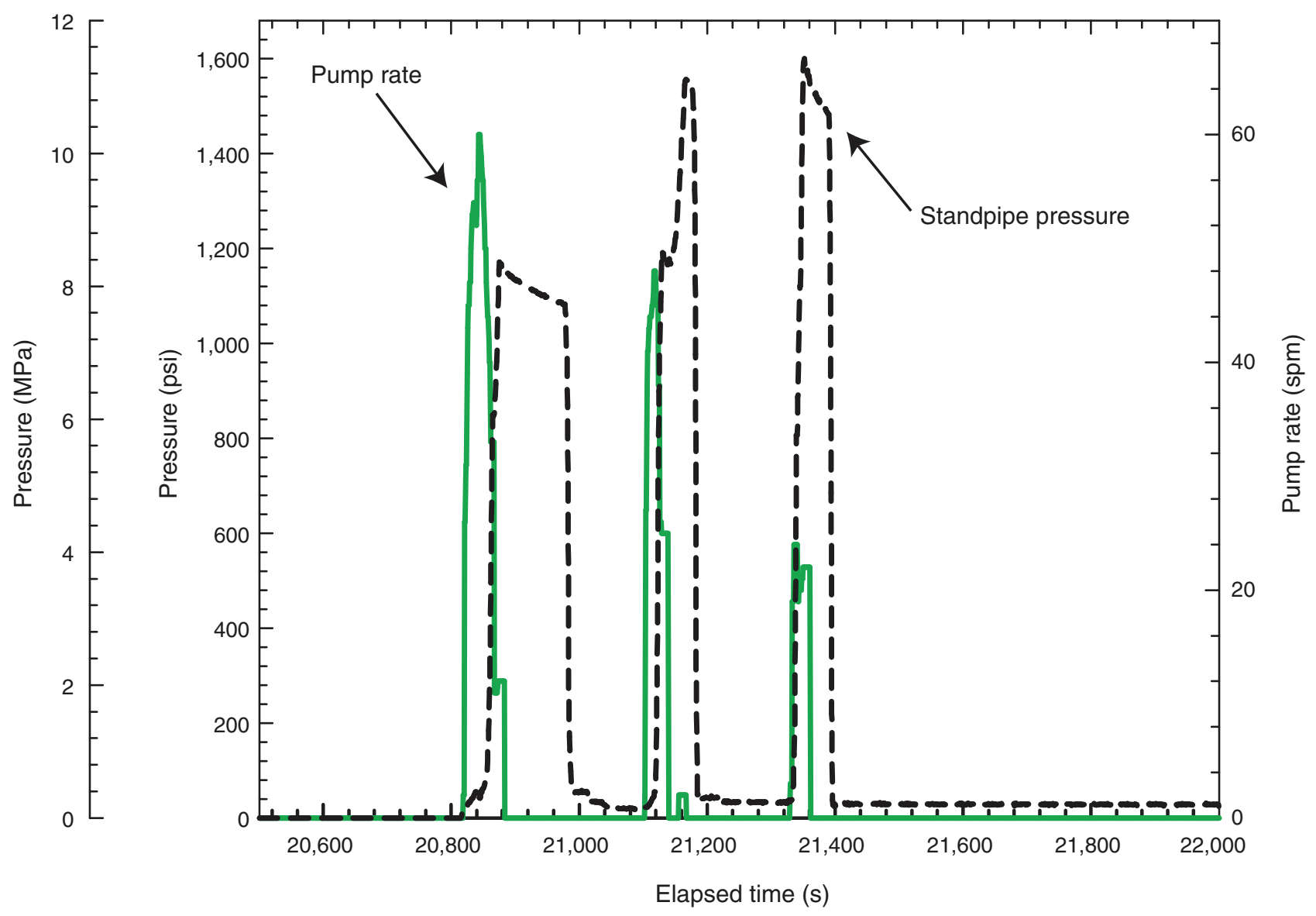


Figure F33. Plot of complete temperature-dual-pressure probe pressure, temperature, and acceleration data from Deployment 2, Site U1402. Letters correspond to Table T11.

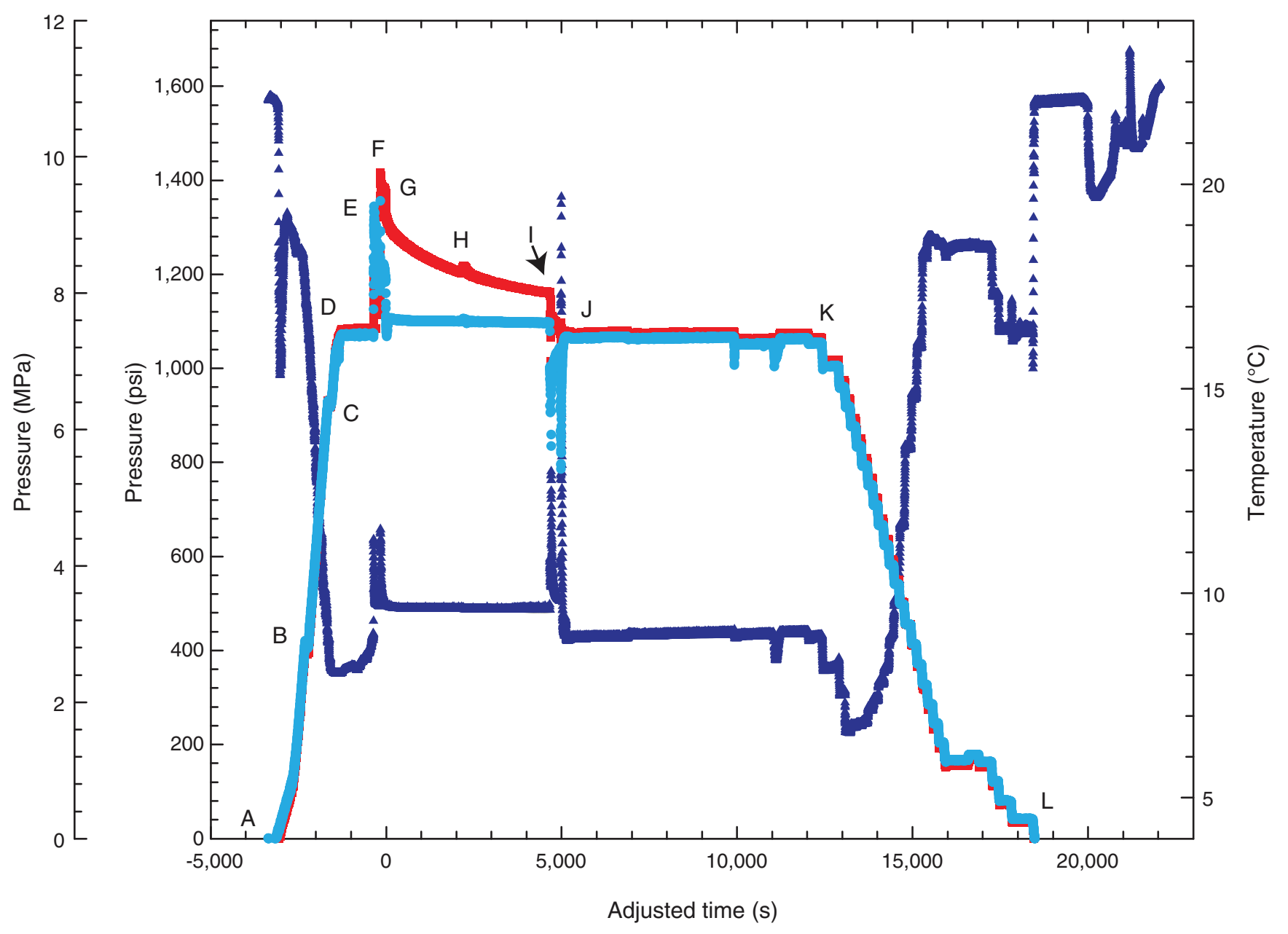


Figure F34. Plot of the results from three attempts to unlatch the Motion Decoupled Hydraulic Delivery System (MDHDS) during Deployment 2, Site U1402. To unlatch the drill string, pressure is first raised to between 1000 and $1500 \mathrm{psi}$, and pressure is then reduced. We interpret that the first two attempts were unsuccessful because the standpipe pressure was not reduced enough. During the last pressurization, the standpipe pressure was adequately reduced, which allowed the spring within the MDHDS to expand. Letters correspond to Table T11.

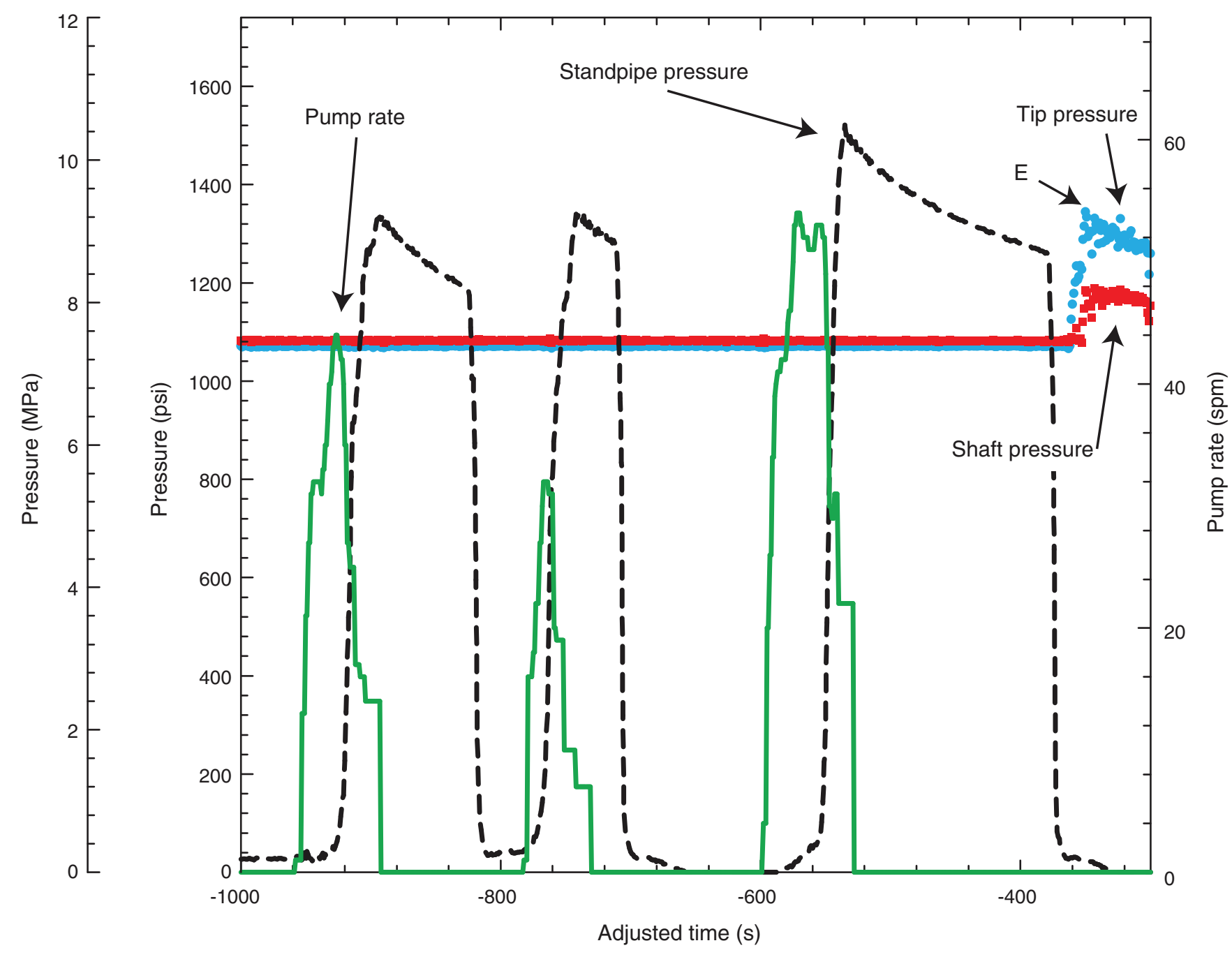


Figure F35. Plot of the results from successful attempt to unlatch the Motion Decoupled Hydraulic Delivery System (MDHDS) during Deployment 2, Site U1402. At approximately -220 s, the pump rate was increased to drive the penetrometer into the formation. As a result, the standpipe pressure increased and the shaft pressure recorded an abrupt increase (F). The pumps were turned off at $\mathrm{G}$, and pressure dissipation began. Letters correspond to Table T11.

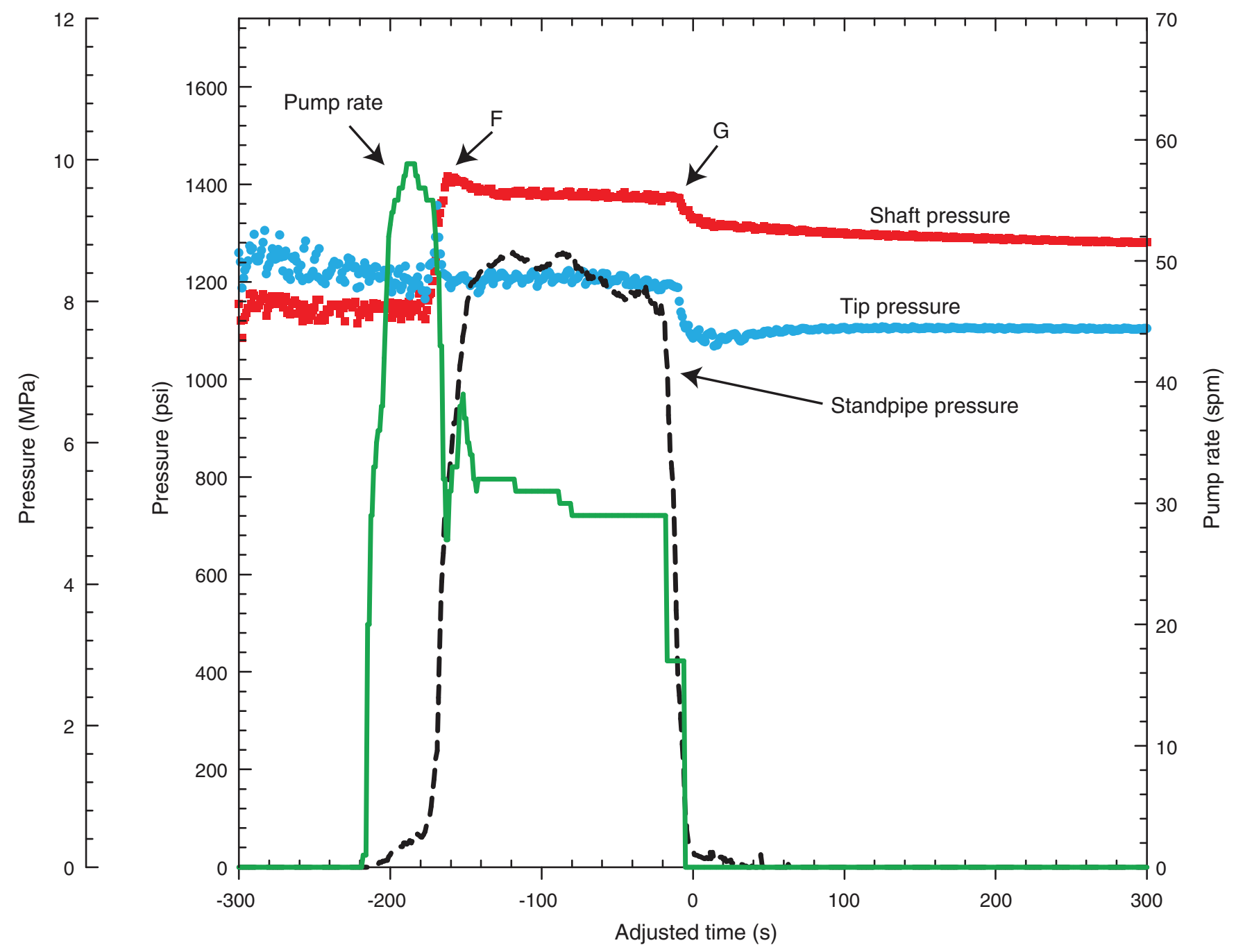


Figure F36. Plots of pressure, temperature, and vertical acceleration (top panel) and ship heave vs. time and vertical acceleration (bottom panel) recorded by the temperature-dual-pressure probe penetrometer, Site $\mathrm{U} 1402$. The tool is released and falls under its own weight at $\mathrm{E}$. The tool is driven into the formation at F. Pumps are turned off and dissipation begins at G. Despite significant ship heave, the penetrometer, which is embedded in the formation, records no movement during the dissipation phase. This indicates that the Motion Decoupled Hydraulic Delivery System has successfully decoupled from the penetrometer. Letters correspond to Table T11.

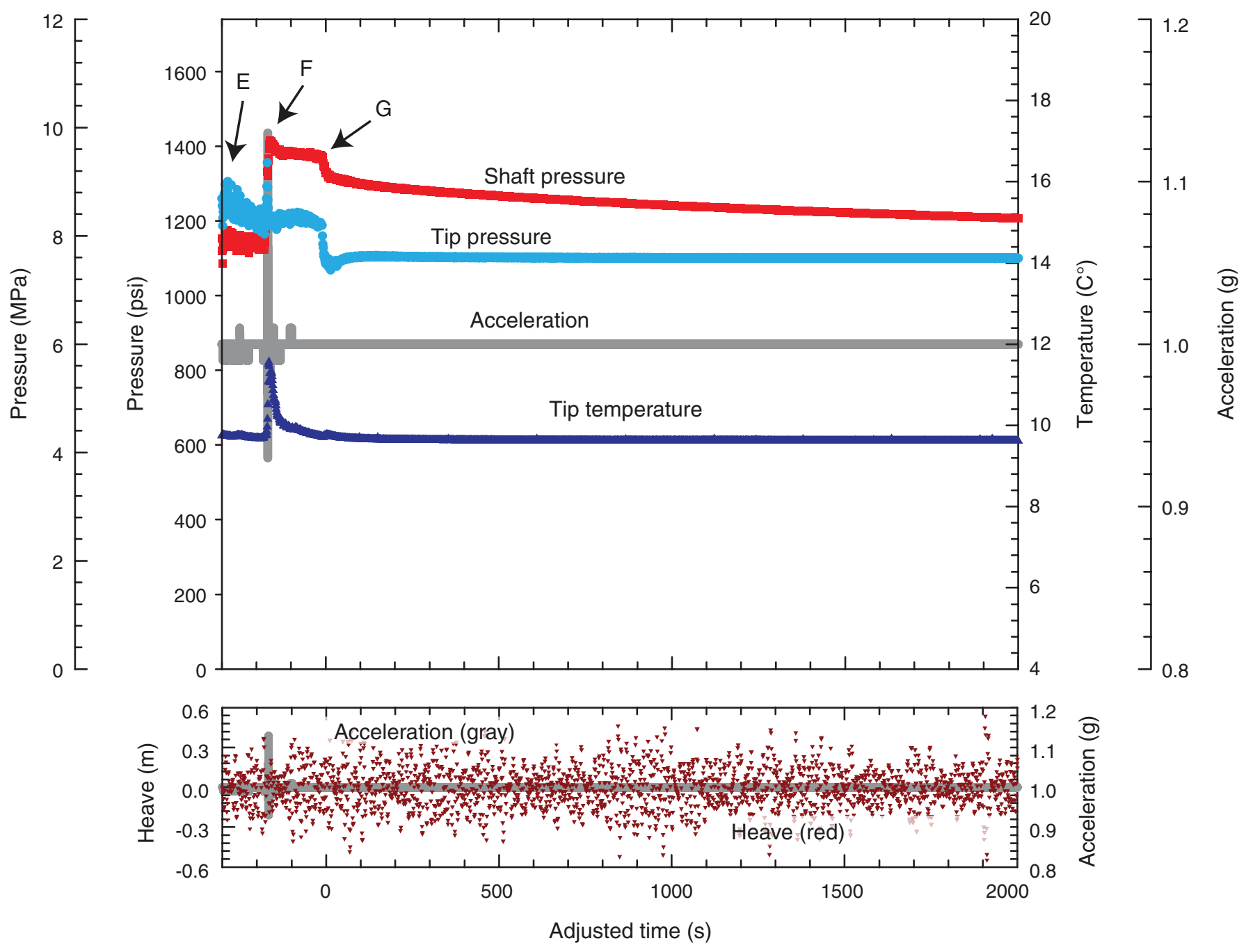


Figure F37. Plot of results of the end of Deployment 2, Site U1402. At $2040 \mathrm{~s}$, the pumps were turned on to establish circulation. A minor increase in the standpipe pressure indicated circulation was unimpeded. At 2130 $\mathrm{s}$, the pumps were turned off and were turned on again at $\sim 2150 \mathrm{~s}$. This time the standpipe pressure rose dramatically. In addition, the accelerometer recording acceleration in the vertical direction recorded a significant displacement $(\mathrm{H})$. At this point the tether failed.

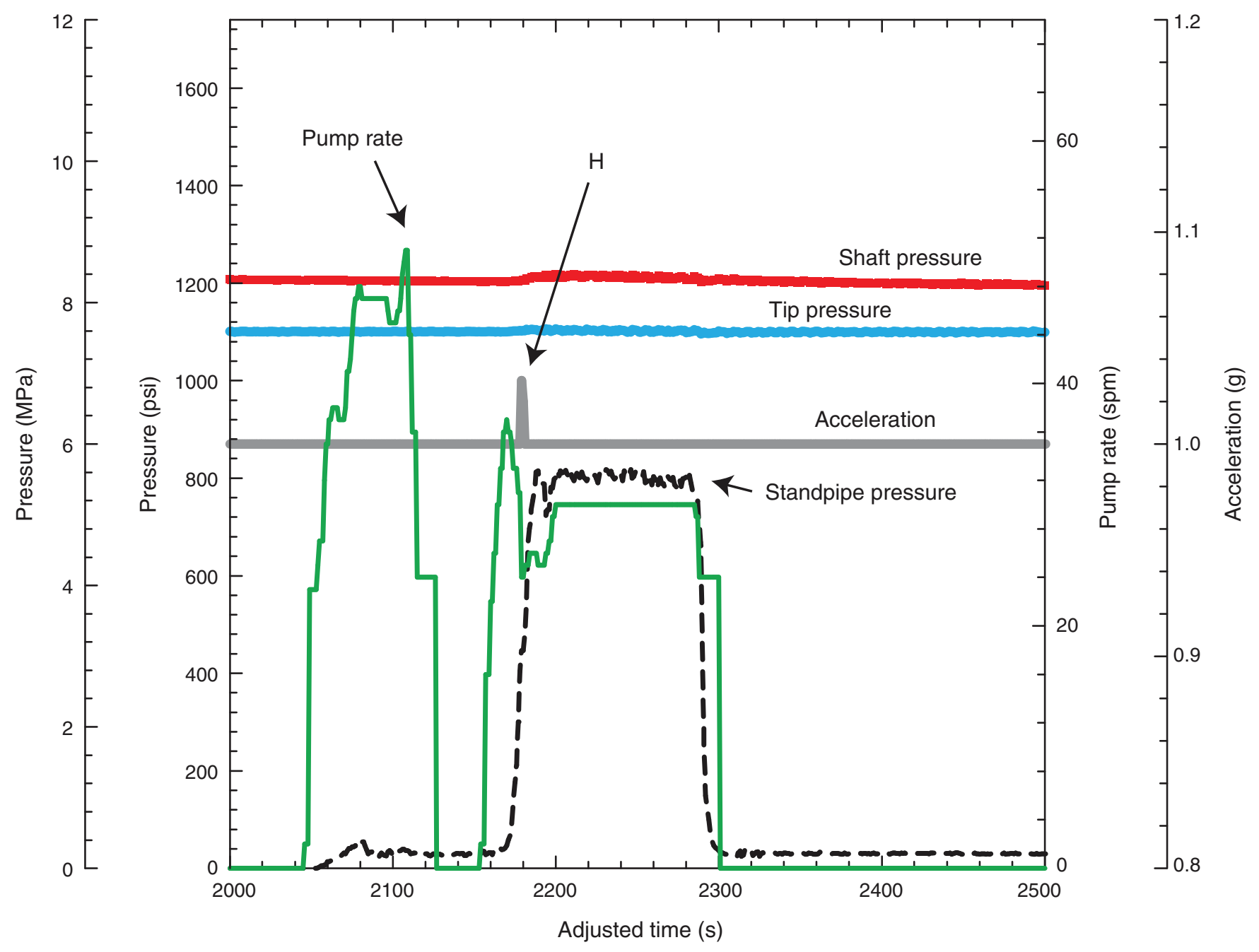


Figure F38. Plot of results from repeated attempts to recover the Motion Decoupled Hydraulic Delivery System with the electronic RS, Site U1402. Note the increase in wireline tension.

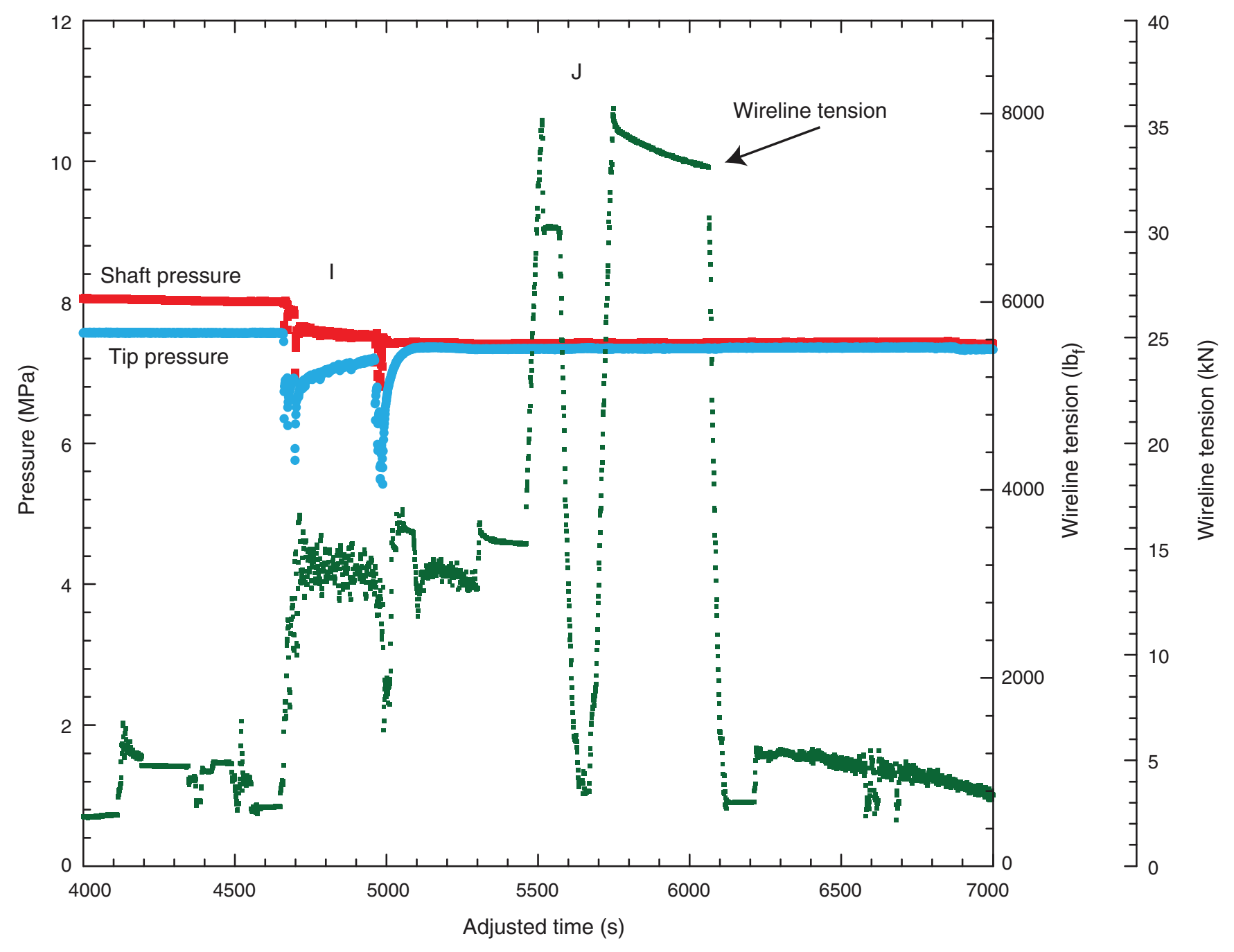


Figure F39. Plot of analysis of pressure and temperature dissipation data using the inverse time method for the last $600 \mathrm{~s}$ of data available (3900-4500 s), Site U1402. The shaft pressure is extrapolated to $7.66 \mathrm{MPa}$, the tip pressure is extrapolated to $7.53 \mathrm{MPa}$, and the tip temperature is extrapolated to $9.61^{\circ} \mathrm{C}$.

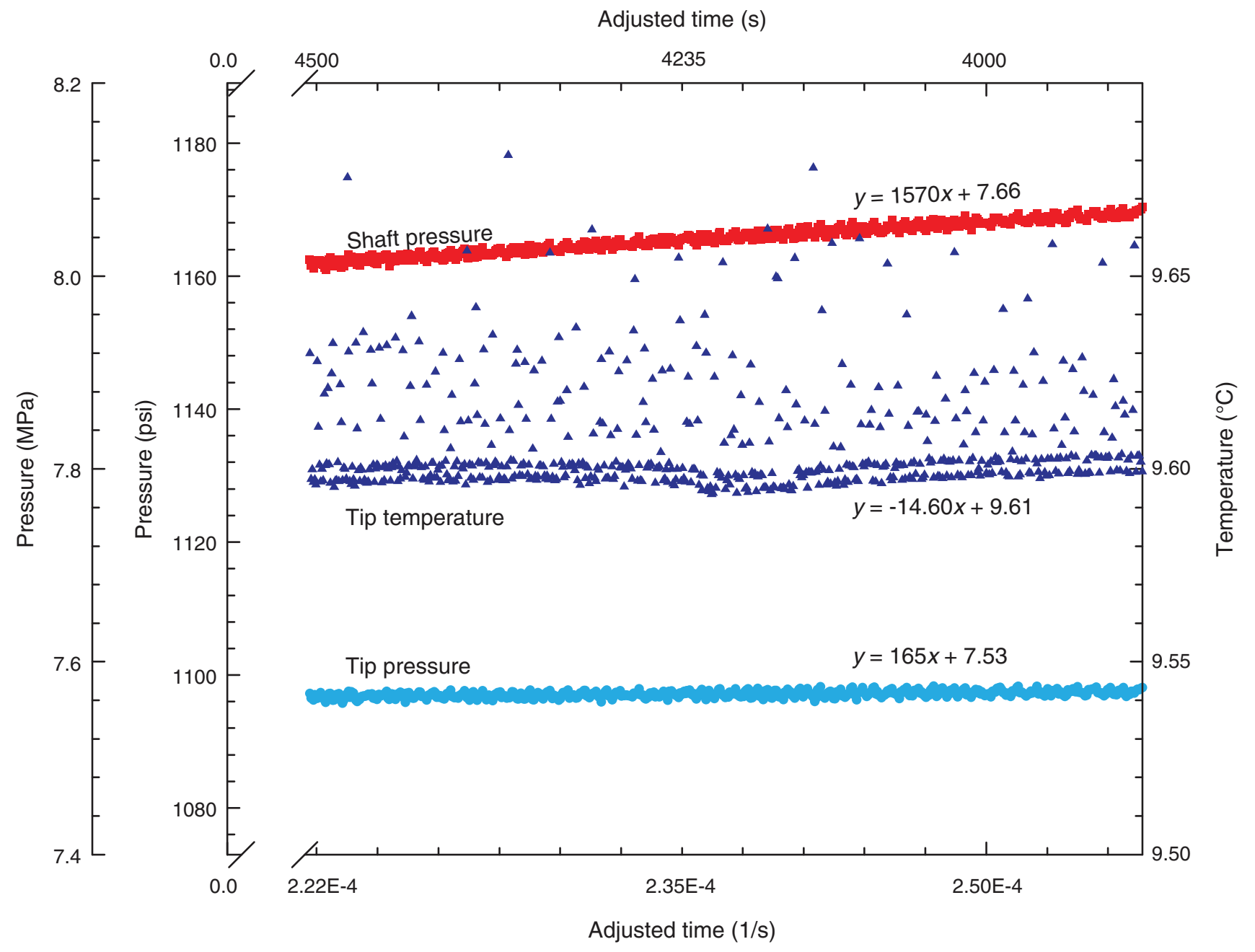


Figure F40. Plot of pressure vs. depth, Site U1402. The hydrostatic pressure is calculated assuming a fluid density of $1.019 \mathrm{~g} / \mathrm{cm}^{3}$ based on the pressure measurement at the mudline in the penetrometer. The overburden stress is calculated from integrating bulk density data from ODP Site 1073. Pressure plotted is the extrapolated tip pressure (see Fig. F39). The overpressure ratio $\left(\lambda^{*}\right)$ is equal to 0.2 . Overpressure is $20 \%$ of the difference between the overburden and the hydrostatic pressure.

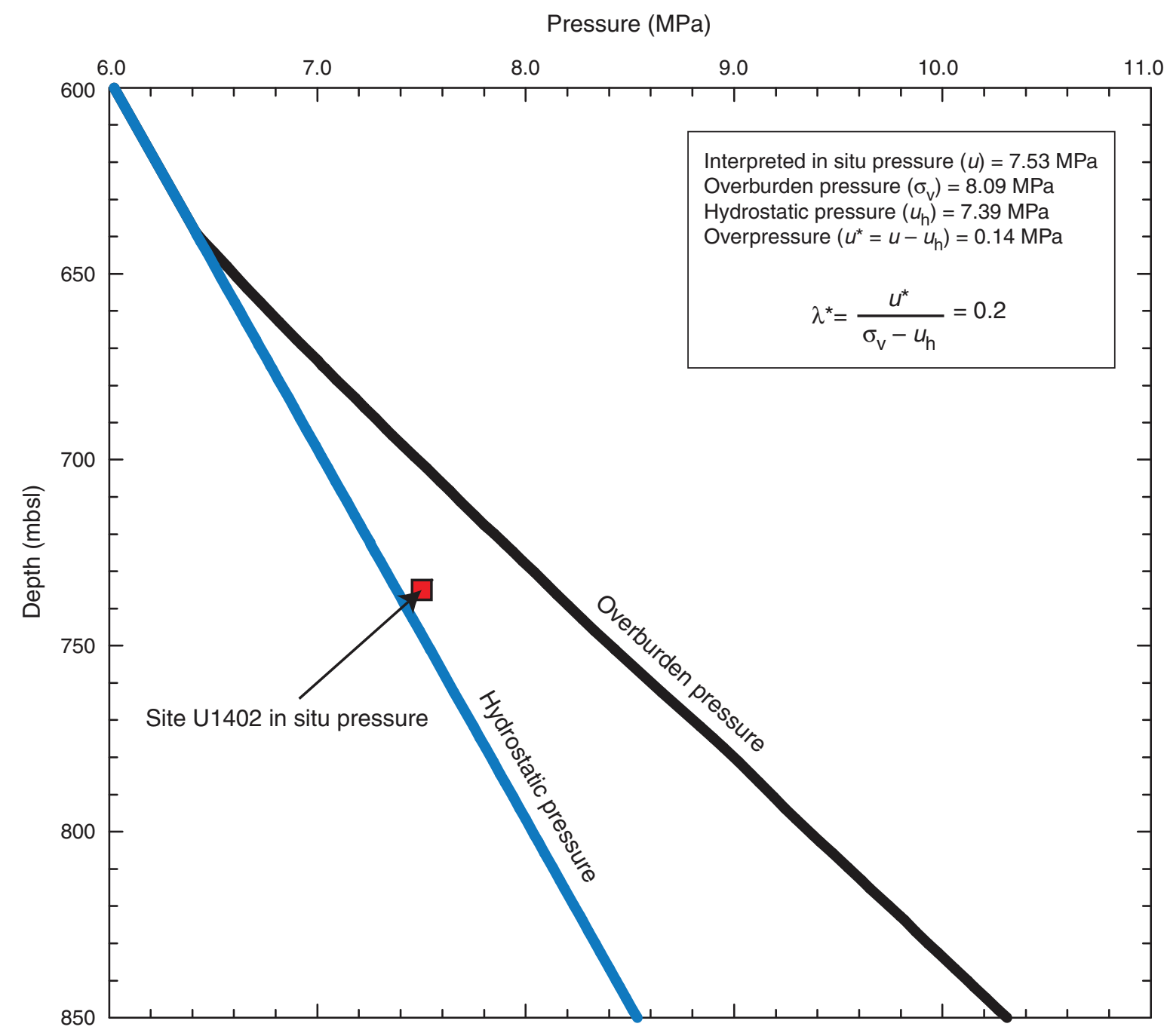


Figure F41. Diagram of the redesigned inner barrel subassembly as an inner rod subassembly. After Expedition 342 , it was decided not to use real-time telemetry.

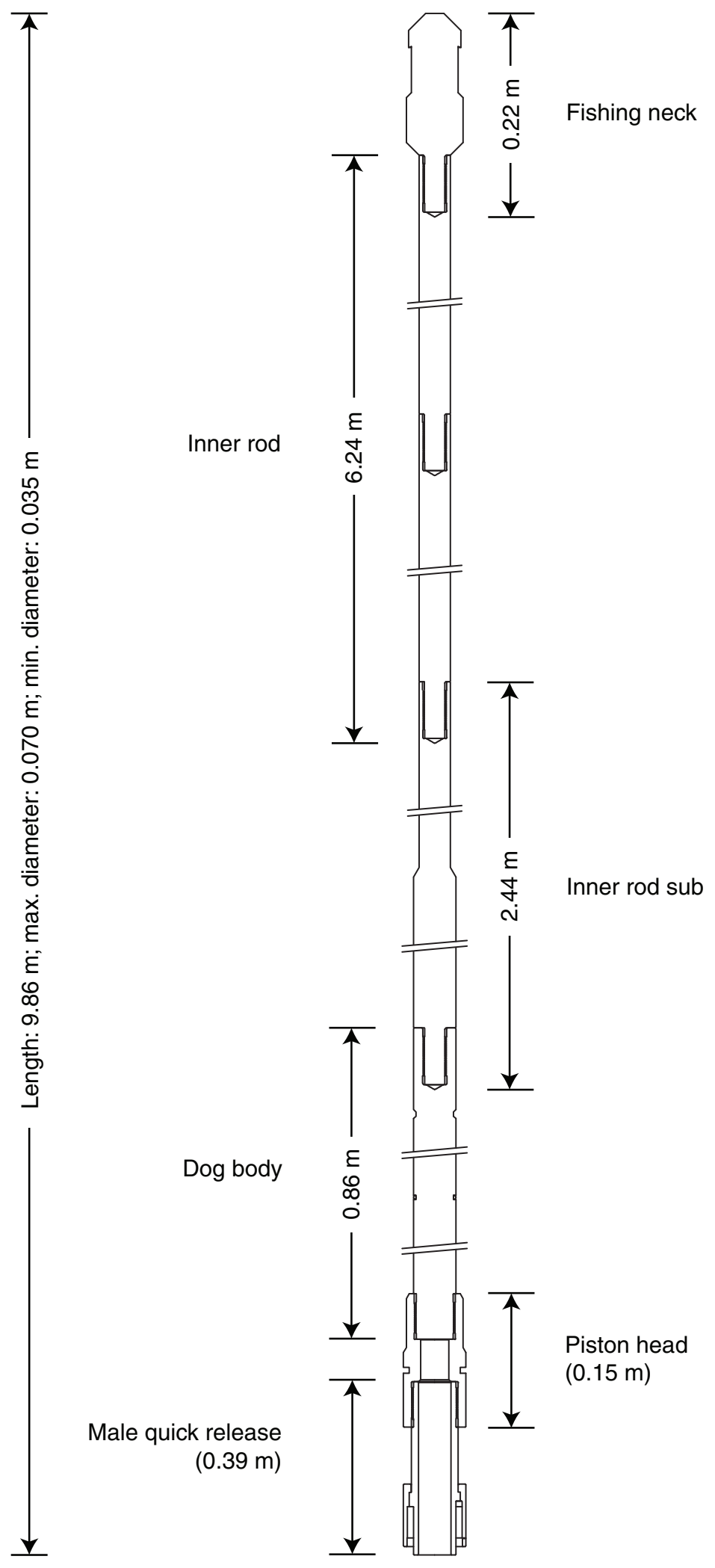


Table T1. Coring summary, Site U1402.

\begin{tabular}{|c|c|c|c|c|c|c|c|c|c|c|}
\hline \multirow[b]{2}{*}{ Core } & \multirow[b]{2}{*}{$\begin{array}{l}\text { Date } \\
\text { (2012) }\end{array}$} & \multirow[b]{2}{*}{$\begin{array}{l}\text { Time } \\
\text { UTC } \\
\text { (h) }\end{array}$} & \multicolumn{2}{|c|}{ Depth DSF $(m)$} & \multirow[b]{2}{*}{$\begin{array}{l}\text { Interval } \\
\text { cored } \\
(\mathrm{m})\end{array}$} & \multirow[b]{2}{*}{$\begin{array}{l}\text { Curated } \\
\text { length } \\
(\mathrm{m})\end{array}$} & \multicolumn{2}{|c|}{ Depth CSF-A (m) } & \multirow[b]{2}{*}{$\begin{array}{c}\text { Recovery } \\
\text { (\%) }\end{array}$} & \multirow[b]{2}{*}{$\begin{array}{l}\text { Sections } \\
(N)\end{array}$} \\
\hline & & & $\begin{array}{l}\text { Top of } \\
\text { drilled } \\
\text { interval }\end{array}$ & $\begin{array}{l}\text { Bottom } \\
\text { of drilled } \\
\text { interval }\end{array}$ & & & $\begin{array}{c}\text { Top of } \\
\text { core }\end{array}$ & $\begin{array}{l}\text { Bottom of } \\
\text { core }\end{array}$ & & \\
\hline \multirow[t]{2}{*}{$\begin{array}{l}342-U 1402 A \\
11\end{array}$} & 7 Jun & 2000 & \multicolumn{8}{|c|}{${ }^{* \star * \star}$ Drilled from 0.0 to $96.4 \mathrm{~m} \mathrm{DSF}{ }^{\star * \star *}$} \\
\hline & & & & Totals: & 0 & 0.00 & & & 0 & 0 \\
\hline \multicolumn{11}{|c|}{ 342-U1402B- } \\
\hline $1 \mathrm{H}$ & 8 Jun & 0930 & 0.0 & 7.0 & 7.00 & 7.02 & 0.00 & 7.02 & 100 & 6 \\
\hline \multirow[t]{3}{*}{$2 \mathrm{H}$} & 8 Jun & 1015 & 7.0 & 15.0 & 8.03 & 8.03 & 7.00 & 15.03 & 100 & 7 \\
\hline & & & & Totals: & 15.03 & 15.05 & & & 100 & 13 \\
\hline & & & \multicolumn{2}{|c|}{ Site U1402 totals: } & 111.40 & 15.05 & & & 100 & 13 \\
\hline
\end{tabular}

DSF = drilling depth below seafloor, CSF-A = core depth below seafloor, method $\mathrm{A} . \mathrm{H}=$ advanced piston core, numeric core type $=$ drilled interval.

Table T2. Benthic foraminifer distribution, Site U1402.

\begin{tabular}{|c|c|c|c|c|c|c|c|c|c|c|c|c|c|c|}
\hline $\begin{array}{l}\text { Core, section, } \\
\text { interval }(\mathrm{cm})\end{array}$ & $\begin{array}{l}\text { Depth } \\
\text { (mbsf) }\end{array}$ & 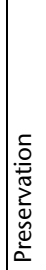 & 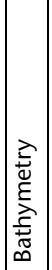 & 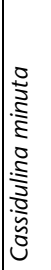 & 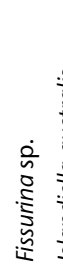 & 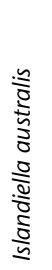 & 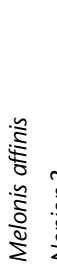 & 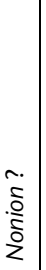 & 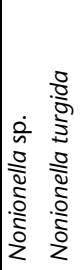 & 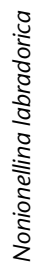 & 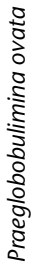 & 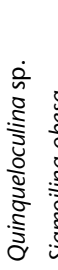 & 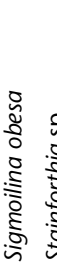 & \\
\hline $\begin{array}{r}342-\mathrm{U} 1402 \mathrm{~B}- \\
1 \mathrm{H}-\mathrm{CC}, 0-5 \\
2 \mathrm{H}-\mathrm{CC}, 0-5\end{array}$ & $\begin{array}{r}7.00 \\
14.24\end{array}$ & $\begin{array}{l}\text { VG } \\
\text { VG }\end{array}$ & $\begin{array}{l}\text { UB } \\
\text { UB }\end{array}$ & $\begin{array}{l}\text { D } \\
\text { A }\end{array}$ & P & $\begin{array}{l}D \\
D\end{array}$ & $\mathrm{~F}$ & $\begin{array}{l}A \\
F\end{array}$ & $F$ & $\begin{array}{l}F \\
F\end{array}$ & $P$ & $\begin{array}{l}P \\
F\end{array}$ & $P$ & \\
\hline
\end{tabular}

Preservation: $V G=$ very good. Bathymetry: $U B=$ upper bathyal. Abundance: $D=$ dominant, $A=$ abundant, $F=$ frequent, $P=$ present.

Table T3. Summary of AF demagnetization results for discrete samples, Hole U1402B.

\begin{tabular}{lrrcccc}
\hline $\begin{array}{c}\text { Core, section, } \\
\text { interval }(\mathrm{cm})\end{array}$ & $\begin{array}{c}\text { Depth } \\
(\mathrm{mbsf})\end{array}$ & $\begin{array}{c}\text { Declination } \\
20 \mathrm{mT} \text { or PCA } \\
\left({ }^{\circ}\right)\end{array}$ & $\begin{array}{c}\text { Inclination } \\
20 \mathrm{mT} \text { or PCA } \\
\left({ }^{\circ}\right)\end{array}$ & $\begin{array}{c}\text { PCA } \\
\text { MAD } \\
\left({ }^{\circ}\right)\end{array}$ & $\begin{array}{c}\text { PCA } \\
\text { range } \\
(\mathrm{mT})\end{array}$ & $\begin{array}{c}\text { NRM } \\
20 \mathrm{mT} \\
(\mathrm{A} / \mathrm{m})\end{array}$ \\
\hline 342-U1402B- & & & & & & \\
1H-1W, 75-77 & 0.76 & 106.7 & 45.7 & 6.1 & $10-60$ & $7.18 \mathrm{E}-03$ \\
1H-2W, 79-81 & 2.30 & 28.2 & 37.5 & & & $1.22 \mathrm{E}-03$ \\
1H-5W, 39-41 & 6.40 & 103.0 & 53.8 & 3.9 & $10-80$ & $9.18 \mathrm{E}-03$ \\
2H-2W, 75-77 & 8.13 & 4.8 & 47.1 & & & $5.09 \mathrm{E}-03$ \\
2H-3W, 75-77 & 9.50 & -150.2 & 57.4 & & & $8.48 \mathrm{E}-03$ \\
2H-4W, 61-63 & 10.80 & 30.1 & 65.6 & & & $4.73 \mathrm{E}-03$ \\
2H-5W, 75-77 & 12.33 & -113.4 & 52.5 & & & $8.39 \mathrm{E}-03$ \\
2H-6W, 55-57 & 13.62 & 165.4 & 68.8 & & & $4.94 \mathrm{E}-03$ \\
\hline
\end{tabular}

$\mathrm{PCA}=$ principal component analysis, $\mathrm{MAD}=$ maximum angle of deviation, $\mathrm{NRM}=$ natural remanent magnetization. 
Table T4. Summary of anisotropy of magnetic susceptibility of discrete samples, Hole U1402B.

\begin{tabular}{|c|c|c|c|c|c|c|c|c|c|c|c|c|c|c|c|}
\hline \multirow{2}{*}{$\begin{array}{l}\text { Core, section, } \\
\text { interval }(\mathrm{cm})\end{array}$} & \multirow{2}{*}{$\begin{array}{l}\text { Depth } \\
\text { (mbsf) }\end{array}$} & \multirow[b]{2}{*}{$\tau_{3}$} & \multicolumn{2}{|c|}{$V_{3}\left(^{\circ}\right)$} & \multirow[b]{2}{*}{$\tau_{2}$} & \multicolumn{2}{|c|}{$V_{2}\left({ }^{\circ}\right)$} & \multirow[b]{2}{*}{$\tau_{1}$} & \multicolumn{2}{|c|}{$V_{1}\left({ }^{\circ}\right)$} & \multirow{2}{*}{$\begin{array}{c}\text { Bulk } \\
\text { susceptibility } \\
\text { (SI) }\end{array}$} & \multirow{2}{*}{$\begin{array}{l}\text { Anisotropy } \\
\text { (\%) }\end{array}$} & \multirow[b]{2}{*}{$P$} & \multirow[b]{2}{*}{$\mathrm{L}$} & \multirow[b]{2}{*}{$\mathrm{F}$} \\
\hline & & & Declination & Inclination & & Declination & Inclination & & Declination & Inclination & & & & & \\
\hline \multicolumn{16}{|l|}{ 342-U1402B- } \\
\hline $1 \mathrm{H}-1 \mathrm{~W}, 75-77$ & 0.76 & 0.3229 & 6.4 & 67.9 & 0.3352 & 168.8 & 21.2 & 0.3419 & 261.1 & 6.1 & $4.16 \mathrm{E}-04$ & 1.9 & 1.059 & 1.020 & 1.038 \\
\hline $1 \mathrm{H}-2 \mathrm{~W}, 79-81$ & 2.30 & 0.3315 & 311.0 & 57.0 & 0.3331 & 152.4 & 31.1 & 0.3355 & 56.5 & 9.8 & $2.53 \mathrm{E}-04$ & 0.4 & 1.012 & 1.007 & 1.005 \\
\hline $1 \mathrm{H}-5 \mathrm{~W}, 39-41$ & 6.40 & 0.3260 & 205.3 & 72.1 & 0.3354 & 332.3 & 11.0 & 0.3385 & 65.1 & 13.9 & $3.18 \mathrm{E}-04$ & 1.3 & 1.038 & 1.009 & 1.029 \\
\hline $2 \mathrm{H}-2 \mathrm{~W}, 75-77$ & 8.13 & 0.3233 & 155.6 & 28.0 & 0.3350 & 356.7 & 60.3 & 0.3417 & 250.5 & 9.1 & $2.57 \mathrm{E}-04$ & 1.8 & 1.057 & 1.020 & 1.036 \\
\hline $2 \mathrm{H}-3 \mathrm{~W}, 75-77$ & 9.50 & 0.3209 & 155.7 & 86.6 & 0.3385 & 273.0 & 1.5 & 0.3406 & 3.1 & 3.0 & $3.05 \mathrm{E}-04$ & 2.0 & 1.062 & 1.006 & 1.055 \\
\hline $2 \mathrm{H}-4 \mathrm{~W}, 61-63$ & 10.80 & 0.2966 & 140.1 & 76.6 & 0.3332 & 307.2 & 13.1 & 0.3702 & 37.9 & 2.9 & $4.29 \mathrm{E}-04$ & 7.4 & 1.248 & 1.111 & 1.124 \\
\hline $2 \mathrm{H}-5 \mathrm{~W}, 75-77$ & 12.33 & 0.3195 & 139.3 & 86.4 & 0.3378 & 269.7 & 2.4 & 0.3427 & 359.8 & 2.8 & $3.34 \mathrm{E}-04$ & 2.3 & 1.073 & 1.015 & 1.057 \\
\hline $2 \mathrm{H}-6 \mathrm{~W}, 55-57$ & 13.62 & 0.3150 & 80.8 & 80.4 & 0.3414 & 293.1 & 8.2 & 0.3436 & 202.4 & 5.1 & $3.05 \mathrm{E}-04$ & 2.9 & 1.091 & 1.006 & 1.084 \\
\hline
\end{tabular}

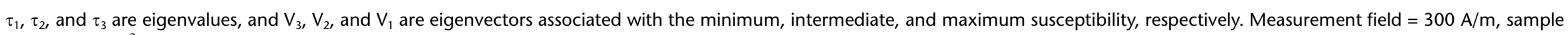
volume $=7 \mathrm{~cm}^{3} . P=$ degree of anisotropy, $\mathrm{L}=$ lineation, $\mathrm{F}=$ foliation.

Table T5. Geochemistry of headspace gas sample, Hole U1402B.

\begin{tabular}{ccc}
\hline $\begin{array}{c}\text { Core, section, } \\
\text { interval }(\mathrm{cm})\end{array}$ & $\begin{array}{c}\text { Depth } \\
(\mathrm{mbsf})\end{array}$ & $\begin{array}{c}\text { Methane } \\
(\mathrm{ppmv})\end{array}$ \\
\hline $\begin{array}{c}\text { 342-U1402B- } \\
1 \mathrm{H}-4,0-5\end{array}$ & 4.5 & 4.82 \\
\hline
\end{tabular}

Table T6. Interstitial water geochemistry, Hole U1402B.

\begin{tabular}{|c|c|c|c|c|c|c|c|c|c|c|c|}
\hline $\begin{array}{l}\text { Core, section, } \\
\text { interval }(\mathrm{cm})\end{array}$ & $\begin{array}{l}\text { Depth } \\
\text { (mbsf) }\end{array}$ & $\begin{array}{l}\text { Alkalinity } \\
(\mathrm{mM})\end{array}$ & $\begin{array}{l}\text { Ammonium } \\
(\mu \mathrm{M})\end{array}$ & $\begin{array}{c}\text { Calcium } \\
(\mathrm{mM})\end{array}$ & $\begin{array}{c}\text { Chloride } \\
\text { (mM) }\end{array}$ & $\begin{array}{l}\text { Magnesium } \\
(\mathrm{mM})\end{array}$ & $\mathrm{pH}$ & $\begin{array}{l}\text { Potassium } \\
\quad(\mathrm{mM})\end{array}$ & Salinity & $\begin{array}{l}\text { Sodium } \\
\text { (mM) }\end{array}$ & $\begin{array}{l}\text { Sulfate } \\
\text { (mM) }\end{array}$ \\
\hline $\begin{array}{l}42-\mathrm{U} 1402 \mathrm{~B}- \\
1 \mathrm{H}-3,140-150\end{array}$ & 3.00 & 13.77 & & & 555.57 & 43.87 & 7.717 & 1137 & 35 & 501.48 & 908 \\
\hline
\end{tabular}


Table T7. Sediment geochemistry, Hole U1402B.

\begin{tabular}{lrccccc}
\hline $\begin{array}{c}\text { Core, section } \\
\text { interval (cm) }\end{array}$ & $\begin{array}{c}\text { Depth } \\
\text { (mbsf) }\end{array}$ & $\begin{array}{c}\text { Calcium } \\
\text { carbonate } \\
\text { (wt\%) }\end{array}$ & $\begin{array}{c}\text { Inorganic } \\
\text { carbon } \\
\text { (wt\%) }\end{array}$ & $\begin{array}{c}\text { Total } \\
\text { carbon } \\
\text { (wt\%) }\end{array}$ & $\begin{array}{c}\text { Nitrogen } \\
\text { (wt\%) }\end{array}$ & $\begin{array}{c}\text { TOC } \\
\text { (wt\%) }\end{array}$ \\
\hline 342-U1402B- & & & & & & \\
1H-1, 116-118 & 1.16 & 2.524 & 0.303 & 2.06 & 0.08 & 1.76 \\
1H-2, 116-118 & 2.66 & 1.874 & 0.225 & 2.17 & 0.1 & 1.95 \\
1H-5, 75-77 & 6.75 & 2.201 & 0.264 & 2.46 & 0.11 & 2.2 \\
2H-2, 116-117 & 8.53 & 1.649 & 0.198 & 2.26 & 0.12 & 2.06 \\
$2 \mathrm{H}-3,93-94$ & 9.67 & 2.134 & 0.256 & 2.22 & 0.2 & 1.96 \\
$2 \mathrm{H}-4,113-114$ & 11.31 & 2.513 & 0.301 & 2.27 & 0.1 & 1.97 \\
$2 \mathrm{H}-5,113-114$ & 12.70 & 0.703 & 0.084 & 2.03 & 0.1 & 1.95 \\
$2 \mathrm{H}-6,76-77$ & 13.82 & 16.829 & 2.018 & 2.17 & 0.1 & 0.15 \\
\hline
\end{tabular}

TOC $=$ total organic carbon .

Table T8. Transit information of Motion Decoupled Hydraulic Delivery System (MDHDS) engineering personnel during sea trials, Site U1402.

\begin{tabular}{ll}
\hline $\begin{array}{c}\text { Date } \\
(2012)\end{array}$ & \multicolumn{1}{c}{ Event } \\
\hline 25, 26 May & MDHDS personnel arrive in Curaçao \\
28 May & Depart Curaçao \\
2 Jun & Arrive in Bermuda \\
4 Jun & Depart Bermuda \\
6 Jun & Arrive at Site U1402 \\
\hline
\end{tabular}

Table T9. Dates and times of important Motion Decoupled Hydraulic Delivery System (MDHDS) testing events during Deployment 1, Site U1402.

\begin{tabular}{ccl}
\hline $\begin{array}{c}\text { Date } \\
(2012)\end{array}$ & $\begin{array}{c}\text { Time } \\
(\mathrm{h})\end{array}$ & \\
\hline 6 Jun & 1542 & Arrive at Site U1402 \\
& 2300 & Drill string at $\sim 650 \mathrm{~m}$ DRF \\
7 Jun & 0115 & T2P data recording begins \\
& 0436 & MDHDS enters drill string \\
& 0450 & MDHDS detaches from ERS and falls to BHA \\
& 0504 & Data recording on T2P ceases \\
& 0751 & Multiple attempts to retrieve tool with ERS and fishing tool fail; begin tripping pipe out of hole \\
& 1100 & MDHDS recovered; begin tripping pipe into hole \\
\hline
\end{tabular}

Time is local ship time (Universal Time Coordinated $-3 \mathrm{~h}$ ). T2P $=$ temperature-dual-pressure probe, ERS $=$ electronic RS, BHA $=$ bottom-hole assembly. 
Table T10. Dates and times of important Motion Decoupled Hydraulic Delivery System (MDHDS) testing events during Deployment 2, Site U1402.

\begin{tabular}{lcl}
\hline $\begin{array}{c}\text { Date } \\
(2012)\end{array}$ & $\begin{array}{c}\text { Time } \\
(\mathrm{h})\end{array}$ & \multicolumn{1}{c}{ Event } \\
\hline 7 Jun & 1900 & Complete wash down to 96.4 m DRF \\
& 2115 & Deploy MDHDS \\
& 2239 & MDHDS unlatches, releasing T2P \\
& 2246 & MDHDS pressured up and T2P driven into formation \\
8 Jun & 0206 & Begin tripping pipe out of hole \\
& 0357 & MDHDS recovered \\
& 1010 & MDHDS personnel depart R/V JOIDES Resolution \\
& &
\end{tabular}

Time is local ship time (Universal Time Coordinated $-3 \mathrm{~h}$ ). T2P = temperature-dual-pressure probe.

Table T11. Detailed listing of Motion Decoupled Hydraulic Delivery System (MDHDS) events during Deployment 2, Site U1402.

\begin{tabular}{|c|c|c|c|c|c|}
\hline $\begin{array}{c}\text { Date } \\
\text { (2012) }\end{array}$ & $\begin{array}{l}\text { Time } \\
\text { (h) }\end{array}$ & $\begin{array}{l}\text { Elapsed } \\
\text { time (s) }\end{array}$ & $\begin{array}{l}\text { Adjusted } \\
\text { time (s) }\end{array}$ & Label & Event \\
\hline \multirow[t]{10}{*}{7 Jun } & 215406 & 0 & $-3,358$ & A & Begin data collection \\
\hline & 221140 & 1,054 & $-2,304$ & B & Tool rests at $285 \mathrm{~m} \mathrm{DRF}$ \\
\hline & 222223 & 1,697 & $-1,661$ & C & Tool rests at $645 \mathrm{~m}$ DRF (approximate mudline) \\
\hline & 222628 & 1,942 & $-1,416$ & D & Tool at BHA \\
\hline & 223406 & 2,400 & -958 & $\mathrm{E}(1)$ & Pressurize standpipe to unlatch; first attempt \\
\hline & 223702 & 2,576 & -782 & $E(2)$ & Pressurize standpipe to unlatch; second attempt \\
\hline & 223912 & 2,760 & -598 & $\mathrm{E}(3)$ & Pressurize standpipe to unlatch; third attempt \\
\hline & 224626 & 3,140 & -218 & $\mathrm{~F}$ & Pressurize standpipe; drive tool into formation \\
\hline & 225004 & 3,358 & 0 & G & Circulation terminated \\
\hline & 232644 & 5,558 & 2,200 & $\mathrm{H}$ & Communications tether severed \\
\hline \multirow[t]{4}{*}{8 Jun } & 000534 & 7,888 & 4,530 & I & First series of attempts to remove tool (using BHA and wireline) \\
\hline & 001404 & 8,398 & 5,040 & J & Second series of attempts to remove tool (using wireline) \\
\hline & 021159 & 15,473 & 12,115 & $\mathrm{~K}$ & Begin tripping pipe \\
\hline & 035717 & 21,791 & 18,433 & L & MDHDS at surface \\
\hline
\end{tabular}

Elapsed time refers to a $t=0$ of the start of temperature-dual-pressure probe (T2P) data recording, and adjusted time refers to a $t=0$ of the start of pressure and temperature dissipation after the circulation pumps had been turned off. Letters in the Label column refer to the events in the last column and in Figures F33, F34, F35, F36, F37, and F38. BHA = bottom-hole assembly. 